\title{
UICN
}

Diretrizes de biodiversidade para avaliações de oportunidades de restauração da paisagem florestal

Craig R. Beatty, Neil A. Cox e Mirjam E. Kuzee Primeira edição

União Internacional para a Conservação da Natureza

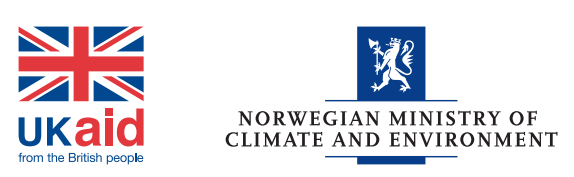





\section{Diretrizes de biodiversidade para avaliações de oportunidades de restauração da paisagem florestal}

Craig R. Beatty, Neil A. Cox e Mirjam E. Kuzee

Primeira edição 
A designação de entidades geográficas neste livro e a apresentação do material não implicam a expressão de qualquer opinião por parte da UICN sobre o estatuto legal de qualquer país, território ou área, ou das suas autoridades, ou sobre a delimitação das suas fronteiras ou limites.

As opiniões expressas nesta publicação não refletem necessariamente as opiniões da UICN.

A publicação deste material foi possível graças ao programa KNOWFOR, financiado pelo auxílio financeiro do governo do Reino Unido e pelo Ministério Norueguês do Clima e do Meio Ambiente.

A UICN e as outras organizações participantes não assumem a responsabilidade por erros ou omissões que possam ter ocorrido na tradução para o português deste documento, cuja versão original é na língua inglesa. Em caso de discrepâncias, é favor consultar a versão original. Título da versão original: Biodiversity guidelines for forest landscape restoration opportunities assessments. First edition. (2018). Publicado por: UICN, Gland, Suíça.

Publicado por: UICN, Gland, Suíça.

Copyright: @ 2018 UICN, União Internacional para a Conservação da Natureza.

A reprodução desta publicação para fins educacionais ou outros fins não comerciais é autorizada sem permissão prévia por escrito do detentor dos direitos autorais, desde que a fonte seja totalmente referenciada.

É proibida a reprodução desta publicação para venda ou outros fins comerciais sem a permissão prévia por escrito do detentor dos direitos autorais.

Citação: $\quad$ Beatty, C.R., Cox, N. A., e M. E. Kuzee (2018). Diretrizes de biodiversidade para avaliações de oportunidades de restauração da paisagem florestal. Primeira edição. Gland, Suíça: UICN. v + 43pp.

ISBN: $\quad$ 978-2-8317-1926-9 (PDF)

DOI: $\quad$ https://doi.org/10.2305/IUCN.CH.2018.10.pt

Foto da capa: Os Soliga são tribos indígenas das Montanhas Biligiri Rangana, no sul da Índia, e podem estar entre os primeiros colonos humanos daquele país. Como um povo dependente da floresta, os Soliga utilizam principalmente plantas silvestres na sua alimentação, em especial um prato feito de Kaddisoppu (Jasminum trichotomum), uma planta endémica da floresta seca decídua (não aparece na imagem). Foto cedida por Oxlaey

Traduzido por: Adriana Francisco e Richard Sanchez

Layout: $\quad$ www.chadiabi.com

Disponível em: UICN (União Internacional para a Conservação da Natureza)

Programa Global de Florestas e Mudanças Climáticas

Rue Mauverney 28

1196 Gland

Suíça

Tel +41229990000

Fax +41229990002

Craig.Beatty@iucn.org

www.iucn.org/resources/publications 


\section{Sumário}

Agradecimentos

Resumo executivo

\section{- Parte um}

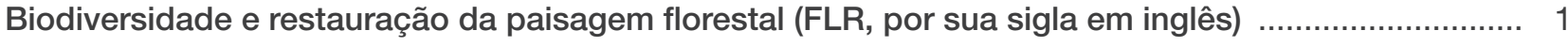

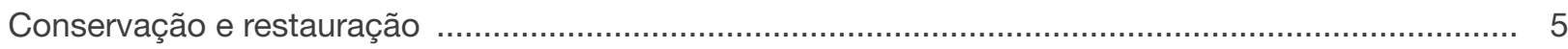

Biodiversidade genética para restauração da paisagem florestal .................................................... 5

Biodiversidade de espécies e restauração da paisagem florestal ..................................................... 5

Restauração da paisagem florestal e ecossistemas ....................................................................... 7

\section{- Parte dois}

Biodiversidade no planeamento de avaliações de restauração da paisagem florestal ........................ 11

Envolvimento de profissionais da biodiversidade .......................................................................... 14

Monitorização do impacto da FLR na biodiversidade e nas comunidades ............................................ 15

Informação sobre biodiversidade para o processo de avaliação ........................................................ 17

Fontes de informação sobre biodiversidade ….......................................................................... 17

- Dados nacionais existentes sobre biodiversidade e contatos .................................................. 17

- Alguns dos principais conjuntos de dados nacionais sobre biodiversidade ................................ 17

Estratégia e Plano de Ação Nacionais para a Biodiversidade (EPANB) ……….................................. 18

- Informações relevantes sobre biodiversidade das EPANB ........................................................... 18

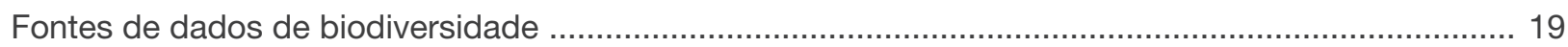

- Conjuntos de dados históricos ................................................................................................. 19

- Lugares e espécies culturalmente importantes ........................................................................ 20

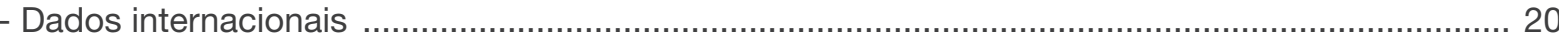

Políticas e informação institucional sobre biodiversidade .............................................................. 22

Dados de biodiversidade em mapeamento e análise espacial .......................................................... 24

Identificação das lacunas de biodiversidade .................................................................................. 27

Consideração da biodiversidade em avaliações e planeamento de FLR ............................................. 27

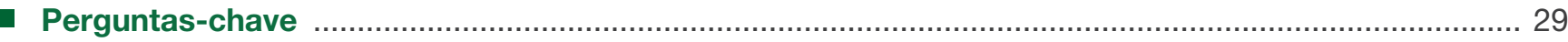

- Comunicando de forma eficaz a biodiversidade ................................................................................ 35

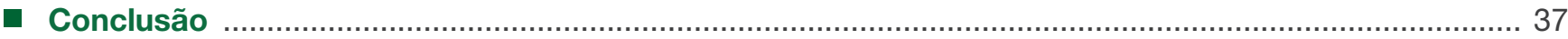

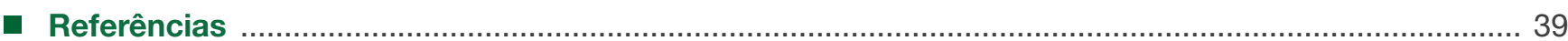

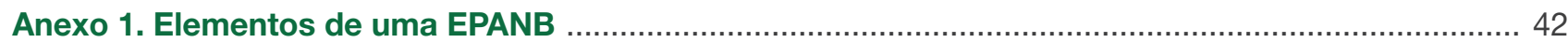




\section{Agradecimentos}

Esta publicação representa uma base para incentivar o reconhecimento mais amplo do valor da inclusão de informações sobre biodiversidade em avaliações de oportunidades de restauração da paisagem florestal e na implementação de ações de restauração. Este trabalho não poderia ter sido concluído sem o generoso apoio do Departamento para o Desenvolvimento Internacional do Reino Unido, no âmbito do Programa Conhecimento sobre Florestas.

Swati Hingorani forneceu orientação e apoio excepcionais durante o início e a elaboração destas diretrizes. Agradecemos muito também a Chetan
Kumar, a Salome Begeladze, a James McBreen, a Adriana Vidal e a Carole Saint-Laurent, pela suas recomendações construtivas à medida que a publicação se desenvolvia.

Os autores apreciam o incentivo oferecido por JeanChristophe Vié (ex-Programa de Espécies Globais e Principais Áreas de Biodiversidade da UICN) e Frank Hawkins (Escritório da UICN em Washington DC), especialmente durante a concepção do projeto.

Também somos gratos aos esforços de dois revisores especializados que melhoraram muito estas diretrizes. 


\section{Resumo executivo}

A biodiversidade é inerente à restauração da paisagem florestal. À medida que iniciativas globais como o Desafio de Bonn e a Declaração de Nova York sobre Florestas inspiram as nações a procurar paisagens sustentáveis e crescimento económico locais, a biodiversidade une as pessoas e a natureza ao seu futuro compartilhado. "Avançar" a restauração para enfrentar os desafios atuais e futuros da paisagem requer novas abordagens e soluções baseadas na natureza. A restauração tem o potencial de gerar biliões em retornos económicos e de mitigar muitos dos efeitos da mudança climática induzida pelo homem. Mas, na sua essência, a restauração deve dar apoio à biodiversidade e às espécies, genes e ecossistemas dos quais ela é composta e que prestam serviços direta ou indiretamente às pessoas.

Estas Diretrizes da biodiversidade para avaliações de oportunidades de restauração da paisagem florestal têm como objetivo fornecer mais contexto, mais recursos e novas perspectivas para a interação global contínua entre a conservação da biodiversidade e a restauração da paisagem florestal. Elas fazem-no no contexto da metodologia usada por dezenas de países e jurisdições para ajudar os profissionais a identificar e realizar as suas metas de restauração da paisagem - e devem ser interpretadas como um complemento da Metodologia de Avaliação de Oportunidades de Restauração (ROAM, por sua sigla em inglês).

Entre o Desafio de Bonn, a Convenção sobre Diversidade Biológica, os Objetivos de Desenvolvimento Sustentável e dezenas de outras iniciativas internacionais, regionais e nacionais, a conservação e restauração da biodiversidade continua a ser um precursor constante e claro da prosperidade social e económica de longo prazo. As iniciativas de biodiversidade e restauração têm, até recentemente, trabalhado em paralelo para alcançar muitos dos mesmos objetivos, e as diretrizes a seguir ajudarão aqueles com responsabilidade por, ou interesse em, biodiversidade ou restauração a alinhar os seus vocabulários e trabalho.

A primeira secção descreve o contexto e os princípios da restauração da paisagem florestal e explica brevemente as conexões entre a conservação da biodiversidade e a restauração da paisagem. Em seguida, debruça-se sobre os componentes genéticos, espécies e ecossistemas da biodiversidade e como eles se relacionam com a restauração da paisagem florestal, e inclui discussões sobre pontos de partida para mensurar a biodiversidade e a perspectiva de paisagem necessária para a restauração em escalas cada vez maiores. É importante ressaltar que ela fornece um ponto de partida necessário para aqueles que podem ver a restauração da paisagem florestal como um exercício de plantio de árvores e demonstra que uma abordagem abrangente, que equilibre as necessidades das pessoas e da natureza, vale bem o esforço.

A segunda secção fornece vários métodos de operacionalização da biodiversidade no processo de avaliação de restauração da paisagem florestal. $O$ que inclui fontes de informações e dados sobre biodiversidade, como identificar informações sobre biodiversidade onde elas parecem não existir, ideias iniciais sobre como mapear a biodiversidade e a importância de a considerar, não apenas de uma perspectiva biológica, mas também de políticas, leis e missões institucionais. Nessa secção, os leitores encontrarão uma riqueza de recursos e contactos para garantir que a falta de informação disponível não seja a razão pela qual a biodiversidade esteja ausente das suas avaliações.

Por fim, estas diretrizes destinam-se a ajudar os profissionais a traduzir e comunicar a importância do seu trabalho num contexto de biodiversidade e a ajudar a integrar a biodiversidade em outros setores. Espera-se que o resultado seja um processo de avaliação que identifique explicitamente opções para a escolha e interação entre espécies numa paisagem para produzir os benefícios biológicos, sociais e ecológicos que formam o propósito da restauração. As estratégias paisagísticas que resultam dessa inclusão explícita do conhecimento científico e tradicional da biodiversidade vão longe para garantir que os investimentos significativos feitos na restauração da paisagem florestal possam gerar retornos que sustentem a incrível diversidade da vida e da cultura. 


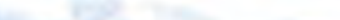

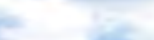

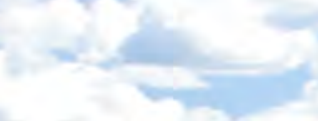

-

3in

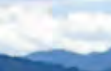

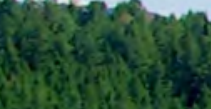

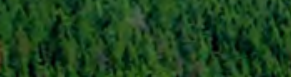
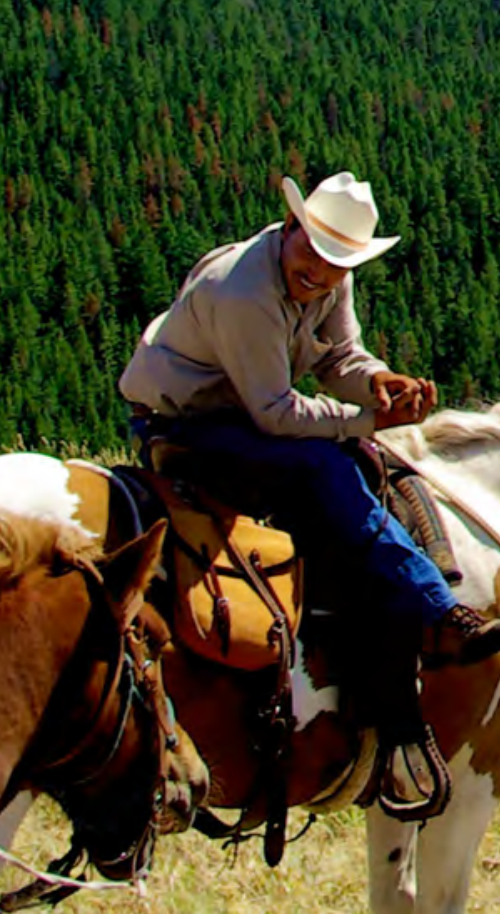

H.

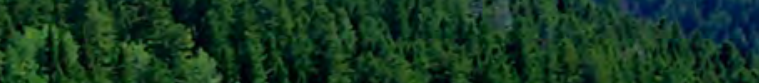

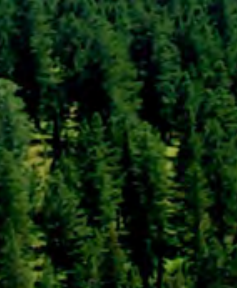
(5)

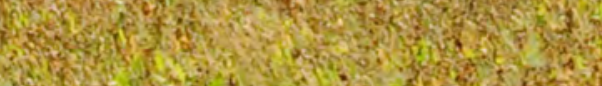

Win

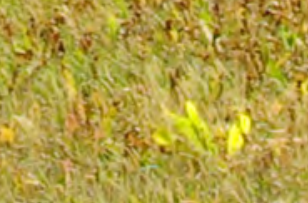

\section{Parte um}

\section{Biodiversidade}

e

restauração da paisagem florestal 
Restauração da Paisagem Florestal (FLR, por sua sigla em inglês) é o processo de longo prazo de recuperar a funcionalidade ecológica e melhorar o bem-estar humano em paisagens desmatadas e degradadas, e continua a ser uma iniciativa-chave para manter ou restaurar a biodiversidade. A FLR é implementado através da utilização de uma abordagem de paisagem que combina gestão de recursos naturais, oportunidades de restauração e considerações de meios desubsistênciaatravés de fronteiras jurisdicionais com o objetivo de restaurar um mosaico de usos da terra, incluindo florestas e áreas florestais, pastagens, plantações e muito mais. Em escala de paisagem, a restauração responde às necessidades da sociedade e permite a consideração de múltiplos benefícios dos serviços ecossistémicos para alimentação, nutrição e segurança hídrica; promove negócios locais e justiça social; apoia o desenvolvimento rural e as economias nacionais; e constrói resiliência a desastres e a mudanças climáticas.

A restauração de paisagens degradadas e desmatadas fornece serviços ecossistémicos essenciais de aprovisionamento (como alimentos, lenha e recursos genéticos); serviços de regulação (regulação climática, ciclagem de nutrientes e edificação do solo, regulação e purificação da água e polinização); serviços culturais (espirituais, religiosos, recreativos, educacionais e que contribuem para o estabelecimento de um sentido de lugar); e podem fornecer o habitat necessário para espécies ameaçadas, pois uma grande percentagem de espécies na Lista Vermelha de Espécies Ameaçadas da UICN está em risco por causa da perda ou degradação do habitat (Mace et al., 2005; UICN, 2018). Estes importantes serviços são normalmente sustentados pela riqueza biológica das paisagens, com evidências crescentes de que uma maior biodiversidade é

Restauração da Paisagem Florestal (FLR) é o processo de longo prazo de recuperação das funções ecológicas e melhoria do bem-estar humano em terras desmatadas e degradadas. Em última análise, a FLR é o processo de restaurar "os bens, serviços e processos ecológicos que as florestas podem fornecer num nível de paisagem mais amplo, em oposição a apenas promover o aumento da cobertura de árvores num local especifico" (Maginnis e Jackson, 2002).

A restauração da paisagem florestal baseia-se em vários princípios orientadores:

- Restaurar a funcionalidade - Restaurar a funcionalidade de uma paisagem, fazendo com que seja mais capaz de oferecer um habitat rico, prevenir erosão e enchentes e resistir aos impactos da mudança climática e de outras interferências.

- Foco na paisagem - Considerar e restaurar paisagens completas em vez de locais individuais. Normalmente, isso requer que haja um equilíbrio na combinação de usos agrários independentes, que incluem, entre outras funções: agricultura, áreas protegidas, sistemas agroflorestais, florestas plantadas bem geridas, corredores ecológicos, plantações ribeirinhas e áreas designadas para a regeneração natural.

- Permitir benefícios múltiplos - Ter como objetivo gerar uma gama de serviços ecossistémicos com a introdução inteligente e adequada de árvores e outras plantas lenhosas na paisagem. Isto pode envolver a plantação de árvores em terras agrícolas para melhorar a produção de alimentos, reduzir a erosão, fornecer sombra e produzir lenha; ou podem ser plantadas árvores para criar uma mata densa e fechada, que retém grandes quantidades de carbono, protege o abastecimento de água a jusante e fornece um rico habitat para a vida selvagem.

- Potenciar um conjunto de estratégias - Considerar uma vasta gama de estratégias técnicas possíveis, desde a regeneração natural até à plantação de árvores, para restaurar as paisagens florestais.

- Envolver intervenientes - Envolver intervenientes locais de forma ativa na decisão dos objetivos de restauração, do métodos de implementação e das compensações. Os processos de restauração devem respeitar os seus direitos à terra e aos recursos, devem estar alinhados às suas práticas de gestão da terra e devem proporcionar-lhes benefícios.

- Adaptar estratégias para as condições locais - Adaptar estratégias de restauração aos contextos sociais, económicos e ecológicos locais, pois não existe uma solução comum a todos.

- Evitar a redução adicional da cobertura florestal natural - Abordar a perda contínua e evitar conversões de florestas naturais primárias e secundárias e de outros ecossistemas.

- Gerir de forma adaptativa - Estar preparado para ajustar a estratégia de restauração ao longo do tempo, conforme as mudanças nas condições ambientais, no conhecimento e nos valores sociais. Incentivar um acompanhamento e aprendizagem contínuos e fazer ajustes conforme o progresso da restauração.

1. Os ecossistemas são reconhecidos por serem sistemas dinâmicos, e não estáticos. Assim, embora seja tipicamente incorreto usar o termo "estabilidade" em referência aos ecossistemas, nós mantemos o seu uso como um termo geral para guiar os leitores menos técnicos. 


\section{Soluções para um planeta cultivado}

\section{Fornecimento estável de água limpa através de revegetação ao longo de hidrovias}

\section{Captura e}

armazenagem de

carbono através de

maior vegetação e

solos
Diversidade

biológica através de

restauração sensível

à ecologia com

espécies nativas
Segurança

alimentar $\mathbf{e}$

nutrição através

da diversificação de

fontes de alimentos
Paisagens

resilientes através

de melhorias

da capacidade

adaptativa

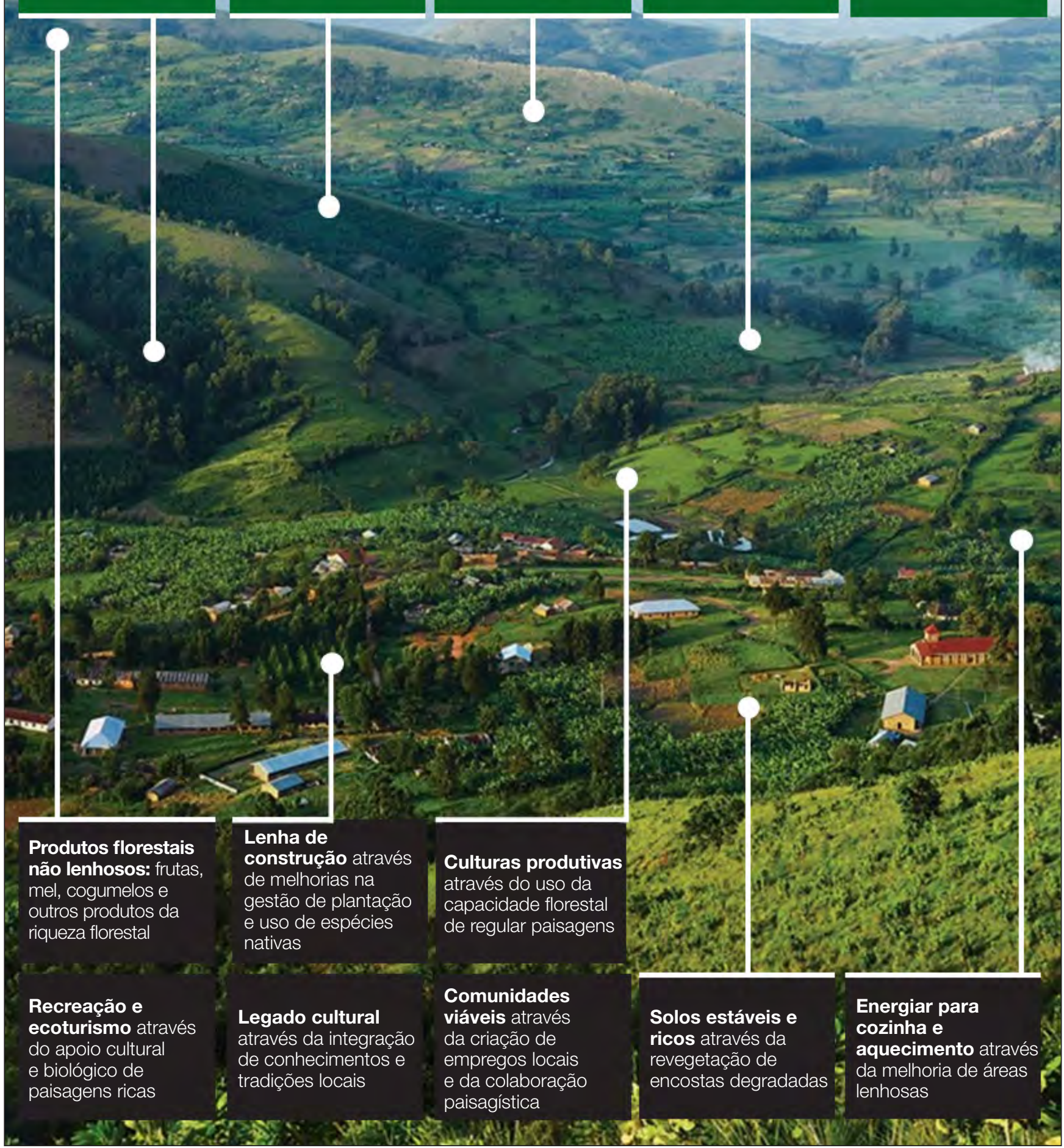


diretamente proporcional à quantidade (funções) e à "estabilidade" geral" (resiliência ambiental) dos serviços ecossistémicos prestados às pessoas (Hooper et al., 2005; Hooper et al. 2012; Cardinale et al., 2012; Larsen et al., 2012; Oliver et al., 2015a; Oliver et al., 2015b; Walker e Salt, 2006).

A FLR para conservação e restauração da biodiversidade pode ocorrer na maioria das paisagens. Em termos globais, as florestas abrigam mais de 75\% da biodiversidade terrestre (FAO, 2016) - e continuam a ser uma fonte significativa para a descoberta de muitas espécies ainda desconhecidas e não descritas. Numerosos animais e plantas são espécies florestais especializadas e não ocorrem fora desses habitats. Atualmente, a Lista Vermelha de Espécies Ameaçadas da UICN classifica aproximadamente $29 \%$ das espécies florestais avaliadas como em risco de extinção (UICN, 2018). A restauração de paisagens desmatadas e degradadas pode deter e reverter a extinção de espécies de várias maneiras. Além disso, o aumento do número de árvores e espécies em terras cultiváveis ou em sistemas silvipastoris pode formar solo e melhorar a disponibilidade de água para culturas em áreas de sequeiro; possibilitando estratégias de subsistência diversificadas que visam trazer de volta e conservar as árvores, ao mesmo tempo que aumentam a produção de culturas e gado.

Embora os benefícios da restauração da biodiversidade possam estar implícitos e serem importantes, a restauração da paisagem que aborda o bem-estar humano também resultará em benefícios sociais explícitos e mensuráveis quando a conservação e restauração da biodiversidade for um componente explícito do projeto, do planeamento e da avaliação do potencial de restauração da paisagem florestal - a sua "avaliação de oportunidade".

O objetivo desta publicação é oferecer ao praticante de FLR, ao planeador da restauração de paisagem e àqueles responsáveis pelas decisões, as diretrizes sobre como integrar melhor o conhecimento e os dados sobre biodiversidade nas oportunidades e avaliações de FLR e por que é que essa abordagem faz sentido. A intenção é fornecer orientação sobre como os profissionais podem operacionalizar um mandato ou um interesse em incluir explicitamente o conhecimento e as informações sobre a biodiversidade no processo de avaliação e planeamento da FLR. O documento a seguir descreve por que é que a biodiversidade deve ser incluída na FLR, algumas fontes comuns disponíveis de informações e dados sobre biodiversidade, o processo de comunicação de informações sobre biodiversidade nas avaliações da FLR e como podem ser formadas parcerias para melhor servir à conservação e à restauração da biodiversidade. O uso destas diretrizes é mais eficaz em conjunto com a Metodologia de Avaliação de Oportunidades de Restauração (ROAM, por sua sigla em inglês), publicada pela UICN em colaboração com o WRI (2014), que fornece uma estrutura mais abrangente do processo de avaliação da FLR e produtos analíticos típicos.

\section{Uma observação importante a respeito das bases de referência}

Há poucos lugares remanescentes no mundo onde as espécies não foram afetadas pela atividade humana. Com isso em mente, a diversidade e a abundância de espécies são tipicamente avaliadas a partir de uma compreensão atual (Antropoceno) de bases de referência ecológicas sobre o que é um nível aceitável de abundância de espécies e mudança na composição da comunidade ou estado de conservação de habitats e espécies.

No entanto, das cerca de 2 milhões de espécies descritas, apenas 87 mil foram avaliadas quanto ao seu estado de conservação pela UICN e ainda existem lacunas taxonómicas significativas na avaliação global do estado de conservação das espécies. Pouco ou nada se conhece sobre a diversidade e a abundância da maioria das espécies não vertebradas e, ainda assim, muitas delas formam a base de todos os ecossistemas. Apesar dessa falta de conhecimento, reduções drásticas na biodiversidade forçam os praticantes a utilizar os poucos detalhes que existem para deter o declínio da biodiversidade.

Os últimos 250 anos viram espécies em muitos lugares selvagens desaparecerem, com perdas significativas de espécies e habitats nos últimos 50 anos. O que hoje parece abundante pode estar bem abaixo dos níveis históricos da população. O que resta é um número cada vez maior de pessoas que dependem de um conjunto cada vez menor de espécies para fornecer os serviços sobre os quais as culturas, sociedades e economias humanas foram construídas e dos quais ainda dependem muito. O estabelecimento de bases de referência é fundamental e, sempre que possível, deve estruturar-se a partir da análise de tendências populacionais de espécies ou da extensão de habitats e ecossistemas adequados, especialmente porque podem ser afetados pelas mudanças climáticas. 


\section{Conservação e restauração}

Uma grande quantidade de literatura e produção científica é dedicada à conservação de espécies e ecossistemas estabelecidos. Muito menos é dedicado à restauração da biodiversidade em lugares onde ela diminuiu ou desapareceu substancialmente. A restauração da biodiversidade não é apenas a introdução de espécies e ecossistemas, é também a restauração ou conservação de processos que levam à biodiversidade. São processos ecológicos que criam e mantêm a biodiversidade. Para ser bem-sucedida, a restauração deve considerar e apoiar tanto o padrão quanto os processos de biodiversidade (Pressey et al., 2007). A literatura sobre restauração ecológica está a aumentar e, geralmente, o foco dessa disciplina, que ainda é jovem, é restaurar sistemas ecológicos degradados em direção a um ecossistema de referência ou trajetória sucessional (Young, 2000). Isso envolve apoio à reintrodução de espécies e processos ecológicos que, com o tempo, interagirão para criar ecossistemas restaurados ou guiarão as interações e reuniões de espécies para promover os estágios sucessionais desejados. A restauração em direção a um ecossistema de referência pode ser mais adequada para algumas paisagens e objetivos de restauração (por exemplo, reintrodução de espécies ou conservação), especialmente quando a motivação é restaurar áreas degradadas e desmatadas em direção à sua condição anterior. Para esses objetivos, a restauração ecológica é uma abordagem valiosa e necessária. Na FLR, a restauração ecológica constitui um componente valioso do conjunto de estratégias de restauração disponíveis para os seus praticantes. A FLR utiliza muitas ações restaurativas adicionais em paisagens para garantir que se concentra na integração de muitos objetivos e tipos de uso do solo sustentáveis, para abordar os vetores e as pressões que levaram à degradação em primeiro lugar.

A restauração da paisagem florestal envolve a recuperação, a longo prazo, da produtividade ecológica, baseada numa trajetória ecológica sustentável e biodiversa. Essa trajetória é construída sobre as interações entre os três principais componentes da biodiversidade: genes, espécies e ecossistemas das paisagens, mas na prática é frequentemente projetada fora de uma perspectiva ecológica. Desta forma, a diversidade genética, a diversidade de espécies e a diversidade de ecossistemas são, em avaliações e planos de restauração da paisagem florestal, frequentemente incorporadas em discussões sobre produtividade agrícola, resiliência de paisagem ou adaptabilidade à mudança climática. Embora cada uma delas seja um aspecto importante, no seu nível mais fundamental, cada uma depende dos bens e serviços fornecidos pelas espécies e das suas redes de interação dentro dos ecossistemas. A forma como os praticantes podem traduzir esses conceitos é o foco das secções que se seguem.

\section{Biodiversidade genética para restauração da paisagem florestal}

A diversidade genética de espécies é uma das considerações mais importantes na restauração da paisagem. Isto é tanto verdade para espécies agrícolas (por exemplo: espécies agroflorestais, cultivares e raças de gado), como também espécies nativas utilizadas em atividades de restauração. A diversidade genética confere maior proteção contra doenças e ajuda a garantir que os serviços ecossistémicos presentes na paisagem sejam resilientes às mudanças ambientais. A diversidade genética é a primeira linha de defesa na construção de paisagens resilientes e economias agrícolas e é a moeda de troca usada pelas espécies na sua capacidade de se adaptar e sobreviver às mudanças ambientais.

Assegurar que a diversidade genética intraespecífica da biomassa de restauração no interior da paisagem degradada a ser restaurada seja tão variada quanto possível (dentro dos limites dos recursos disponíveis), deve ser uma consideração importante no planeamento de estratégias de restauração. Se as monoculturas de indivíduos geneticamente quase idênticos ou clonados forem usadas para esforços de restauração, serão geralmente mais suscetíveis a danos ou perdas através de eventos estocásticos, como doenças ou endogamia. Uma paisagem ou habitat geneticamente mais diverso tem tipicamente uma probabilidade muito maior de conter indivíduos com resistência parcial ou total a um evento ameaçador (ver, por exemplo, Reusch et al., 2005).

Ao procurar indivíduos de espécies para o trabalho de restauração (especialmente sementes ou mudas), é útil tentar obter reservas da mesma origem, ou similar, para as populações que existem (ou existiam anteriormente) na paisagem a ser restaurada. Estes indivíduos geralmente são geneticamente mais bem adaptados às condições ambientais (como padrões climáticos locais) encontrados na paisagem, do que indivíduos provenientes de populações externas ou mais distantes. Se a prática de restauração for uma intervenção agroflorestal, será útil considerar também o uso ou a promoção de variedades de culturas locais (incluindo árvores) porque, da mesma forma que com plantas nativas de proveniência local, essas variedades locais são frequentemente mais bem adaptadas às condições ambientais locais e podem ter maior adaptabilidade a um clima em mudança.

\section{Biodiversidade de espécies e restauração da paisagem florestal}

Como unidade ecológica fundamental, as espécies são o meio pelo qual a diversidade genética e do ecossistemase irradia. Os procedimentos de avaliação e implementação para a restauração da paisagem correspondem a diferentes oportunidades para expressar a escolha das 
espécies a serem usadas nas atividades de restauração. A oportunidade de selecionar espécies para restauração é criada quando os praticantes identificam uma ação de restauração desejada, refinam a avaliação de como essa ação pode deter ou retardar a degradação da paisagem, estimam como a restauração pode aumentar a produtividade ecológica e determinam quando os planos de restauração se estabelecerão como plantas no solo.

Em paisagens dominadas pela agricultura, a escolha de diferentes espécies para uso na sua restauração dependerá de muitos fatores, incluindo tipos de culturas, rotações de culturas e questões agrícolas específicas que podem ser abordadas através da FLR. A seleção de espécies também pode ser usada para aumentar os serviços de polinização, para aumentar a biodiversidade e a fertilidade do solo, ou para aumentar a sombra e a forragem. Cada uma é uma decisão enraizada no conhecimento prático do praticante. Além disso, as espécies agroflorestais são geralmente selecionadas com base na sua disponibilidade, afinidade com as partes interessadas e praticidade económica, mas essas espécies também podem ter consequências ecológicas que devem ser identificadas, pesadas e abordadas pela equipa de avaliação da FLR em consulta a grupos de partes interessadas. Quando a diversidade genética for inexistente ou uma espécie agroflorestal tiver o potencial de se tornar uma espécie exótica invasora, uma avaliação cuidadosa, consultas e planeamento são necessários para determinar um equilíbrio aceitável de risco ecológico, nos casos em que ocorram tais casos.
No processo de restauração da paisagem florestal, independentemente do objetivo político ou social de tal restauração, há um potencial significativo para fazer escolhas de restauração que tenham impactos positivos sobre a biodiversidade nativa, em alguns casos até mesmo através do uso de espécies exóticas. A diversidade de abordagens de restauração da paisagem florestal numa paisagem garante que nenhum tipo único de restauração domine paisagens degradadas, mas que as soluções dependam do uso de uma diversidade de espécies e métodos para restauração. Algumas dessas espécies podem ser não nativas, mas são importantes para a subsistência e bem-estar humanos ou para a restauração de serviços ecossistémicos. Apesar dessa realidade, cada processo de paisagem e restauração deve, preferencialmente, incluir a restauração e/ou reintrodução de espécies nativas em algum momento do cronograma e paisagem planeados do projeto.

Além das razões gerais para uma avaliação de quais espécies utilizar na restauração, há alguns benefícios bem definidos e práticos para garantir que a conservação ou restauração de espécies em terras degradadas sejam consideradas durante o processo geral de planeamento de restauração da paisagem. Muitos desses benefícios estão associados à garantia de que as relações de espécies dentro de áreas restauradas melhorem a função ecológica da paisagem. O que inclui o restabelecimento de uma variedade de espécies-chave de polinizadores (por exemplo, abelhas nativas e morcegos) e agentes de dispersão de sementes (por exemplo, esquilos, casuares, tucanos) que interagem com as espécies de árvores

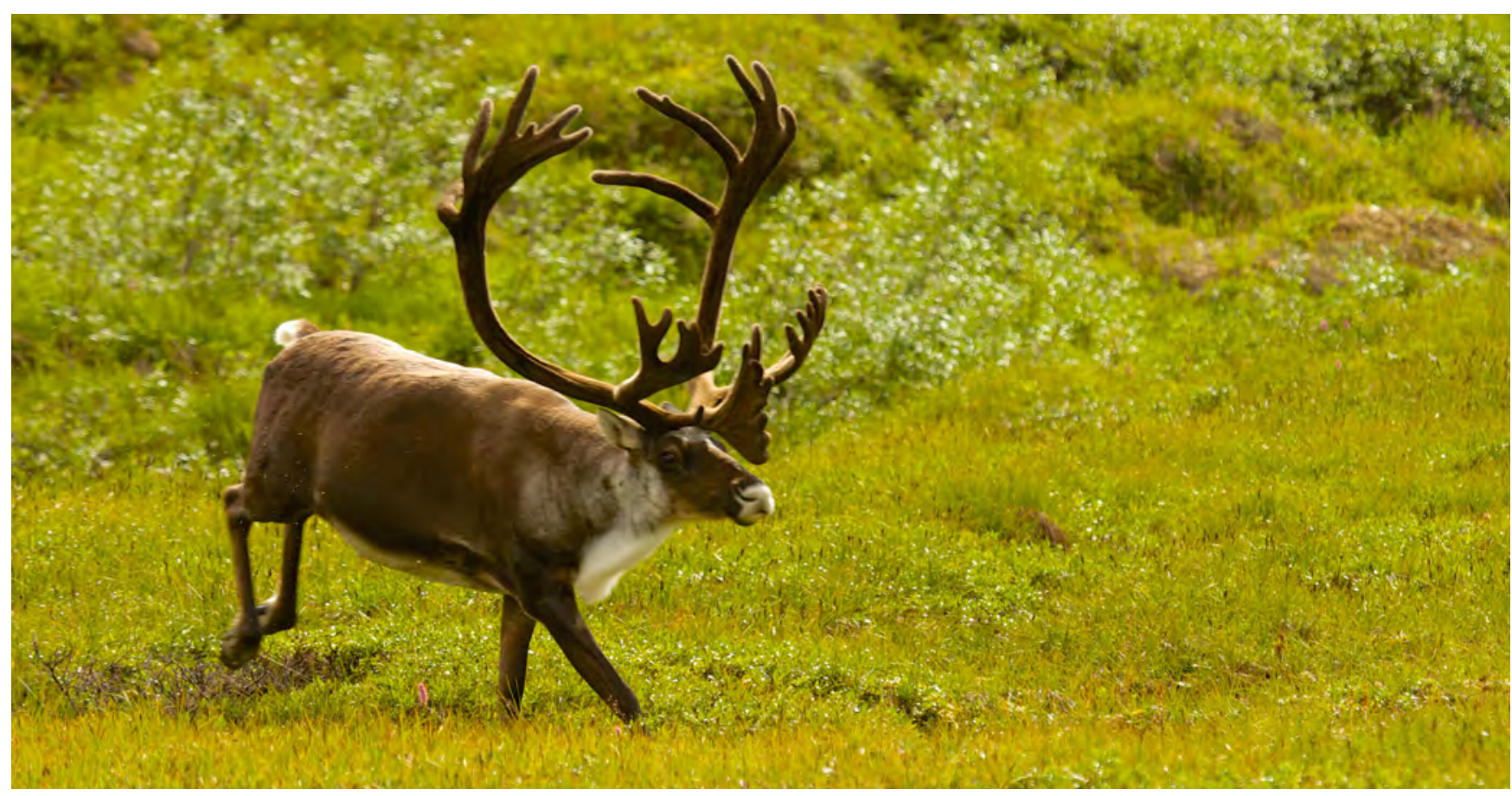

Entre as maiores iniciativas de recuperação de espécies únicas no mundo encontra-se esta do governo canadiano, que é encarregado de implementar a estratégia de recuperação para o caribu dos bosques (Rangifer tarandus caribou). Esta estratégia envolve muitas avaliações de oportunidades de restauração da paisagem para apoiar a implementação nacional, provincial e territorial. Foto cedida por Bill Bumgarner 
escolhidas para crescer dentro do local de restauração. Especialmente nas florestas tropicais, a polinização animal e a dispersão de sementes são fundamentais para manter e aumentar a diversidade florística na escala da paisagem.

No entanto, os habitats são complexos e incluem numerosas relações menos óbvias entre espécies no interior dos locais de restauração e espécies que precisam ser consideradas no processo de planeamento para melhorar a funcionalidade. Uma revisão da comunidade ecológica que existia (ou presumivelmente existia) no local antes da degradação, deve fornecer alguma orientação sobre espécies apropriadas, em cada nível trófico, que possam ser consideradas para a reintrodução/ restauração populacional dentro da área do projeto. É, no entanto, crítico que os ecossistemas de referência não formem toda a base do planeamento de restauração. A FLR visa não apenas dar apoio ao bem-estar humano, como também aumentar a produtividade ecológica, mas estas trajetórias de restauração podem-se complicar através da mudança climática que atualmente está a alterar as variedades de espécies e os modelos de adequação do habitat. Dessa forma, as comunidades e populações de plantas e animais atualmente respondem às mudanças nas condições climáticas e continuarão a fazê-lo para o futuro concebível. O que já existiu numa paisagem pode fornecer orientação sobre espécies que podem ser restauradas, mas um foco em características funcionais e cenários climáticos pode fornecer previsões mais precisas para as próximas décadas.

Ao considerar ou planear o restabelecimento de espécies, é sempre importante ter em mente os impactos, tanto positivos quanto negativos, que eles podem ter sobre os autóctones no interior do local do projeto e áreas adjacentes. Pode não ser prático, por exemplo, introduzir grandes predadores (como lobos) numa área onde eles podem frequentemente matar o gado. A UICN desenvolveu diretrizes claras para auxiliar no planeamento de reintroduções e translocações de espécies (UICN/CSE, 2013).

Por fim, a adequação das espécies a serem usadas ou esperadas em intervenções de restauração deve ser o resultado de um processo participativo entre setores e partes interessadas. Isto não aumenta apenas a probabilidade de que as espécies estejam a fornecer os benefícios funcionais desejados pelas partes interessadas e setores, mas também ajudará a aumentar a probabilidade de que as espécies usadas na restauração também respondam às necessidades de subsistência das pessoas que dependem da produtividade da paisagem.

\section{Restauração da paisagem florestal e ecossistemas}

A FLR deve funcionar em todas as paisagens e os usos do solo a elas associados. Essas paisagens inteiras e as interações entre os seus ecossistemas, não apenas a unidade específica do local ou do ecossistema, são o que impulsionam as ambições em larga escala da FLR. As escolhas de espécies e as interações esperadas entre elas devem ser direcionadas para maximizar os múltiplos benefícios das paisagens restauradas, tanto para pessoas quanto para paisagens. Em última instância, a escolha das espécies na restauração da paisagem florestal terá uma visão mais ampla ao se valer das

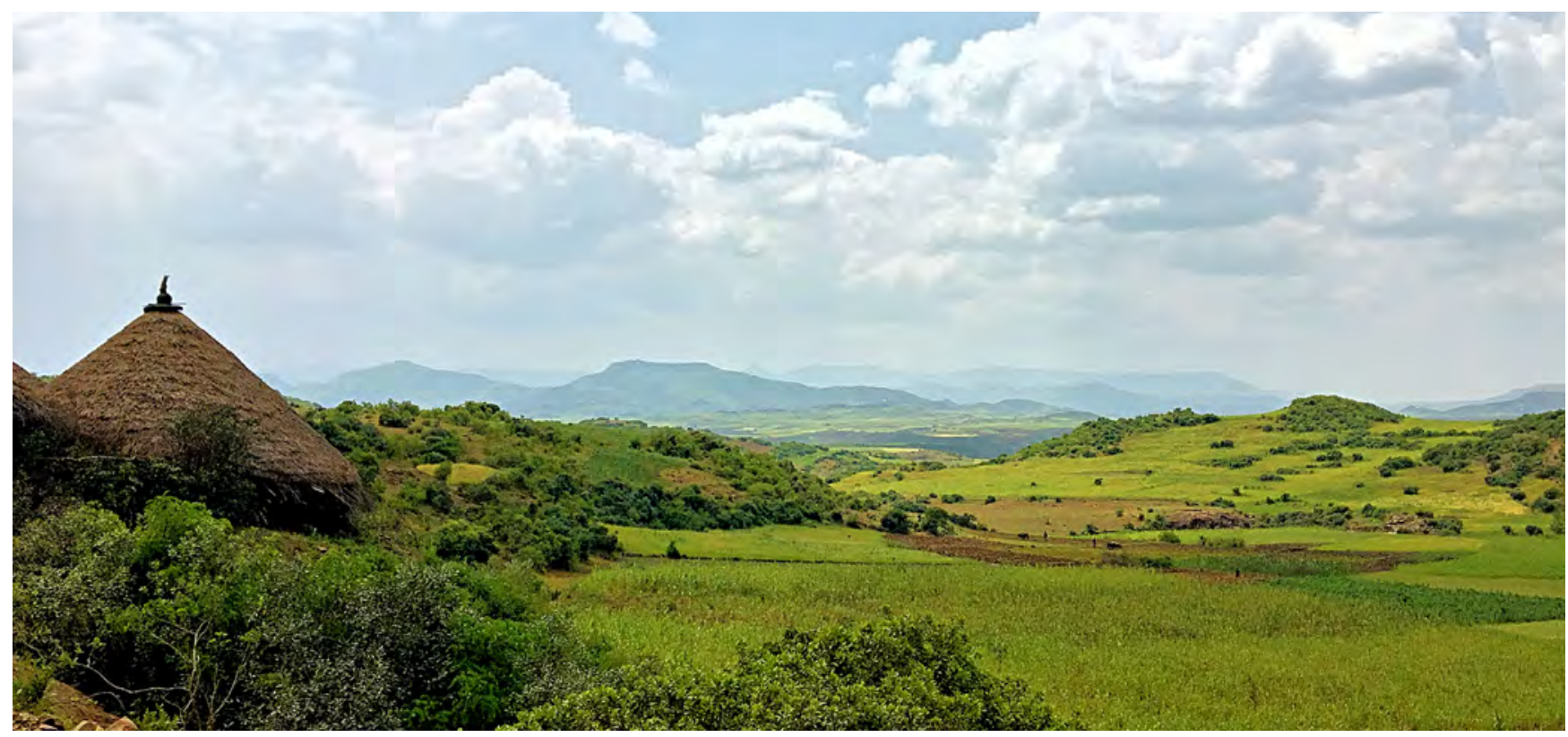

A Etiópia comprometeu-se a restaurar 15 milhões de hectares de terras degradadas ou desmatadas em apoio ao Desafio de Bonn. Grande parte deste compromisso será realizado em paisagens como esta, na região de Ahmara. Foto cedida por Adriana Vidal/UICN 
capacidades das espécies para restaurar as paisagens através de contribuições para um ou vários serviços. Além disso, um enfoque na avaliação de características da paisagem (por exemplo, diversidade geomorfológica e ecótonos de habitat) e outros catalisadores espaciais da biodiversidade e os processos que criam a diversidade, devem ser abordados (Pressey et al., 2007; Anderson e Ferree, 2010). Estes podem incluir ações como melhorar a capacidade de retenção de água, prevenir a perda ou lixiviação do solo, a construção ativa do solo, maior dispersão e recrutamento de sementes e assim por diante, enquanto ao mesmo tempo se fornecem ganhos económicos e de subsistência às pessoas através de produtos como frutas e grãos, forragem, aumento da produção de alimentos, geração de eletricidade e segurança etc. A produtividade ecológica que a FLR trabalha para restaurar pode, assim, ser mensurada em termos sociais e económicos. À medida que as paisagens são restauradas, a crescente diversidade taxonómica e funcional da paisagem levará a paisagens e ecossistemas mais resilientes.

Desde o primeiro momento, o aumento da biodiversidade do solo e da heterogeneidade do substrato é uma importante consideração a ser feita, ainda que muitas vezes subestimada, na restauração da paisagem florestal. Idealmente, a escolha de espécies para intervenções de FLR deve incluir aquelas que são críticas em termos da ciclagem de nutrientes, modificando a paisagem de forma a dar suporte à produtividade ecológica e ao ciclo da água (por exemplo, aumentando a evapotranspiração) - para citar alguns.

Raramente uma espécie gera, de forma independente, serviços ecossistémicos e, portanto, o foco numa espécie na FLR ou na restauração do ecossistema seria uma atitude míope. São as relações biofísicas ou tróficas entre as espécies que geram os serviços ecossistémicos dos quais as pessoas dependem; portanto, as estratégias de restauração paisagística devem empregar um conjunto diversificado de ações de restauração e usar uma abordagem ecossistémica para a escolha de espécies que ajudará a criar as condições ecológicas aprimoradas para a paisagem como um todo.

Ainda que, muitas vezes, não seja mais adequado ou prático restaurar paisagens degradadas e desmatadas em relação a níveis de referência anteriores, os praticantes da restauração podem incluir componentes destes ecossistemas e níveis de referência para orientar a tomada de decisões sobre intervenções apropriadas de restauração da paisagem florestal. Em muitas partes do mundo, a degradação é grave ao ponto de as espécies serem regionalmente extirpadas ou extintas e o ecossistema subjacente ter entrado em colapso ou terse alterado. Nesses casos extremos, e em casos menos graves, a restauração com vista a um novo estado adaptado é uma conclusão necessária. A restauração de ecossistemas no âmbito da paisagem através da restauração da diversidade funcional de espécies, é uma das melhores oportunidades para a restauração da paisagem nessas áreas gravemente degradadas e pode gerar os benefícios multifuncionais desejados pelas pessoas que habitam os ecossistemas de paisagens restauradas.

Como não existe uma definição padrão global e uma classificação de ecossistema, a avaliação quantitativa da diversidade no âmbito do ecossistema, habitat ou comunidade, permanece problemática (World Conservation Monitoring Centre, 1992). No entanto,

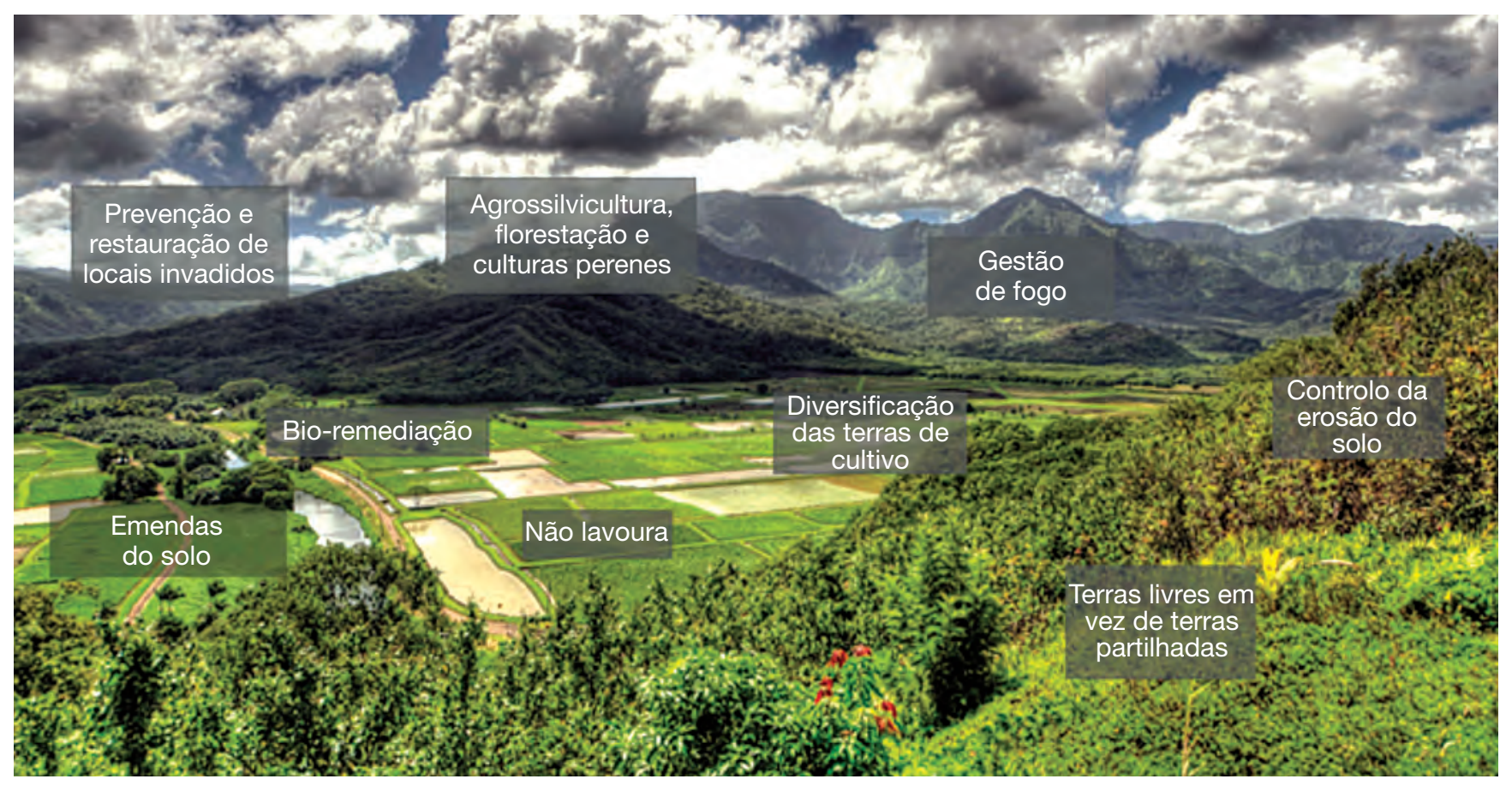

Figura 1. A abordagem da paisagem para a restauração da paisagem florestal a partir do Atlas Global da Biodiversidade do Solo (Orgiazzi et al., 2016) 
a UICN e os seus parceiros estão a desenvolver uma classificação de ecossistemas padrão por meio da Lista Vermelha de Ecossistemas, em andamento (https://iucnrle.org/).

A capacidade das paisagens de resistir a choques e de se recuperarem de distúrbios é a forma como é mensurada a resiliência das paisagens. Todos os ecossistemas são dinâmicos, assim como as espécies que os compõem - ainda que em diferentes escalas de tempo e faixas geográficas. Uma paisagem é frequentemente definida com base nas interações entre os ecossistemas. A forma como comunidades e grupos de espécies dentro de um ecossistema respondem a mudanças ambientais determinará a resiliência desse ecossistema.

Indivíduos no interior de um ecossistema vivem e reproduzem-se, e a persistência das espécies é a primeira condição para se manter a resiliência ecológica.
Como a degradação reduz o número de espécies numa paisagem por extirpação física através da limpeza da terra, o desmatamento, o excesso de colheita ou qualquer outra atividade que reduza ou elimine espécies da paisagem - a resiliência do ecossistema e, por extensão, a resiliência da paisagem, sofrerão. Geralmente, quanto menos espécies compõem um ecossistema, menos resiliente ele é. A restauração da paisagem florestal, por definição, ocorre em áreas onde as espécies nativas e as suas funções foram perdidas; e a recuperação da função ecológica de uma área degradada baseia-se na expansão, estabelecimento ou reintrodução de espécies que preenchem lacunas funcionais para paisagens degradadas. A forma como essas lacunas funcionais são preenchidas depende de muitos fatores, mas está claro que uma abordagem que se vale de uma diversidade de espécies, construirá ecossistemas e paisagens mais resilientes do que uma abordagem que não o faz. A consideração de espécies

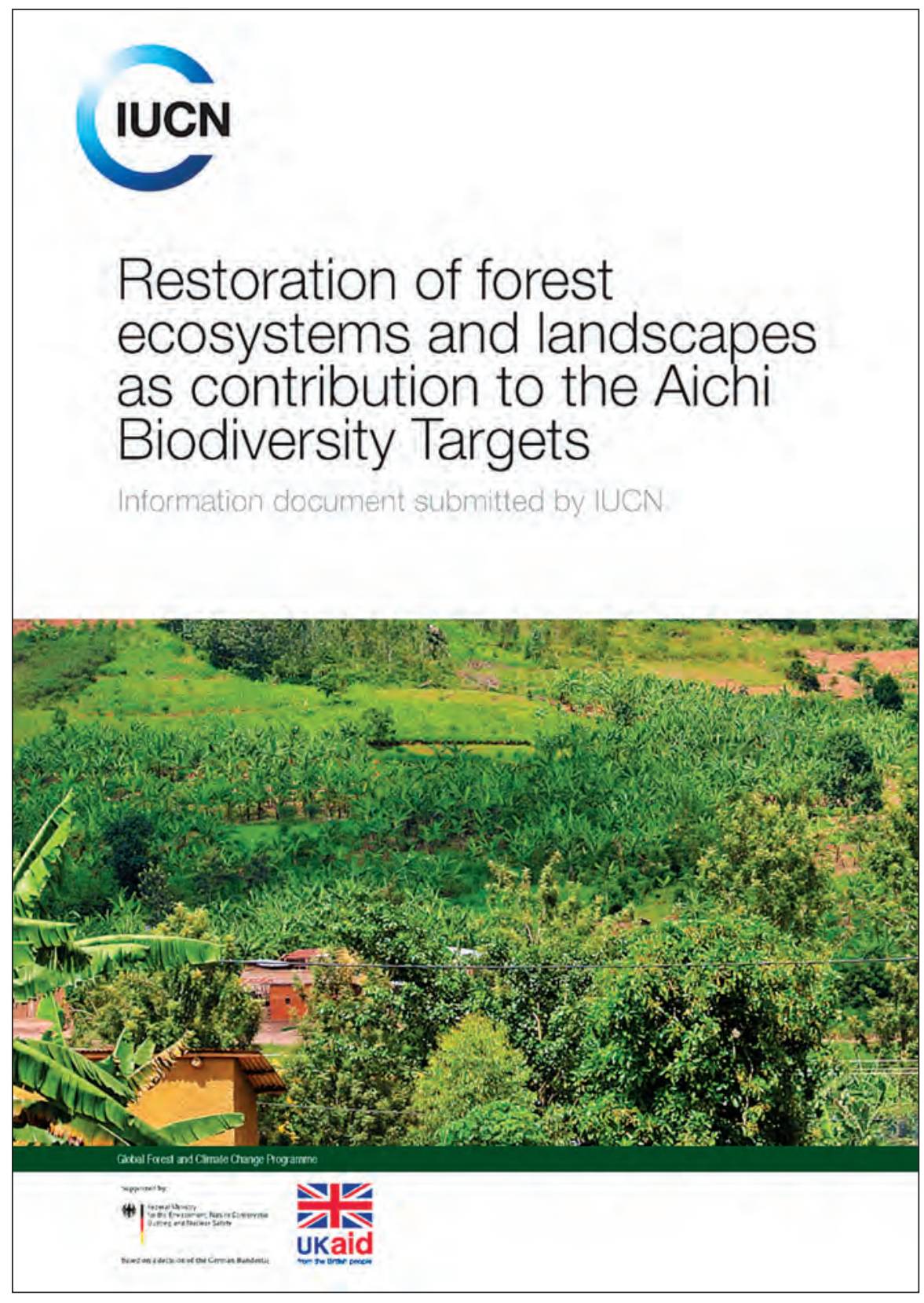

A Figura 2 foi incluída como documento oficial de informação da $13^{\mathrm{a}}$ Conferência das Partes da Convenção sobre Diversidade Biológica, em 2016. Esta publicação fornece informações sobre como a implementação da restauração da paisagem florestal (FLR) a nível jurisdicional e nacional, pode oferecer aos países uma forma de recuperar florestas degradadas e trazer de volta a função-chave do ecossistema, de forma a aumentar os níveis de biodiversidade numa paisagem para ajudar a alcançar várias Metas de Biodiversidade de Aichi. 
ecologicamente apropriadas é um dos passos mais importantes que podem ser dados na restauração da paisagem florestal.

Um ponto de partida óbvio para se considerar as espécies a serem usadas na restauração é o solo e as espécies de plantas. Grande parte da degradação que assola as paisagens começa com o declínio da qualidade do solo ou a erosão do solo superior e a lixiviação dos seus nutrientes. A restauração das condições do solo que dão suporte ao crescimento vegetal é fundamental, especialmente o restabelecimento de espécies de plantas como parceiros que se sucedem, geralmente em combinação com intervenções de restauração da paisagem, como sistemas agroflorestais, áreas florestais e sistemas agrícolas sustentáveis.

No mínimo, a restauração da paisagem florestal deve incluir algum componente de uma abordagem ecossistémica integrada para a restauração. Isto exigirá que os praticantes da restauração tenham um conhecimento prático dos tipos de ecossistemas na sua geografia, bem como das espécies notáveis ou fundamentais. Uma abordagem de espécies diversificadas para melhorar a biodiversidade nativa e aumentar a conectividade entre paisagens fragmentadas, ecossistemas e habitats deve ser o resultado de qualquer avaliação de restauração. De forma alternativa, onde a degradação extirpou muitas espécies, essa abordagem pode ajudar a construir ecossistemas com espécies nativas com base em características funcionais que sejam desejáveis, como fixação de nitrogénio, predadores ou dissuasão de animais que se alimentam de plantas, ou habitat crítico para outras espécies com as quais deve haver preocupação ou zelo.

Os benefícios socioeconómicos ecológicos e associados resultantes da integração da restauração e conservação da biodiversidade no planeamento da FLR, juntamente com os conceitos de diversidade genética, de espécies e de ecossistemas, podem ser utilizados para medir o progresso que os países podem fazer para cumprir compromissos internacionais como a Convenção sobre Diversidade Biológica (CDB) e os Objetivos de Desenvolvimento Sustentável da ONU (particularmente os Objetivos 15 [Vida na Terra] e 13 [Ação Climática]). O Artigo 6 da CDB merece menção especial, pois solicita que os países preparem Estratégias e Planos de Ação Nacionais para a Biodiversidade (EPANB) que são especialmente importantes para a implementação nacional da CDB. Através do planeamento e da ação da FLR em larga escala, as jurisdições podem dar apoio a metas específicas para a conservação da biodiversidade nacional e internacional, enquanto restauram a produtividade ecológica das paisagens das quais as pessoas necessitam. A segunda parte destas diretrizes descreve como os praticantes podem operacionalizar um interesse ou realizar um contrato com a inclusão explícita da biodiversidade no planeamento da FLR. Também são sugeridas algumas fontes e metodologias de informação importantes para garantir que o planeamento da paisagem para a FLR também inclua o conhecimento da biodiversidade que pode ajudar a conduzir o planeamento de restauração para o sucesso de restauração a longo prazo.

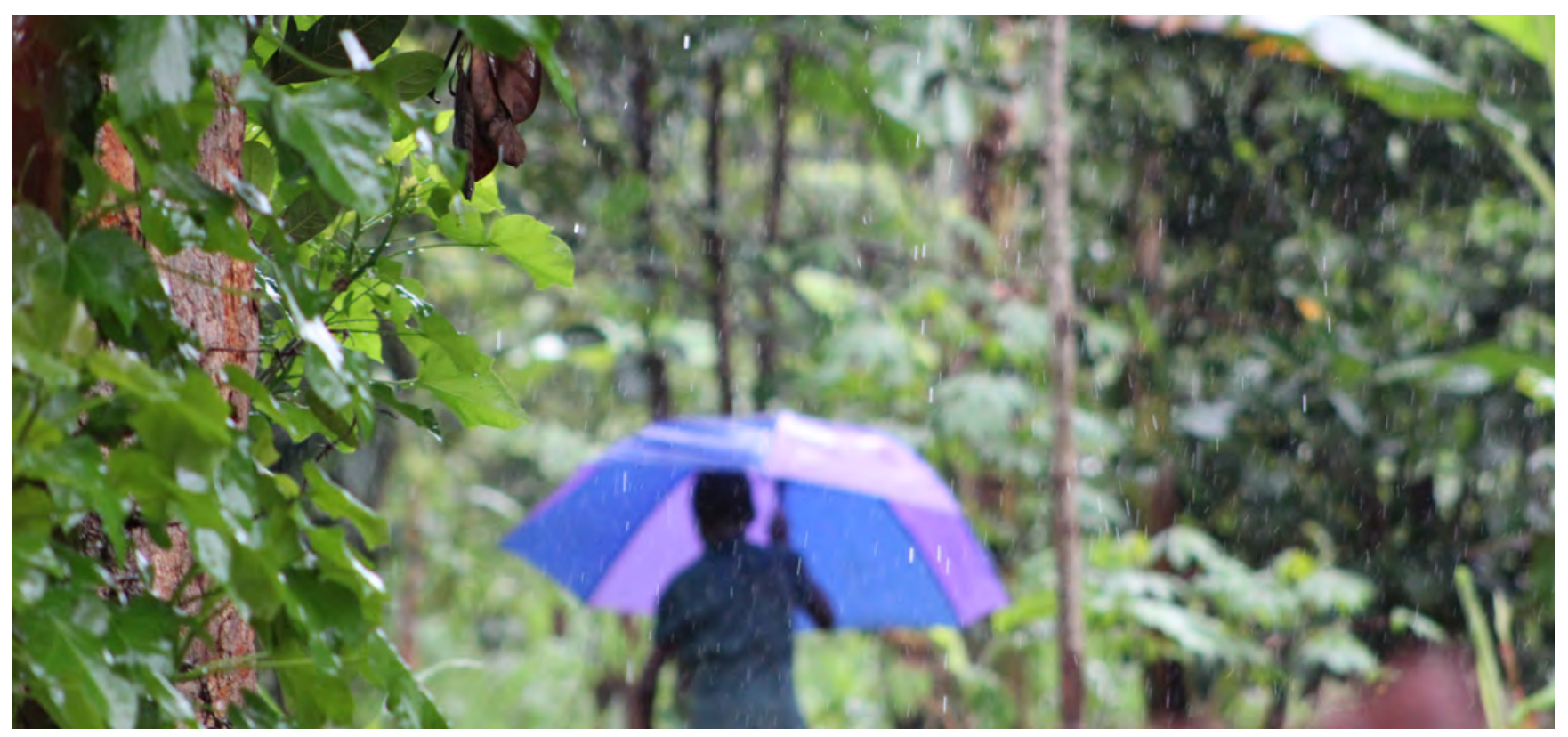

Ainda que o Uganda tenha concluído a sua avaliação nacional das oportunidades de restauração da paisagem florestal em 2016, a implementação e avaliações adicionais no nível subnacional estão em andamento. Isso inclui o foco no manejo sustentável da terra em distritos agrícolas, com associações agrícolas e o engajamento de grupos de jovens em paisagens de trabalho como aqui no distrito de Mukono. Foto cedida por Craig Beatty/UICN. 


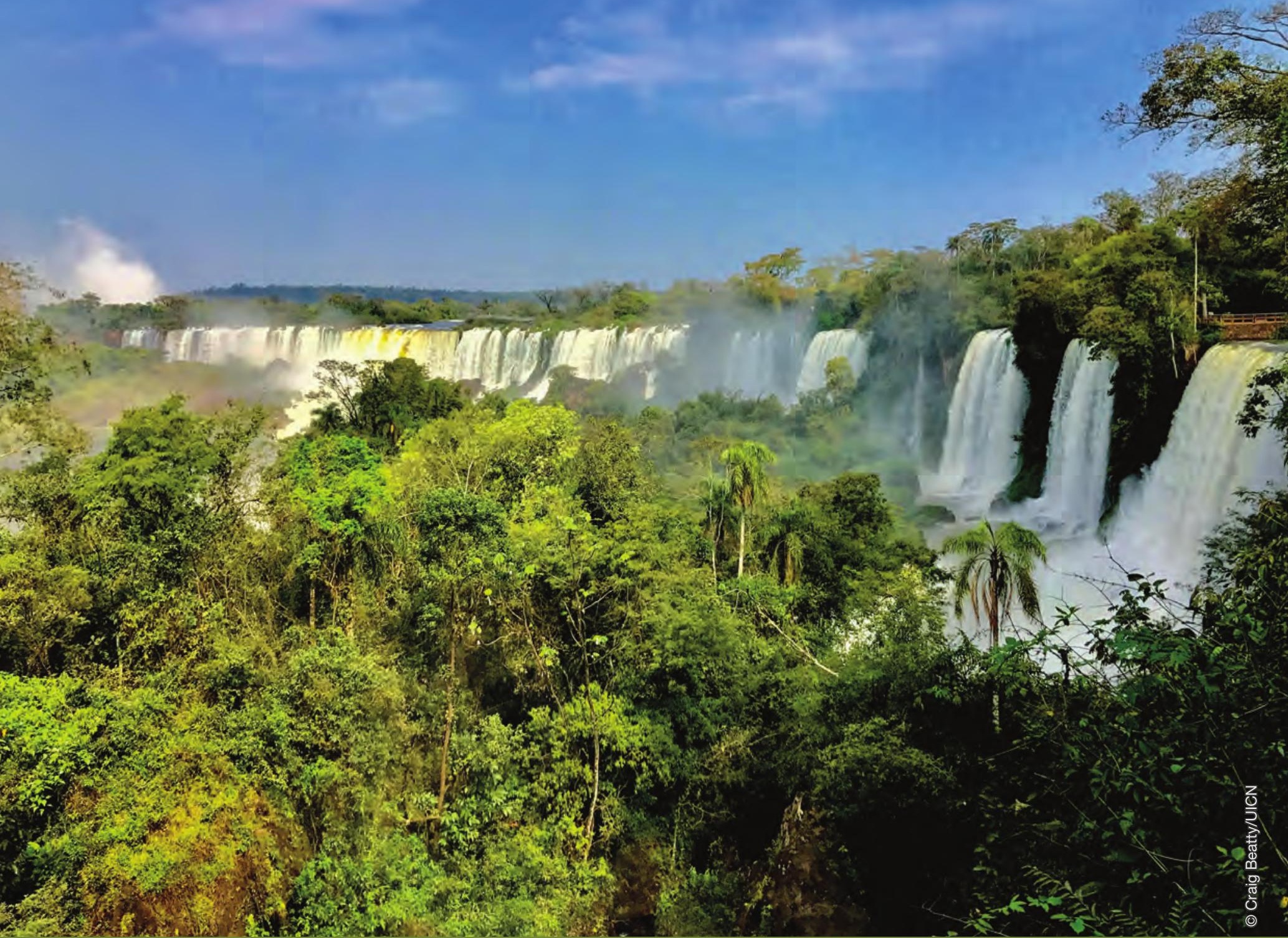

\section{Parte dois}

\section{Biodiversidade no planeamento de avaliações de restauração da paisagem florestal}


Nalgumas metodologias existentes (ver, por exemplo, UICN e WRI, 2014), há várias razões claras delineadas sobre o valor das atividades de FLR bem planeadas para a manutenção ou restauração da biodiversidade e os seus benefícios. Aqui será fornecida orientação adicional, para o praticante de restauração, sobre como abordar de forma mais abrangente e prática a biodiversidade nas avaliações de restauração da paisagem florestal.

$\mathrm{Na}$ avaliação das oportunidades de restauração, as partes interessadas primeiro identificarão as suas metas de restauração da paisagem florestal, e esse processo levará a diferentes tipos de ações de restauração que, quando implementadas, deverão atenuar os fatores subjacentes à degradação da paisagem. Cada uma dessas soluções envolverá ações (ou seja, "intervenções de restauração") que precipitam transições físicas de paisagens degradadas para restauradas e mais produtivas.

Subjacente a cada uma dessas transições há processos biológicos que dão apoio à expansão das populações ou à diversidade de uma ou muitas espécies. De facto, sem ganhos na diversidade vegetal, animal, fúngica e microbiana, há pouca esperança de sucesso de restauração a longo prazo para uma produtividade aumentada e sustentável. No seu nível mais fundamental, a restauração da paisagem florestal destina-se a construir ou apoiar ecologias resilientes que são centradas nas relações interconectadas entre espécies e grupos tróficos funcionais e como estes são inerentemente benéficos

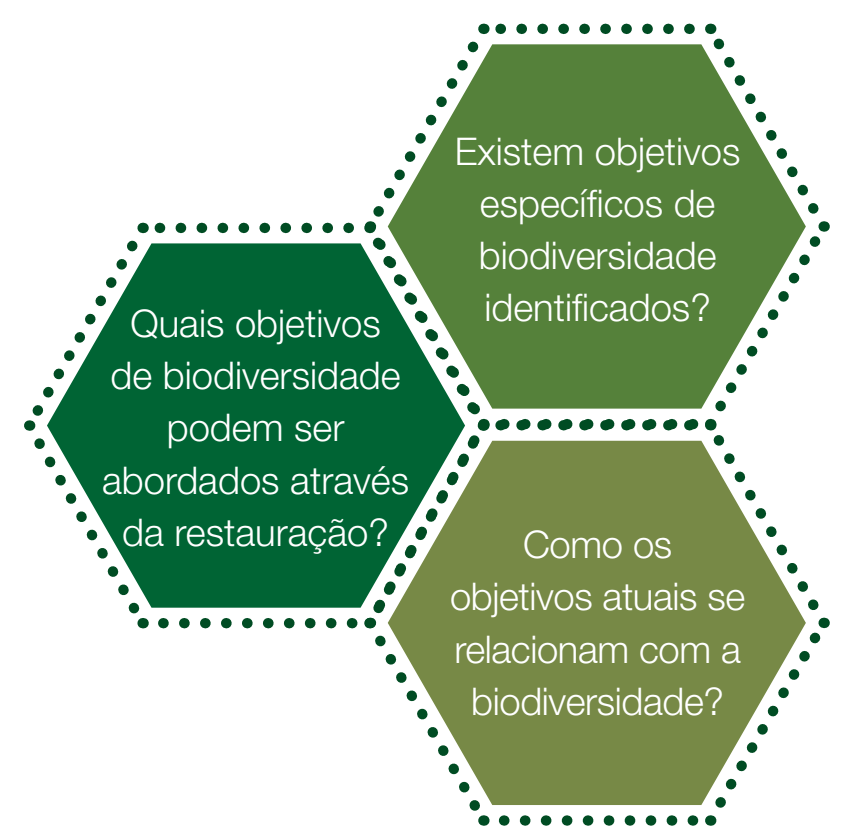

para a subsistência e bem-estar humanos (por exemplo, aumentando a biodiversidade nos solos para aumentar a fertilidade do solo) (Reitbergen-McCracken et al., 2007; Lamb, 2014).

Ao considerar os objetivos da FLR e os benefícios associados à biodiversidade, é importante reconhecer que o problema ou os desafios a serem tratados em termos de biodiversidade e espécies devem estar alinhados, ou apoiar, os objetivos das políticas nacionais

Tabela 1. Alinhamentos entre os objetivos típicos da FLR e a biodiversidade

\section{Exemplos de objetivos da FLR}

Segurança alimentar

Segurança da água

Produção sustentável

\section{Alinhamentos de biodiversidade}

A biodiversidade sustenta a agricultura (incluindo a agrossilvicultura), especialmente através da resiliência à mudança ambiental por variedades e espécies adaptadas localmente, e através de uma provisão de bens mais diversificada. Atualmente, é amplamente reconhecido que os ecossistemas saudáveis e especialmente as florestas, representam um importante repositório de alimentos e recursos que desempenham um papel fundamental na contribuição para a segurança alimentar (Sunderland, 2011).

As florestas são amplamente reconhecidas como uma boa proteção natural a montante para o abastecimento de água e existem vários exemplos de degradação dos cursos de água a jusante (incluindo a qualidade da água) em locais em que ocorreu o desflorestamento de terras altas. As paisagens biodiversas são muitas vezes consideradas mais eficazes na prestação de serviços ecossistémicos e são mais eficientes na proteção das fontes de água (Secretaria da Convenção sobre Diversidade Biológica, 2013; Herrera et al., 2018). Estes ecossistemas e paisagens florestais também são importantes para promover a recarga das águas subterrâneas e apoiar a conexão hidrológica (Pringle, 2001; Hatton e Nulsen, 1999).

A conservação e a restauração da biodiversidade entre paisagens é globalmente reconhecida como um contribuinte direto para o desenvolvimento de sistemas de produção sustentáveis, especialmente na silvicultura, agricultura, pesca, produtos farmacêuticos, celulose e papel, cosméticos, horticultura, turismo, construção e biotecnologia (Meta 12 dos ODS). 
Exemplos de

objetivos da FLR

Alinhamentos de biodiversidade

Sequestro de carbono

A restauração futura de paisagens degradadas (especialmente nos trópicos) e o potencial de sequestro de carbono associado, é agora uma solução baseada na natureza bem estabelecida para a mitigação das mudanças climáticas em curso (Griscom et al., 2017). Embora pouco se saiba sobre os impactos da perda de biodiversidade na mitigação de florestas e habitats associados, muitas vezes se assume que as áreas de biodiversidade são mais eficientes no armazenamento de carbono (Nauman et al., 2014; Griscom et al., 2017) e uma pesquisa de Vayreda e colegas (2012) demonstra o impacto positivo que o manejo da paisagem florestal como uma intervenção da FLR pode ter sobre o sequestro de carbono nas florestas espanholas.

Resiliência Os sistemas geneticamente biodiversos têm maior resiliência às mudanças ambientais (por exemplo, resiliência às mudanças climáticas) do que as paisagens degradadas. Embora isso possa não ser aparente no curto prazo, a variação desde o interior das espécies até às paisagens pode ser crucialmente importante para a resiliência de longo prazo das funções do ecossistema e dos serviços aos quais elas dão suporte (Oliver et al., 2015a; Oliver et al., 2015b).

Redução da pobreza Os recursos da biodiversidade e os ecossistemas são regularmente subvalorizados como bens públicos. Isto é especialmente importante quando se considera a dependência desproporcional que as pessoas pobres têm da biodiversidade para as suas necessidades de subsistência, tanto em termos de renda e segurança contra o risco, como às vezes como um caminho para sair da pobreza (Secretaria da Convenção sobre Diversidade Biológica, 2010). A ligação entre a biodiversidade e as perspetivas das pessoas pobres indica que a conservação da biodiversidade (incluindo os esforços de restauração) deve ser uma prioridade nos esforços internacionais para abordar a redução da pobreza (Secretaria da Convenção sobre Diversidade Biológica, 2010).

Meios de subsistência A importância das florestas e de outros ecossistemas saudáveis enquanto oportunidades para a extração sustentável (fortemente ligada aos componentes da biodiversidade de tais ecossistemas) é clara. Deve-se notar, no entanto, que os suprimentos dos ecossistemas podem ser inflexíveis, e baixos retornos comumente limitam o seu papel de redes de segurança e caminhos para se sair da pobreza (Wunder, 2014). O acesso das pessoas a esses recursos, juntamente com as fontes diversificadas de produtos florestais não madeireiros, é uma consideração importante a fazer-se ao avaliar o valor dos ecossistemas para as comunidades e, potencialmente, a conservação sustentada desses habitats.

e internacionais existentes ou em desenvolvimento associadas à restauração da paisagem florestal. Desafios para manter ou restaurar a biodiversidade em escala nacional são frequentemente registados em documentos existentes, tais como Estratégias e Planos de Ação Nacionais para a Biodiversidade (EPANB), o principal instrumento para os países implementarem os seus compromissos assumidos na Convenção sobre Diversidade Biológica (CDB). Os objetivos contidos nas EPANB e noutros documentos centrados na biodiversidade geralmente concentram-se na restauração de populações de espécies individuais ou na manutenção de áreas de diversidade de espécies reconhecidas e prioritárias. Embora os documentos da EPANB e similares sejam especialmente úteis para os objetivos nacionais, se as atividades da FLR forem planeadas ao nível subnacional, uma consideração adicional de desafios mais localizados pode ser necessária (veja a secção seguinte sobre Estratégias Nacionais da Biodiversidade e Planos de Ação).
Em alguns casos, talvez mais regularmente a nível subnacional, os objetivos de restaurar ou manter a biodiversidade para inclusão no processo de FLR podem não ter sido explicitamente considerados. Nestes casos, os praticantes da FLR precisarão identificar e contactar os especialistas locais, nacionais e internacionais apropriados para fornecer orientação (veja a secção seguinte sobre Engajamento de profissionais da biodiversidade).

Durante o processo de considerar a biodiversidade dentro do cronograma de avaliação de restauração, é sempre importante que as ligações positivas entre um ambiente restaurado, saudável e biodiverso e outros setores de interesse (especialmente aqueles relacionados ao desenvolvimento humano) sejam bem articulados, para assegurar os decisores quanto ao retorno social positivo do investimento proporcionado pela restauração da biodiversidade, como parte do processo geral da FLR (ver Tabela 1 para exemplos de 
relações entre a biodiversidade e muitos dos objetivos típicos da FLR).

As principais partes interessadas a serem consideradas e envolvidas durante a fase de planeamento do projeto, e as atividades de recolha de dados que são especialmente importantes para a aquisição de informações relevantes sobre a biodiversidade, incluirão os responsáveis pela tomada de decisões governamentais (incluindo funcionários ministeriais ou de secretarias); representantes de ONGs apropriadas (por exemplo, sociedades de história natural ou organizações nacionais/locais de conservação); jardins botânicos; instituições académicas; comunidades locais e grupos indígenas; pessoal técnico apropriado do governo, da sociedade civil ou do setor privado (frequentemente das secretarias de silvicultura e vida selvagem); utilizadores comerciais de produtos da vida selvagem ou recursos naturais dentro da área de interesse; e pessoal de apoio técnico, talvez especialmente aqueles com competências de modelagem ambiental e socioeconómica.

\section{Envolvimento de profissionais da biodiversidade}

Além de uma instituição dedicada responsável por coordenar o processo global de avaliação e planeamento de restauração (conforme descrito em UICN e WRI, 2014), certas equipas técnicas são fundamentais paragarantirque os profissionais adotem uma abordagem equilibrada para a FLR. A principal necessidade será o acesso a um ecologista com conhecimento substancial dos ecossistemas nativos e da fauna e flora a eles associados, que normalmente estaria presente na área sob consideração para atividades de restauração. Esta orientação contribuirá para se compreenderem os vários custos e benefícios ecológicos da restauração planeada e a linha do tempo ou cronograma para a realização dos objetivos do projeto. Igualmente importante é envolver a participação de um naturalista ou alguém que esteja familiarizado com o conhecimento tradicional e os valores culturais da biodiversidade na(s) área(s) de interesse. A cooperação de um ecologista clássico e de uma parte interessada e familiarizada com os aspectos tradicionais e culturais da biodiversidade, ajudará a garantir que cada uma dessas perspectivas seja incluída e validada durante 0 processo de avaliação.

Estas principais funções consultivas ajudarão a garantir que o investimento no trabalho de restauração esteja efetivamente a abordar os desafios e objetivos da paisagem. $O$ ecologista e 0 naturalista também serão capazes de aconselhar sobre a melhor forma de acompanhar o progresso da restauração (incluindo relatórios sobre os indicadores de biodiversidade estabelecidos; veja Monitorização do impacto da FLR na biodiversidade e nas comunidades). Em alguns casos, pode ser difícil identificar um ecologista com as competências necessárias para fornecer conselhos sobre a fauna e flora nativas de uma paisagem. Nestes casos, um botânico ou biólogo da vida silvestre podem ser contratados para o lugar do ecologista, porém este biólogo precisará ter um bom conhecimento dos princípios ecológicos e acesso a uma rede de apoio de zoólogos e botânicos especializados (como a Comissão de Sobrevivência das Espécies da UICN, https://www.iucn.org/ssc-groups).

Outra consideração importante no envolvimento com parceiros sobre biodiversidade e FLR é o alinhamento de perspectivas e expectativas. Embora haja ganhos potenciais significativos a partir da inclusão explícita de informações sobre biodiversidade em avaliações de restauração da paisagem florestal, a inclusão de partes interessadas focadas exclusivamente em biodiversidade ou silvicultura, às vezes pode criar tensões, mas a sua inclusão é necessária. Gerir expectativas em relação aos resultados da FLR pode ser um processo delicado, mas em última instância o objetivo da restauração da paisagem florestal é restaurar a funcionalidade do ecossistema para o benefício tanto das pessoas quanto do planeta. Se a conservação e restauração da biodiversidade não é o principal ponto de entrada para uma avaliação de

Alguns exemplos de possíveis reflexões sobre biodiversidade dentro das avaliações da FLR:

1. Incluir e comunicar-se com pessoas que se preocupam e apoiam a biodiversidade, incluindo pontos focais nacionais para a Convenção sobre Diversidade Biológica, instituições académicas e sociedades naturalistas.

2. Utilizar conhecimentos e informações relevantes sobre espécies e ecologia na recolha de dados e análise de oportunidades de FLR.

3. Fornecer resultados e recomendações adequados que possam ser comunicados entre os setores (de ONGs de conservação a Ministérios da Agricultura/Finanças, etc.) 
oportunidades de restauração da paisagem florestal, podemos assumir com segurança que alguns ganhos de biodiversidade serão concretizados, e é importante quantificá-los. Se o ponto de entrada para uma avaliação de oportunidades de FLR é conseguir uma conservação mais substancial da biodiversidade e/ou a restauração de áreas de alto valor de biodiversidade, então os seus ganhos são o objetivo explícito da restauração da paisagem florestal. Em ambos os casos, haverá ganhos de biodiversidade que valem a pena incluir no processo de avaliação, nos resultados e na monitorização da FLR. As partes primordialmente interessadas na conservação da biodiversidade devem reconhecer o potencial de tais ganhos, mesmo queapaisagemnãosejanecessariamente restaurada ao seu estado de referência, ecossistema ou vegetação originais. As partes interessadas nos múltiplos objetivos que a FLR pode trazer devem sempre considerar os benefícios da conservação e restauração para a biodiversidade.

Uma ação de clara importância ao longo da fase de planeamento e preparação é garantir que as partes interessadas no processo da FLR estejam cientes de quaisquer impactos potenciais (positivos ou negativos) resultantes da consideração crescente da biodiversidade dentro da área de restauração delineada e nas áreas adjacentes ou associadas. O feedback durante a fase de planeamento e preparação de partes interessadas da sociedade civil, incluindo representantes de governos, agências não governamentais e comunidades locais/indígenas, informará enormemente o projeto, especialmente sobre quaisquer assuntos ou iniciativas controversos.

\section{Monitorização do impacto da FLR na biodiversidade e nas comunidades}

Monitorar o progresso em direção ao cumprimento dos objetivos da FLR será um processo que normalmente se adapta à disponibilidade de recursos ou oportunidades locais, e a mesma ocorrerá assim que as ações de restauração estiverem em andamento. A monitoria ocorre durante e após o processo físico de restauração e também é uma consideração importante a ser feita no período de recolha e avaliação de dados. No entanto, é imperativo que as estruturas e indicadores de monitoria sejam discutidos e acordados pelas partes interessadas durante o processo de avaliação. Isso configurará as condições que possibilitarão a monitoria, estejam elas concluídas ou não. Muitos dos dados de entrada para a avaliação também servirão como indicadores potenciais do progresso da FLR e, mais importante, as bases de referência serão medidas e definidas durante a fase de avaliação.

Embora alguns indicadores de biodiversidade sejam comuns (por exemplo, cobertura de habitat, diversidade de espécies, área sob proteção), os métodos precisos utilizados variam entre habitats e ecossistemas. Por exemplo, a monitoria de populações de espécies ou comunidades pode exigir abordagens diferentes em florestas de savana, em comparação com as florestas tropicais de planície ou alto deserto, e também dependerá do engajamento e da continuidade das partes interessadas. No entanto, existe uma variedade de ferramentas padronizadas e protocolos de monitoria que podem ser usados ou adaptados conforme necessário para a maioria dos principais grupos de plantas e animais. Os avanços tecnológicos tornaram as ferramentas mais baratas e acessíveis, como deteção remota por drones ou por satélite, sensores in situ, como armadilhas fotográficas ou dispositivos de gravação acústica, e monitoria de DNA ambiental, todos os quais terão um papel a desempenhar em algumas paisagens em restauração. Sempre que possível, os dados recolhidos devem alimentar não apenas esquemas de relatórios em escala de paisagem e nacional, mas também processos de pesquisa, monitoria e avaliação que dão apoio a bancos de dados globais como a Lista Vermelha de Espécies Ameaçadas da UICN, Planeta Protegido e o Índice do Planeta Vivo. Esta ação em especial é importante, pois os dados desses bancos de dados são usados para medir o progresso em direção à realização de metas ambientais globais (como as Metas de Aichi e os Objetivos de Desenvolvimento Sustentável). A UICN recebe de bom grado mais contribuições para a Lista Vermelha de Espécies Ameaçadas sobre distribuições de espécies, história natural, ameaças e estatuto de conservação. Para enviar novas informações para a UICN, use o seguinte endereço de e-mail: redlist@iucn.org. Além disso, o Grupo de Especialistas em Monitoria da Comissão de Sobrevivência de Espécies da UICN, é um recurso fundamental ao projetar ou implementar estratégias ou para a implementação da FLR.

A UICN também criou indicadores de biodiversidade para a Lista Vermelha de Ecossistemas que continuarão a se desenvolver nos próximos anos. O envolvimento com os profissionais da Lista Vermelha de Ecossistemas e da Comissão da UICN sobre Manejo de Ecossistemas garantirá que a biodiversidade e a monitoria de ecossistemas nas avaliações de FLR, também apoiem esses critérios internacionais sobre o estatuto de conservação dos ecossistemas.

O envolvimento com comunidades locais e outras partes interessadas no cenário da FLR para monitorar o progresso da restauração é uma maneira prática de facilitar a apropriação local do processo da FLR e estabelecer um meio eficiente e regular de rastrear mudanças na biodiversidade. Esforços devem ser feitos para identificar um importante ecologista de restauração (nacional ou internacional) que possa trabalhar com especialistas locais nos ecossistemas a serem restaurados. Este especialista pode fornecer 
orientação para as partes interessadas locais (por exemplo, estudantes universitários locais ou grupos de entusiastas da vida silvestre) no processo de monitoria de como determinar se os esforços de restauração estão a funcionar ou se é necessária atenção adicional para alcançar os objetivos da paisagem. Exemplos de oportunidades de rastreio podem incluir registar visitas de espécies-alvo ameaçadas em áreas sob restauração; contagens do número de indivíduos de uma espécie arbórea nativa que se regenera a partir do banco de sementes existente; ou melhorias para um serviço de ecossistema em terras agrícolas vizinhas (por exemplo, aumentos de fixação de frutos ligados à abundância da população de polinizadores nativos). Estas oportunidades de ciência cidadã podem melhorar a recolha de dados, aumentar a sustentabilidade dos programas de monitoria e melhorar o engajamento entre os proponentes da FLR e as comunidades locais para ações de restauração. Sem a participação local, será difícil monitorar a variedade de formas pelas quais a FLR afetou a prestação de serviços ecossistémicos e os benefícios ou custos sociais que resultaram das atividades de restauração.

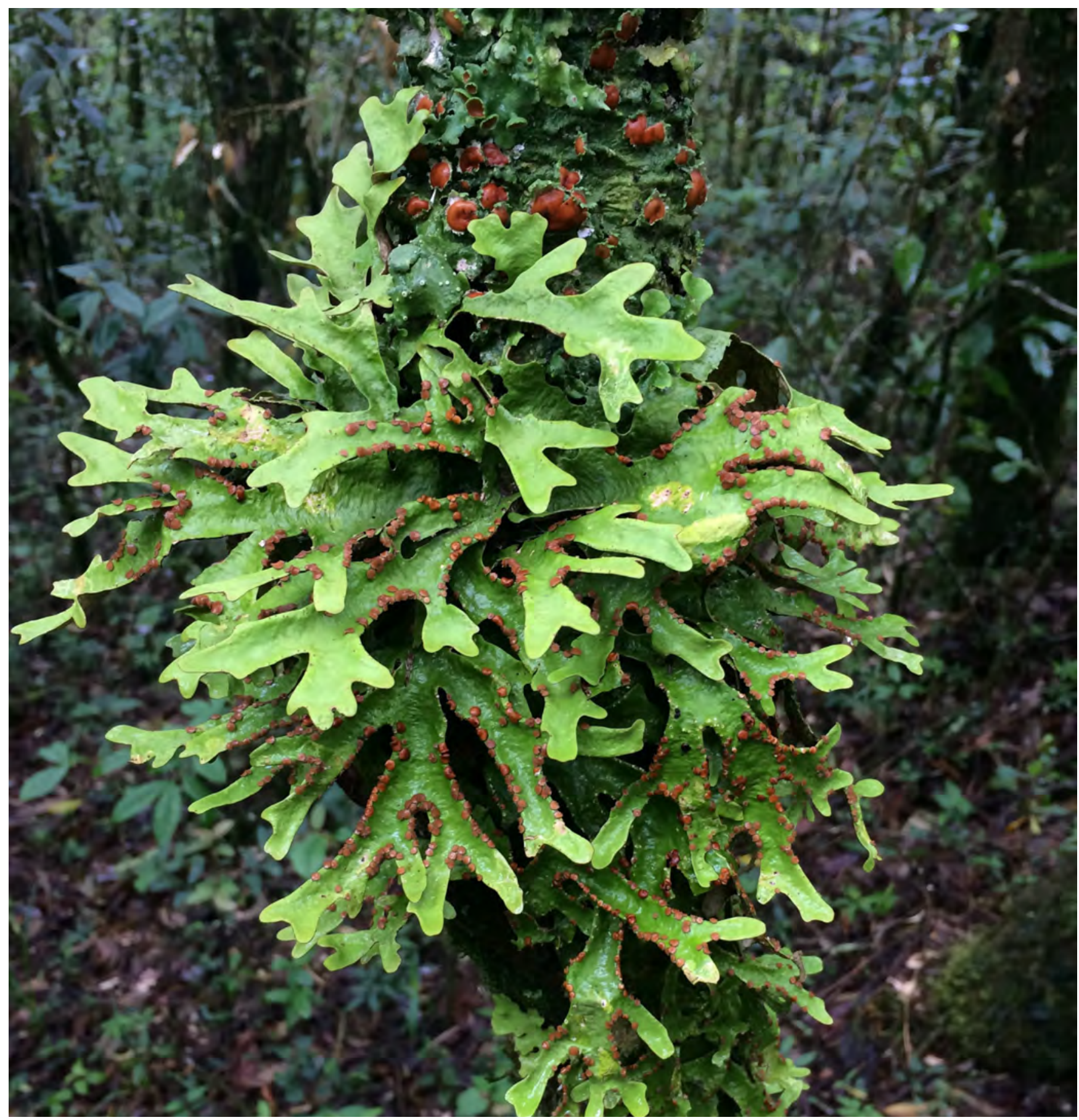

Líquen Sticta angstroemii (Lobariaceae, Ascomycota) fotografado em uma floresta de nuvem fragmentada em Campos do Jordão, São Paulo, Brasil. Os liquens de Lobariaceae podem ser usados como bioindicadores para fins de conservação, pois são usados para detetar fragmentos florestais remanescentes, neste caso a Mata Atlântica. Foto cedida por Manuela Dal Forno. 


\section{Informação sobre biodiversidade para o processo de avaliação}

Após o envolvimento das principais partes interessadas do setor da biodiversidade e o estabelecimento de um processo de avaliação de restauração da paisagem florestal, como a Metodologia de Avaliação de Oportunidades de Restauração (ROAM, por sua sigla em inglês), a atenção voltar-se-á para a colheita e análise de dados e informações sobre a FLR. Esta tarefa geralmente será dividida entre grupos de trabalho por tópicos como o mapeamento de partes interessadas, a análise de dados espaciais, o desenho de serviços ecossistémicos, a análise de género, análise de custo-benefício, identificação de empresas, análise de políticas e avaliações de prontidão institucional. Enquanto a maioria dos dados de biodiversidade tende a ser geográfica e taxonómica, a informação sobre biodiversidade deve ser um componente bem-vindo de qualquer grupo de trabalho e normalmente já está incluída de uma forma ou de outra.

\section{Fontes de informação sobre biodiversidade}

Uma vez que os amplos resultados e escopo da FLR tenham sido considerados e acordados, a atenção voltar-se-á para os recursos e dados existentes disponíveis que podem ajudar a informar a avaliação. Normalmente, os resultados e o escopo da FLR são acordados durante a fase inicial de interesse nacional ou subnacional na FLR, como uma solução baseada na natureza para quaisquer desafios sociais e ecológicos. Geralmente, eles são codificados num documento de planeamento de restauração e/ou escopo produzido de forma colaborativa pelas pessoas com os direitos de administrar a terra na área de avaliação identificada. Esse processo deve assegurar que o melhor conhecimento disponível sobre a biodiversidade possa ser integrado a toda a avaliação, usando uma combinação das melhores ciências e informações sobre biodiversidade e o conhecimento mais relevante sobre biodiversidade regional, nacional e local.

\section{Dados nacionais existentes sobre biodiversidade e contatos}

A maioria dos países tem um histórico valioso de recolha e manutenção de informações sobre o seu ambiente natural. Além de informações mais gerais sobre a fauna e a flora do país, também haverá conjuntos de dados associados a mudanças históricas no uso da terra (incluindo a conversão de terras florestais) e práticas de uso da terra realizadas no país. Além disso, pode haver dados disponíveis sobre o uso comercial de espécies, que podem ser usados para orientar o processo de restauração de plantas e animais (incluindo variedades agrícolas e e de parentesco silvestre) agora extraídos ou raros no interior da área de avaliação.

O primeiro passo na colheita de recursos de dados para dar apoio à inclusão substancial de informações sobre biodiversidade no processo de avaliação da FLR, deve ser que a estrutura de gestão da avaliação da FLR (por exemplo, comité técnico da FLR, comité executivo da FLR, organização institucional líder etc.), trabalhe com o profissional de biodiversidade para identificar especialistas locais ou nacionais em silvicultura que estejam dispostos a ajudarna avaliação e planeamento da restauração. Isso incluirá o desenvolvimento de uma lista inicial de contatos dos departamentos governamentais, organizações da sociedade civil, instituições académicas e comunidades locais que provavelmente terão os conhecimentos apropriados. Ao entrar em contato com esses atores-chave, é útil perguntar sobre contatos adicionais de especialistas para garantir que nenhum deles tenha sido negligenciado na pesquisa inicial. Estabelecer uma rede desde o início será muito importante para o desenvolvimento da apropriação local a nacional do processo global de restauração.

Alguns dos principais conjuntos de dados nacionais sobre biodiversidade

Lista Vermelha Nacional de Dados ou Livros de informação - muitos países publicaram listas vermelhas ou livros nacionais sobre dados que identificam e documentam espécies que são prioridades nacionais para conservação. O conteúdo destas publicações varia substancialmente entre os países, algumas são publicações gerais, enquanto outras são extremamente detalhadas nas informações apresentadas. Muitas concentram-se apenas em vertebrados (geralmente grandes mamíferos), mas informações sobre vários grupos taxonómicos, incluindo invertebrados e plantas (como espécies arbóreas ameaçadas) estão a tornar-se mais comuns. A equipa do projeto deve analisar esses documentos para verificar se as espécies listadas podem ser integradas no processo de avaliação e planeamento da restauração e qual valor a sua inclusão traria. Se não estiverem disponíveis publicamente, esses dados podem ser adquiridos entrando em contato com o ponto focal nacional da Convenção sobre Diversidade Biológica ou revendo a Estratégia e Plano de Ação Nacionais para a Biodiversidade (EPANB). 


\section{Estratégias e Planos de Ação Nacionais para a Biodiversidade}

EPANB foram criadas para 189 países membros da Convenção sobre Diversidade Biológica. Isto significa que quase todos os países concluíram uma avaliação recente da sua biodiversidade nacional e formularam uma estratégia e um plano de ação para a conservação da biodiversidade. Não é de surpreender que a profundidade e a amplitude dessas EPANB variem de acordo com a capacidade dos países de empreender e implementar essas atividades. No entanto, apesar das variações nas EPANB, todas elas fornecem informações sobre a situação nacional da biodiversidade, ameaças, tendências, prioridades e ações estratégicas. Várias EPANB reconhecem o papel da restauração no apoio às metas nacionais e internacionais de biodiversidade e para países ou regiões que realizam avaliações de restauração da paisagem florestal, as EPANB podem ser tanto uma riqueza de informações específicas da espécie, como um ponto de partida para gerar interesse para as partes interessadas envolvidas no processo da EPANB (veja Fontes de dados de biodiversidade).

\section{Informações relevantes sobre biodiversidade das EPANB}

Como um processo internacional, o desenvolvimento de EPANB e o seu conteúdo é relativamente padronizado e normalmente inclui Fontes de Informações Gerais sobre Biodiversidade. Semelhante às avaliações de restauração da paisagem florestal, as EPANB identificam as partes interessadas, geografias e ações, muitas das quais são as mesmas que as das avaliações da FLR. Os resultados da política e da análise institucional da EPANB geralmente alinhar-se-ão com o mesmo processo numa avaliação da FLR e poderão, na verdade, incluir um número dos principais interessados diretos dentro de uma jurisdição. Portanto, seria sensato iniciar a avaliação da FLR com uma auditoria das políticas e leis mencionadas na EPANB e como elas podem estar

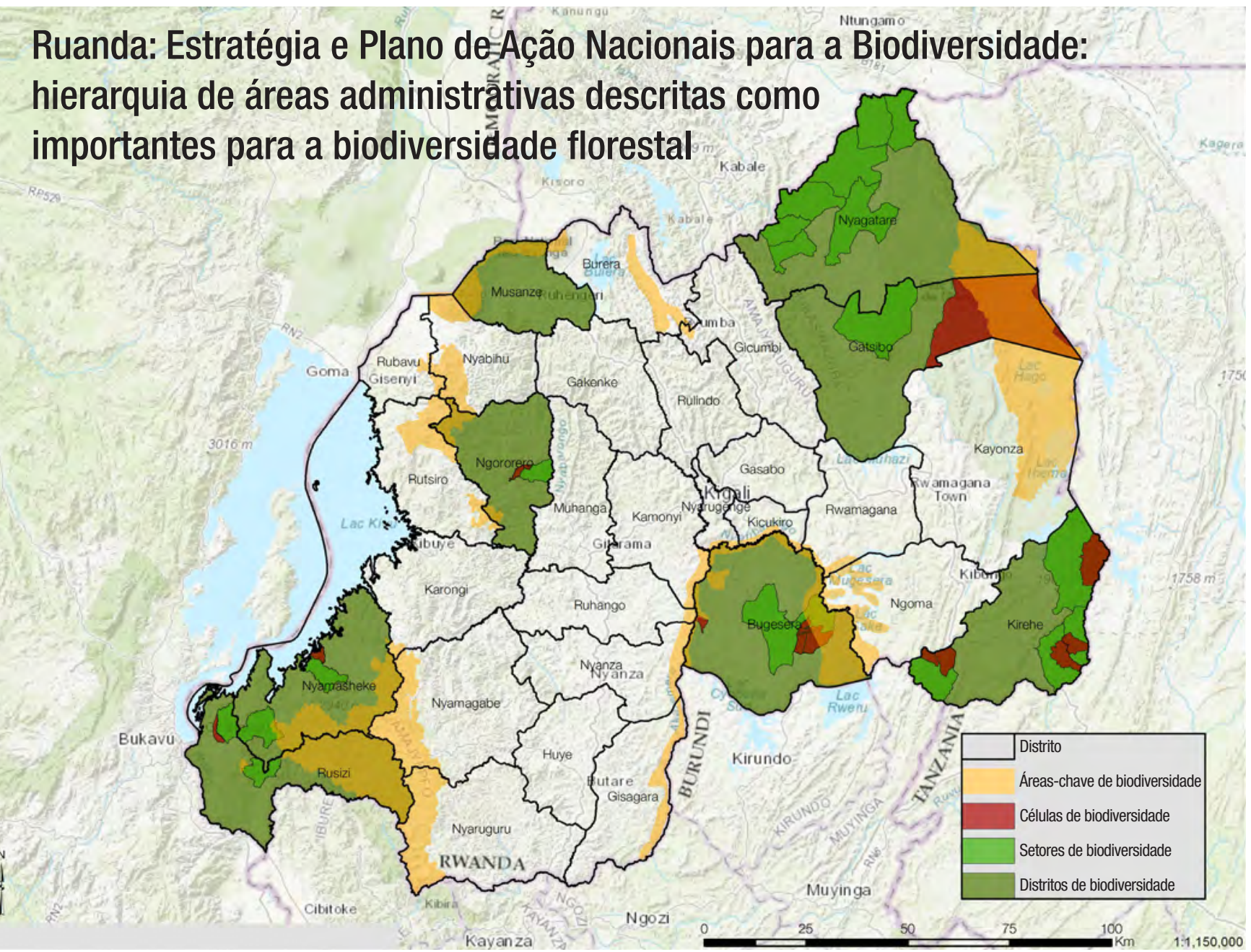

Figura 3 mostra os dados que foram extraídos da EPANB de Ruanda, que não continha mapas. As divisões administrativas de Ruanda são distritos, setores e células. Na EPANB, vários distritos são mencionados como áreas prioritárias para a biodiversidade e no interior de cada distrito são identificados habitats críticos que se referem explicitamente a subdistritos (setores) e/ou a células no interior destes (três níveis administrativos). Houve também situações em que florestas específicas foram mencionadas sem se nomear a divisão administrativa onde esses recursos se localizavam. Uma simples pesquisa na internet forneceu as informações necessárias para confirmar essas áreas administrativas. A partir dessa informação textual e desses dados espaciais da área administrativa, um analista GIS pode criar mapas nacionais de áreas prioritárias para a biodiversidade com base em hierarquias administrativas, e esses dados podem ser utilizados durante a análise espacial de oportunidades e prioridades de FLR. Além disso, esse processo analítico também pode ser concluído usando bacias hidrográficas, que podem representar com mais precisão os limites do ecossistema. 
relacionadas à FLR. As políticas setoriais que têm relação com a conservação da biodiversidade geralmente estão bem vinculadas às mesmas políticas que tratam das florestas e das paisagens, embora sejam frequentemente abordadas em diferentes seções dessas políticas.

As EPANB também estão repletas de informações geográficas sobre a situação e as tendências da biodiversidade. Muitas vezes essa informação é contextual e refere-se a recursos ou áreas geográficas onde a conservação da biodiversidade é especialmente importante. Embora a maioria das EPANB não contenha dados geoespaciais que as acompanhem, extrair essas informações do texto de uma EPANB é relativamente simples e fornece orientação adicional na identificação e integração de áreas importantes para a biodiversidade nas avaliações da FLR. O ponto focal nacional da CDB para a área em avaliação também pode auxiliar na obtenção destas informações.

Por fim, como um processo reconhecido internacionalmente por quase todas as nações, as EPANB receberam apoio significativo para a sua criação. Em cada país, os workshops ajudaram a reunir especialistas e as informações necessárias para formular as estratégias e ações indicadas nos planos. Em muitos casos, elas eram recentes o suficiente para que as plataformas institucionais e a equipa ainda estivessem relativamente intactas. As listas de grupos de trabalho e as listas de interessados estão prontamente disponíveis para acompanhamento pelos praticantes da FLR e geralmente são disponibilizadas como anexos aos documentos da EPANB. A equipa do governo que atualmente trabalha em avaliações da FLR frequentemente tem colegas dentro dos seus próprios departamentos ou ministérios que trabalharam no desenvolvimento da sua EPANB nacional. Identificar e comunicar-se com esses indivíduos sobre a avaliação da FLR em curso, proporcionará a oportunidade de integrar a biodiversidade e a restauração da paisagem florestal.

\section{Fontes de dados de biodiversidade}

\section{Conjuntos de dados históricos}

Para alguns países e regiões, a cobertura da terra/uso da terra (incluindo floresta e extensão do habitat associado) e a distribuição de espécies vêm sendo registados ou rastreados há décadas. Em muitos casos, os registos concentraram-se principalmente em recursos naturais vivos com valor comercial claro. Estes registos podem ser úteis para determinar a extensão anterior dos ecossistemas nativos, incluindo a antiga distribuição de espécies importantes (por exemplo, árvores de madeira) que podem formar uma parcela das futuras intervenções de restauração. Os registos históricos da distribuição de espécies animais podem ser valiosos para o processo de planeamento, especialmente se um dos alvos do processo de FLR é restabelecer as paisagens que dão apoio a estas espécies. O retorno natural de espécies extirpadas a uma paisagem restaurada pode ser usado como uma indicação geral de restauração bemsucedida.

\section{Lugares e espécies culturalmente importantes} Como parte de uma estratégia global para a restauração de paisagens e a sua componente de biodiversidade, é útil, tanto para o processo de restauração técnica

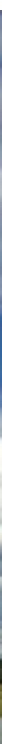


quanto para as interações com as comunidades locais, considerar espécies e locais culturalmente importantes dentro do processo de planeamento. Estas podem ser espécies ou locais que são importantes para propósitos religiosos ou espirituais, que tenham algum uso económico local (como para alimentos ou medicamentos de subsistência), ou podem ser áreas ou espécies agradáveis devido à sua beleza, valor intrínseco ou outro tipo de importância para as comunidades locais. As informações sobre espécies e locais de importância (como bosques sagrados) geralmente estão disponíveis apenas em escala local, e são colhidas da forma mais apropriada através da interação precoce com naturalistas e comunidades dentro das áreas de projetos propostas.

\section{Dados internacionais}

Além dos diversos e valiosos dados nacionais sobre biodiversidade e recursos de informação, existe uma gama substancial de dados padronizados sobre biodiversidade produzidos por organizações internacionais de conservação; muito desse material é útil durante as avaliações da FLR. A seguir, é apresentada uma lista parcial de alguns dos principais dados disponíveis que os praticantes de FLR podem considerar usar:

Lista Vermelha de Espécies Ameaçadas da UICN-A “Lista Vermelha" da UICN é a principal fonte mundial de dados sobre espécies ameaçadas e não ameaçadas (mais de 87 mil espécies estão documentadas). Informações detalhadas são frequentemente fornecidas na Lista Vermelha sobre a distribuição global de uma espécie (incluindo dados espaciais numa determinada faixa de espécies), tendências da população, habitat e requisitos ecológicos, ameaças à espécie, uso e comércio e necessidades de conservação. As informações da Lista Vermelha são usadas para determinar a situação da conservação global de cada espécie - a mesma pode variar de "Criticamente Ameaçada" (prioridade de conservação global) a "Menos Preocupante" (de preocupação de conservação menos imediata). Os dados estão disponíveis publicamente para uso não comercial e podem ser acedidos no seguinte site: http:// www.iucnredlist.org.

Áreas-Chave de Biodiversidade (KBA) - As KBA são locais identificados nacionalmente que são reconhecidos por contribuir para a persistência da biodiversidade. Critérios e limiares globalmente padronizados (divididos em cinco categorias: biodiversidade ameaçada; biodiversidade geograficamente restrita; integridade ecológica; processos biológicos; insubstituível) foram desenvolvidos para orientar a identificação de locais de conservação prioritários com limites definidos. As KBA estão a ser cada vez mais usadas para apoiar o planeamento de conservação e o desenvolvimento sustentável nos níveis nacional e regional. Agora estão incluídas nas KBA as Áreas Importantes para Aves e Biodiversidade (IBA) e Aliança para Extinção Zero (AZE), mais detalhadas abaixo. O Banco de Dados Mundial das Áreas-chave de Biodiversidade pode ser acedido no seguinte endereço: http://www.keybiodiversityareas.org/home.

Áreas Importantes para Aves e Biodiversidade (IBA) Desenvolvido pela BirdLife International, estes são locais que foram identificados como significativos para a persistência de espécies de aves. Foram catalogados

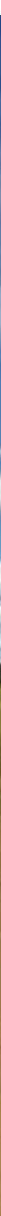


através de critérios internacionalmente padronizados, com mais de 12 mil IBA em mais de 200 países e territórios. Esses lugares também são reconhecidos como KBA para aves. Mais detalhes sobre IBA e o seu valor podem ser acedidos em: http://www.birdlife.org/ worldwide/programme-additional-info/important-birdand-biodiversity-areas-ibas.

Locais de Aliança para Extinção Zero (AZE) - A AZE é uma parceria de organizações não governamentais de conservação da biodiversidade que trabalha para prevenir a extinção de espécies, identificando e salvaguardando os locais onde espécies ameaçadas ou criticamente ameaçadas estão restritas a um único local remanescente. Grupos de espécies terrestres avaliados em relação aos critérios da AZE incluem mamíferos, aves, anfíbios, coníferas e alguns répteis, e outras espécies cujo trabalho ainda está em progresso. Informações adicionais sobre os lugares da AZE (incluindo um mapa global) podem ser localizadas no seguinte site: http:// www.zeroextinction.org.

Lista Vermelha de Ecossistemas da UICN (RLE) A RLE da UICN é interessante para os praticantes de restauração, especialmente na medida em que espera fornecer uma avaliação global do estado de conservação dos ecossistemas do mundo até 2025, com base na aplicação de uma série de categorias e critérios padronizados recentemente desenvolvidos.
Esse objetivo central foi estabelecido para dar apoio à conservação no que se refere ao uso de recursos e a decisões de gestão, identificando os ecossistemas com maior risco de colapso. Mais informações sobre a RLE da UICN e a sua cobertura geográfica atual podem ser obtidas em: https://iucnrle.org.

Banco de Dados Global de Espécies Invasoras (GISD) - Esta base de dados é mantida pelo Grupo de Especialistas em Espécies Invasoras da Comissão de Sobrevivência das Espécies da UICN. Ele contém detalhes pesquisáveis sobre espécies exóticas e invasoras que têmum impacto negativo na biodiversidade nativa e em áreas naturais, incluindo uma lista das "100 Piores Espécies Exóticas Invasoras do Mundo”. Embora compreensivelmente ainda não abrangente na cobertura da vasta gama de espécies invasoras em potencial, o GISD representa uma ferramenta extremamente útil ao se desenvolver um projeto de FLR, especialmente para a triagem inicial de espécies não nativas associadas à paisagem do projeto. Também é importante notar que nem todas as espécies exóticas introduzidas são invasoras. A Convenção sobre Diversidade Biológica define "espécies exóticas invasoras" como "plantas, animais, patógenos e outros organismos que não são nativos de um ecossistema e que podem causar danos económicos ou ambientais ou afetar negativamente a saúde humana". O banco de dados GISD pode ser pesquisado em: http://www.iucngisd.org/gisd.

\section{Evitando danos permanentes de espécies invasoras durante o planeamento da FLR}

Embora o uso de espécies nativas seja altamente recomendável sempre que possível, haverá muitos casos em que uma intervenção específica da FLR vai requerer a utilização de espécies não nativas - por exemplo, em situações em que árvores de rápido crescimento são necessárias e não existem alternativas nativas, ou quando a agrofloresta emergiu como uma solução baseada na natureza contra a degradação da paisagem. Nos casos em que o uso de espécies não nativas é planeado, deve-se ter muito cuidado para identificar espécies que não danifiquem a ecologia local, abrigando, ou tornando-as, espécies exóticas invasoras.

Espécies invasoras têm-se mostrado uma das ameaças mais comuns à biodiversidade nativa. Além dos problemas causados às espécies nativas (por exemplo, por predação, competição ou mudanças na estrutura do solo ou do substrato), espécies invasoras podem causar impacto nas comunidades locais, invadindo e danificando áreas agrícolas e outros locais economicamente viáveis. O custo de remoção de espécies invasoras pode ser extremamente alto e, em muitos casos, pode ser impossível erradicar totalmente as espécies exóticas invasoras, fazendo do controlo contínuo e oneroso da população a única opção viável de administração.

Embora seja necessário ter cuidado com as escolhas de vegetação (como árvores exóticas com potencial para se tornarem espécies invasoras), também é importante fazer escolhas sábias ao introduzir intencionalmente espécies animais. Todas as informações detalhadas colhidas pelo ecologista do projeto devem ser consideradas antes que quaisquer opções de introdução sejam analisadas. Assim como na vegetação, a introdução de espécies animais invasoras pode ser difícil de reverter e pode resultar em danos contínuos não apenas na área do projeto, mas também na paisagem, incluindo áreas vizinhas e ecossistemas. 
Banco de Dados Mundial de Áreas Protegidas (WDPA) - O acesso a esta base de dados disponível ao público, um projeto conjunto entre o PNUMA, o World Conservation Monitoring Centre (WCMC) e a UICN, é fornecido através da plataforma online "Protected Planet". Os dados espaciais, que incluem importantes locais de zonas húmidas RAMSAR, podem ser transferidos do site, incluindo a informação globalmente mais abrangente sobre a cobertura de áreas terrestres e marinhas protegidas. Estatísticas relacionadas e mais detalhes sobre o WDPA e o Protected Planet podem ser acedidos em: https://protectedplanet.net.

Ferramenta Integrada de Avaliação da Biodiversidade Embora este não seja um recurso primário no que se refere a dados de biodiversidade, trata-se de uma ferramenta valiosa que reúne várias camadas de dados globais e nacionais úteis para o planeamento da FLR, como limites de áreas protegidas (oriundos do WDPA), informações biológicas sobre habitats e índices de diversidade de espécies (fornecidos pela Lista Vermelha da UICN) e Áreas-chave de Biodiversidade no que se refere à biodiversidade (incluindo IBA e AZE previamente discutidos), que são úteis tanto para fins de planeamento de pesquisa e conservação como para guiar o desenvolvimento sustentável (especialmente ao gerir riscos e oportunidades de negócios). Estes dados estão disponíveis em dois sites - IBAT para
Pesquisa e Planeamento de Conservação (https:// www.ibat-alliance.org/ibat-conservation), que fornece acesso a informações livremente disponíveis, e IBAT para Negócios (https://www.ibatforbusiness.org), o qual requer uma taxa para o uso comercial dos extensos dados de biodiversidade.

\section{Políticas e informação institucional sobre biodiversidade}

Durante uma avaliação de FLR, uma das principais atividades é uma análise do grau em que as políticas, leis, códigos e instituições existentes permitem ou desencorajam a restauração da paisagem florestal. As políticas e leis nacionais relacionadas especificamente à biodiversidade têm sido bem resumidas na Estratégia e Plano de Ação Nacionais para a Biodiversidade (EPANB). Como resultado, os tipos de leis e políticas descritas nas EPANB podem refletir políticas que se referem especificamente a espécies ameaçadas, comércio e áreas protegidas para conservação, sem ter uma visão mais ampla das implicações sociais ou da dependência da biodiversidade. Outras políticas, planos e estratégias identificados durante o processo de avaliação que são relevantes para a FLR referem-se ao uso de recursos naturais, regimes de posse da terra e conflitos, e questões jurisdicionais e de posse. Uma vez que muitas dessas

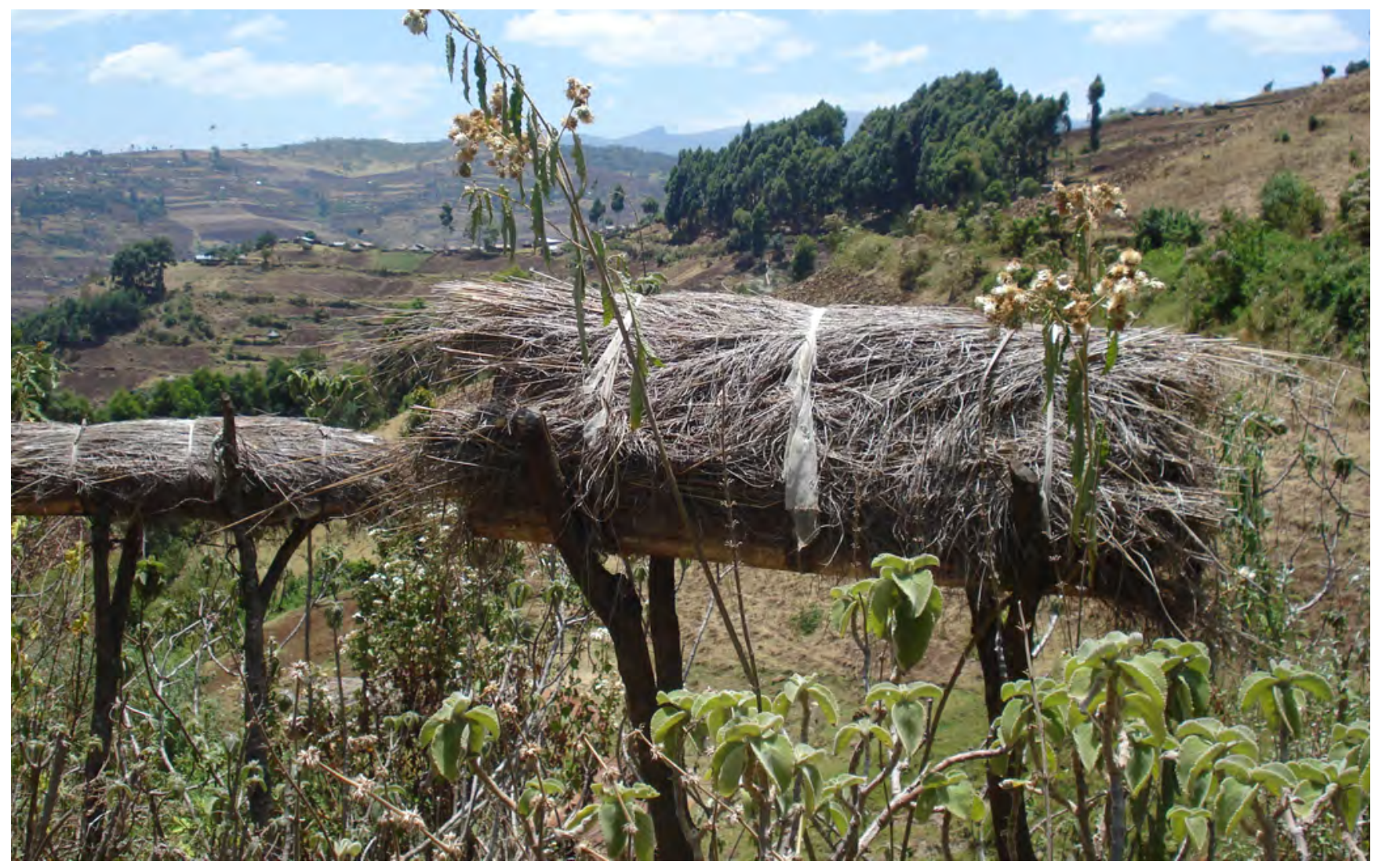

Colmeias produzem mel que pode ser uma mercadoria não-lenhosa e não agrícola valiosa, ao mesmo tempo que apoia aumentos na polinização.As comunidades e as abelhas dependem da biodiversidade da paisagem nas encostas do Monte Elgon no Distrito de Bukwo em Uganda. Foto de Craig Beatty/UICN 
políticas podem inerente ou especificamente lidar com o acesso a recursos naturais, há uma componente de biodiversidade inerente a cada uma delas e a maioria fornece informações adicionais sobre a dependência social dos recursos naturais e do capital.

A restauração da paisagem florestal pauta-se por uma visão da conservação da biodiversidade que inclui espécies e ecossistemas que podem não estar atualmente ameaçados, mas que fornecem as condições críticas para a restauração de paisagens multifuncionais. À medida que a biodiversidade diminui, as espécies e os ecossistemas ficam cada vez mais em risco, resultando em degradação da paisagem em larga escala. Para entender melhor o ambiente propício para a FLR, que também pode maximizar os resultados da biodiversidade, é necessário entender melhor as políticas e os planos que afetam a paisagem mais ampla. A análise das estratégias, leis, políticas e planos da FLR que afetam a área de avaliação em questão fornecerá orientação crítica para a superação dos gargalos para a implementação bem-sucedida da FLR. Isso pode incluir a identificação de políticas conflituosas ou políticas que podem impactar desproporcionalmente um setor em detrimento de outro. Este é um processo que normalmente é realizado por um grupo de trabalho de "políticas e instituições" dentro da estrutura de avaliação da FLR, mas um profissional da biodiversidade que esteja confortável em traduzir tais políticas (por exemplo, política agrícola ou comercial) de acordo com o seu impacto na biodiversidade melhorará drasticamente o reconhecimento e a integração da biodiversidade na FLR. Uma análise do ambiente propício para a FLR pode fornecer uma visão clara dos (des)incentivos para restaurar e conservar que existem para as partes interessadas na paisagem, e essa análise pode ajudar a fornecer recomendações para uma abordagem holística e coesa da biodiversidade e da FLR.

Uma das dificuldades para o praticante pode ser as diferenças nas fronteiras legais e jurisdições entre as várias leis e políticas relacionadas à FLR e nas EPANB, por exemplo. As EPANB baseiam-se predominantemente em áreas protegidas, enquanto muitos dos outros instrumentos legais que cercam a FLR consideram jurisdições como províncias, distritos ou comunidades. Extrair e interpretar essa informação necessária, no nível administrativo ou político correto, para a avaliação da FLR, continua a ser um desafio. Esta dificuldade pode ser ainda agravada pela falta de consideração geral da biodiversidade em políticas e planos de uso da terra, económicos, de desenvolvimento ou de FLR existentes. Como resultado, a biodiversidade - que pode não ser uma prioridade para a conservação (EPANB), e tão pouco catalogada em outras políticas e planos, incluindo em termos de valor específico de exportação de recursos naturais - pode ser negligenciada. Uma vez que a biodiversidade e os serviços ecossistémicos são regularmente subvalorizados como bens públicos, políticas e leis que apoiam o papel da biodiversidade na restauração de paisagens funcionais geralmente ficaram atrás de objetivos políticos projetados para catalisar o crescimento económico (Arrow et al. 1995, Kumar et al. 2013). A subvalorização da biodiversidade e dos

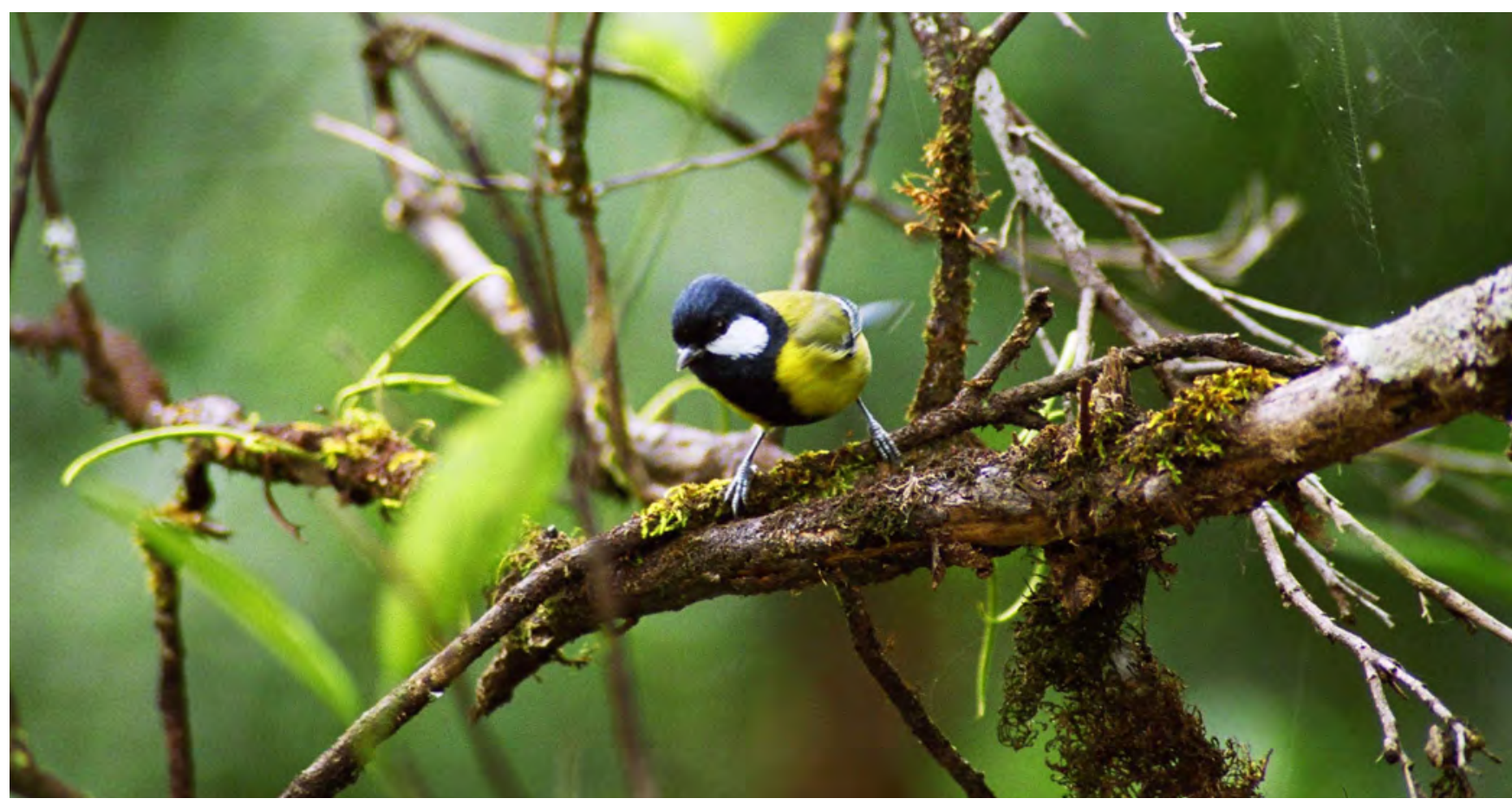

A presença de espécies de aves pode ser um importante indicativo do sucesso da restauração. Muitas espécies têm requisitos rigorosos de habitat, mas a presença contínua de espécies generalistas é também um sinal de que as paisagens podem não se degradar ainda mais. Além disso, os chamados "avistamentos" de aves são relativamente simples para monitorar pelo menos uma componente da biodiversidade. Melharuco de dorso verde (Parus monticolus), Sikkim, Índia. Foto cedida por Akshay Vishwanath. 
serviços ecossistémicos, por sua vez, leva a baixos investimentos em restauração da paisagem, apesar dos seus numerosos e diversos benefícios.

Além disso, cada uma das metas típicas da FLR tem uma ampla base de leis e instituições que a apoia, especialmente porque essas metas apoiam objetivos que estão mais diretamente ligados ao bem-estar social. A vontade política e o movimento por temas como saúde pública e alívio da pobreza, são relativamente bem estabelecidos e financiados, e é claro que ambos os objetivos estão intimamente ligados a paisagens saudáveis (Herrera et al., 2018). A restauração, a manutenção e a conservação da biodiversidade da paisagem - independentemente da conservação, mas também reconhecendo o valor dela - são a chave para se alcançar um progresso significativo e sustentável nessas metas.

Um aspecto especialmente útil do desenvolvimento da EPANB é a identificação, desenvolvimento e aperfeiçoamento de políticas públicas para dar apoio à conservação da biodiversidade.

Por extensão, muitas políticas desenvolvidas para a conservação da biodiversidade também têm relação com a restauração de paisagens degradadas. Em alguns casos, as ações de restauração podem ser obrigadas a incluir um patamar de espécies de plantas nativas usadas no processo de restauração. Noutros casos, os tipos de restauração que podem ser implementados podem ser definidos pelas leis que foram aprovadas para dar apoio à conservação da biodiversidade ou para limitar a disseminação de espécies invasoras. A análise de políticas públicas e leis que foram desenvolvidas durante o processo da EPANB, e de como elas se podem relacionar com políticas e leis semelhantes para a FLR, pode levar a alinhamentos eficientes das políticas existentes e das lacunas das políticas.

Os praticantes da FLR devem procurar modificar as políticas públicas que prejudicam as iniciativas de restauração da paisagem florestal para assegurar que quaisquer ações restaurativas adotadas em terras degradadas sejam apoiadas política e institucionalmente. Embora muitas vezes seja uma tarefa substancial, a modificação da legislação nacional ou subnacional para apoiar a restauração da paisagem e/ou a conservação da biodiversidade, ocorreu em muitos países e levou a resultados positivos para as pessoas e para a natureza. Abordar e modificar políticas públicas ajuda a garantir que as soluções intermediadas pelo processo de avaliação da FLR, orientado pelas partes interessadas e as estratégias resultantes, encontrem uma base para implementação que possa resistir aos ciclos políticos e beneficiar-se da visão de longo prazo para a restauração sustentável e efetiva da paisagem.

\section{Dados de biodiversidade em mapeamento e análise espacial}

A chave no alinhamento entre informações sobre biodiversidade e avaliações de FLR para apoiar iniciativas de conservação e restauração de paisagens, como o REDD+ e o Desafio de Bonn, é a avaliação analítica de onde e como as informações sobre restauração e biodiversidade interagem. As avaliações para a conservação da biodiversidade, normalmente através das EPANB, mas também através de outros programas e iniciativas de conservação, contêm uma riqueza de dados geográficos sobre biodiversidade, habitat e paisagens. Da mesma forma, as avaliações de FLR também recolhem e analisam dados espaciais para identificar os vetores de degradação da paisagem e áreas de oportunidade, para a restauração na escala da paisagem em muitos usos diferentes da terra. Um dos principais objetivos deste documento de orientação é facilitar a cooperação e a partilha de dados/ conhecimentos entre esses processos complementares.

Entre as fontes nacionais, regionais e globais de informação sobre biodiversidade, existem muitas fontes de informação espacial bem documentadas e respeitadas sobre espécies, habitats e ecossistemas. Globalmente, a Lista Vermelha de Espécies Ameaçadas da UICN exige que todas as contagens de espécies ameaçadas publicadas contenham faixas de distribuição. Além disso, tem havido várias avaliações globais de ecossistemas e ecorregiões, incluindo o US Geological Survey ${ }^{2}$ e o WWF/ TNC. $^{3} \mathrm{O}$ foco global na monitoria da perda florestal e mudanças no uso e cobertura da terra também levaram ao uso de deteção remota de dados por satélite, que pode fornecer informações úteis e em tempo real sobre a perda de florestas e a mudança da cobertura da terra, que não deve entrar em conflito com a monitoria da biodiversidade em si, mas fornece informações úteis e que podem ser acionadas, sobre a paisagem. Medir e avaliar a biodiversidade num contexto de FLR são ações que devem aproveitar esses conjuntos de dados globais, bem como os dados de biodiversidade nacionais ou de grande escala descobertos durante o início da avaliação.

O processo de avaliação da FLR deve ter como um dos seus resultados mapas que indiquem onde a terra está degradada (muitas vezes incluindo análises da intensidade dessa degradação), onde a restauração é possível e quais as oportunidades de restauração que podem existir. Em cada um desses produtos, podem ser usadas informações sobre biodiversidade

2. https://rmgsc.cr.usgs.gov/ecosystems

3. https://www.worldwildlife.org/biome-categories/terrestrial-ecoregions 
para ajudar a definir, dar prioridade ou refinar áreas que apresentam alto potencial para a implementação de atividades de restauração da paisagem florestal. Locais onde a biodiversidade está sob ameaça podem ser incluídos na análise espacial como um tipo de filtro para hierarquizar por prioridade, dando maior peso aos locais que recebem maiores pressões de degradação. $O$ praticante de FLR deve localizar áreas degradadas onde a sua implementação beneficiaria a paisagem e a sua população e onde essas áreas se sobrepõem a áreas que também são altamente prioritárias para a biodiversidade.

De forma alternativa, uma vez que a maioria dos dados de biodiversidade estará relacionada à presença ou à ausência de espécies ou outros critérios de biodiversidade, a integração desses dados nas avaliações espaciais de terras degradadas, áreas prioritárias e oportunidades de FLR é um exercício relativamente direto. Os dados de biodiversidade são tipicamente dados de presença geográfica e é raro encontrar dados espaciais que abranjam toda uma área de avaliação de FLR que também inclua atributos de biodiversidade como riqueza de espécies ou índices de diversidade (por exemplo, índice de Shannon ou Índice de Simpson). Apesar disso, o planeamento de conservação e a construção de modelos de adequação de habitat são possíveis usando ferramentas familiares aos biólogos ou ecologistas de conservação (por exemplo, NatureServe Vista, Maxent, Marx, Zonation, VORTEX, RAMAS, BIOMOD etc.). Quando fornecidos com o contexto de espécies apropriado, esses tipos de modelos podem ser úteis para ilustrar como as espécies podem responder à restauração.

Para efetivamente mapear a prioridade da biodiversidade usando os recursos de dados mencionados acima, o analista espacial deve contatar os provedores de dados usando os contatos listados em Fontes de Dados de Biodiversidade. Uma vez que os dados são adquiridos, eles podem ser analisados separadamente como uma análise de biodiversidade ou podem ser integrados na parte mais ampla da análise de dados da avaliação da FLR. Aescolha dependerá dos objetivos e expectativas do grupo de trabalho e das partes interessadas da avaliação da FLR. Se a biodiversidade é uma consideração-chave incluída como meta para a FLR, pode fazer sentido concluir uma análise de biodiversidade autónoma e usar os resultados dessa análise para ajudar a informar ou dar prioridade a outras análises (por exemplo, degradação, segurança alimentar, resiliência etc.). No entanto, se a restauração da biodiversidade não for uma meta explícita da avaliação da FLR, pode fazer sentido incluir esses dados como componentes da avaliação da FLR subjacente. Isso significa incluir dados de biodiversidade como um dos muitos critérios numa análise multicritério, ou usar dados de biodiversidade como uma aproximação para outros processos biofísicos ou sociais que são de interesse para a avaliação da FLR.

A verificação da dinâmica ecológica e o fluxo na avaliação dos dados de biodiversidade para a FLRéa consideração final a ser feita na análise espacial. Embora os dados

\section{Análise multicritério para biodiversidade em avaliações de FLR}

A análise espacial dos dados de biodiversidade numa estrutura de análise multicritério é relativamente simples. $\mathrm{O}$ analista de dados espaciais deve adquirir cada um dos tipos de camada de dados relevantes, garantir que eles estejam em formato raster e trabalhar com os interessados na definição de parâmetros, de forma a incluir dados que sejam interessantes na análise. A definição de parâmetros dos dados espaciais de biodiversidade pode incluir a remoção de faixas de espécies para espécies que são consideradas "menos preocupantes" ou a seleção de uma determinada taxonomia que seja de interesse para as partes interessadas ou praticantes de restauração. Além disso, pode incluir a extração de áreas com uma cobertura específica mínima ou ecorregiões que tenham demonstrado prioridade ou valor de conservação.

O analista então reclassifica esses dados em rasters binários, onde "1" é igual ao parâmetro de biodiversidade que o analista acha interessante e "0" inclui todas as outras áreas dentro da extensão raster. É possível atribuir diferentes pesos às camadas de entrada durante a reclassificação, mas a discussão dos pesos apropriados pode tornar-se demorada entre os parceiros do projeto e as partes interessadas. É mais simples discutir os parâmetros apropriados para cada camada com as partes interessadas.

O analista então direciona o GIS para executar a álgebra de mapas aditivos usando as camadas binárias de rasterização de entrada que foram definidas como parâmetros e reclassificadas. O resultado mostrará onde os critérios de biodiversidade se sobrepõem e em que grau. Neste processo, deve-se ter cautela para reduzir o potencial de sobreposição de dados que são elementos da análise. Um exemplo frequente disso na análise da biodiversidade é a sobreposição entre as KBA e as áreas protegidas. A utilização dessas duas camadas numa análise multicritério da biodiversidade, sem reconhecer a sua autocorrelação, levará à contagem dupla dessas áreas. 
$\mathrm{Na}$ figura abaixo, quatro critérios gerais de biodiversidade foram usados para avaliar a biodiversidade para inclusão na Avaliação e Estratégia de Restauração da Paisagem da Floresta Nacional do Maláui. A cobertura de árvores "altas" foi determinada usando uma cobertura de dossel mínima de $40 \%$ como limite. As partes interessadas também queriam identificar as áreas protegidas fora das Áreas-Chave de Biodiversidade atualmente identificadas e as Áreas-Chave de Biodiversidade fora das áreas protegidas atuais. Devido à natureza da avaliação, as áreas protegidas não foram incluídas nesta análise, conforme explicado no documento de Avaliação Nacional. Por fim, as ecorregiões designadas como "ameaçadas" ou "criticamente ameaçadas" foram incluídas como contribuições. Quando sobrepostas umas às outras, elas produzem o mapa de cores, que mostra onde os critérios de entrada são coincidentes.

$\mathrm{Na}$ avaliação nacional de FLR do Maláui, foi determinado que, se menos de $10 \%$ do compromisso nacional deste país com a FLR, no âmbito do Desafio de Bonn, fosse implementado a partir de abordagens que dessem prioridade à restauração usando espécies nativas e apoiando ecossistemas naturais, o Maláui poderia restaurar todas as suas terras degradadas dentro das suas Áreas-Chave de Biodiversidade. Isto levaria potencialmente a enormes ganhos nacionais no Maláui para os seus compromissos no âmbito da Convenção sobre Diversidade Biológica.
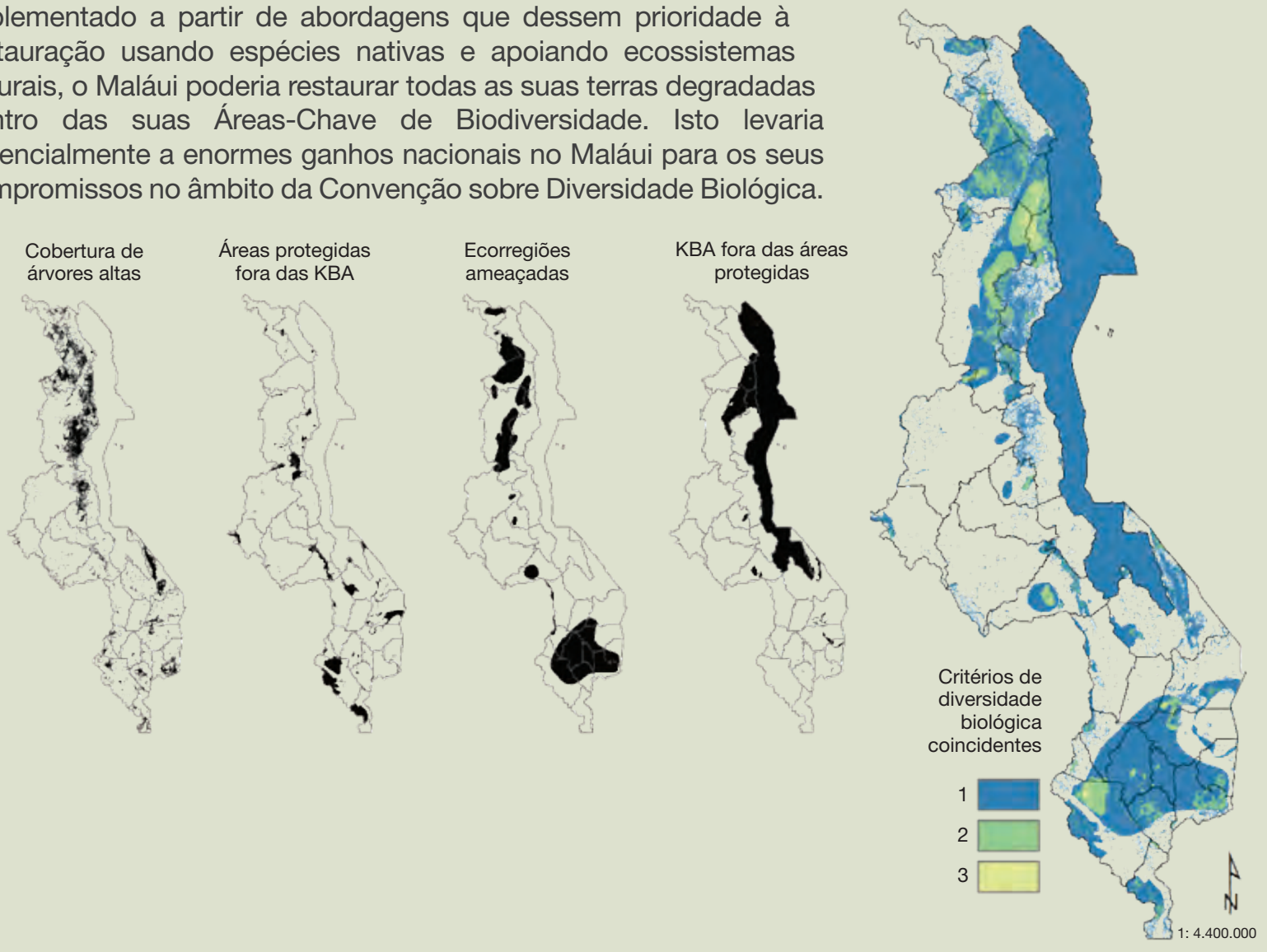

espaciais sejam estáticos, os ecossistemas, espécies e genes são dinâmicos, e a proximidade de áreas de biodiversidade importantes uma para a outra confere um nível adicional de consideração a se fazer ao mapear prioridades de biodiversidade para FLR; a configuração de fragmentos de habitats remanescentes, cursos de água ou populações pode aumentar a prioridade dessas áreas para a restauração da biodiversidade. Se houver dados disponíveis, recomenda-se que os profissionais de biodiversidade analisem as tendências de espécies e a dinâmica populacional ao longo de várias gerações de espécies para a sua inclusão na análise de dados espaciais das avaliações de FLR. Isto também fornecerá informações mais robustas para dados de referência e valores de referência para monitorar o impacto de FLR na biodiversidade.
Também pode ser relevante ter em consideração como as faixas de espécies se podem alterar devido a mudanças no clima ou aos efeitos derivados das mudanças climáticas. Há pelo menos um caso moderno confirmado de extinção de mamíferos devido à mudança climática (Waller et al., 2017), e a influência das mudanças climáticas, incluindo os impactos, sobre as espécies, do aumento do nível do mar, é real e está a evoluir (Thomas et al. 2004; Wetzel et al., 2013). Estes impactos podem incluir contrações de intervalo ou reduções na população, além de alterações mais amplas no ecossistema devido a mudanças nas relações entre espécies, os impactos de espécies exóticas invasoras ou cascatas tróficas indeterminadas. É claro que, quando se considera a FLR no contexto das mudanças climáticas, a inclusão 
da biodiversidade deve não apenas considerar as condições ecológicas atuais, mas também prever as condições ecológicas futuras, sempre que possível. Isso permite a seleção de espécies de restauração que podem ser mais resistentes a mudanças no clima e nos padrões climáticos. A utilização de uma diversidade de espécies na restauração também ajuda a isolar grandes investimentos em projeto, planeamento e implementação de atrito devido a mudanças ambientais imprevisíveis. Várias ferramentas, incluindo o Índice de Vulnerabilidade às Mudanças Climáticas, ${ }^{4}$ desenvolvido pela NatureServe, podem ser instrumentos para a construção de modelos de como as mudanças climáticas podem afetar as espécies. Além disso, o Grupo de Especialistas em Mudanças Climáticas da Comissão de Sobrevivência de Espécies da UICN (https://iucn-ccsg.org/) poderá fornecer recursos e informações adicionais sobre a suscetibilidade das espécies às mudanças climáticas e recomendações para melhorar a conservação de espécies sob condições climáticas em mudança.

\section{Identificação das lacunas de biodiversidade}

Apesar da crescente riqueza de informações confiáveis sobre biodiversidade de fontes de dados nacionais e internacionais, é provável que, em muitos locais, haja lacunas substanciais no conhecimento sobre quais espécies e comunidades ecológicas existiam no local antes da sua degradação. Em muitos casos, haverá poucos registos sobre a composição de espécies das antigas paisagens (especialmente para invertebrados, fungos e alguns grupos de plantas), no entanto, a falta de informações disponíveis não pode impedir os esforços de restauração. Se surgirem informações adicionais sobre a presença anterior de uma espécie no local durante a restauração da paisagem, pode ser realizada uma avaliação para determinar se as populações desta espécie devem ser incluídas no trabalho em andamento ou incluídas no futuro talvez esse seja o caso especialmente de espécies de árvores ou espécies-chave de animais que realizam benefícios ecológicos substanciais e que dão suporte à persistência de muitas espécies adicionais no interior da paisagem (como a dispersão de sementes de árvores).

Uma das lacunas mais gritantes que se segue à avaliação da biodiversidade nas avaliações de FLR é a relativa escassez de sementes nativas e de reservas de mudas para atividades de restauração (Jalonen et al, 2017). Em todo o mundo, as iniciativas de FLR geralmente recomendam que espécies nativas sejam plantadas e usadas em atividades de restauração, e isso geralmente recebe amplo apoio. No entanto, na maioria dos locais, as espécies nativas não são amplamente cultivadas e há uma lacuna dramática nas ambições de restauração da biodiversidade nativa e a reserva física e genética para atingir essas ambições(Haase e Davis, 2017). Duranteuma avaliação de FLR, será necessário solicitar uma auditoria das fontes potenciais de sementes e mudas dentro da área de avaliação, geralmente com a ajuda de viveiros e jardins botânicos, caso existam. Em alguns casos, a falta de sementes e mudas nativas pode representar uma barreira para intervenções eficazes de FLR usando espécies nativas. Embora, noutros casos, isso possa representar uma oportunidade comercial valiosa para as áreas rurais colherem e fornecerem sementes e mudas nativas para intervenções de restauração pendentes, como aconteceu em vários países (Urzedo et al., 2017; De Vitis et al., 2017).

\section{Consideração da biodiversidade em avaliações e planeamento de FLR}

Como centenas de milhões de hectares de terras degradadas estão comprometidas com a restauração da paisagem, torna-se cada vez mais importante que os praticantes da FLR estejam informados e compreendam as muitas perspectivas das paisagens em que estão a trabalhar. Os planos para intervenções de restauração devem ser modificados e implementados dentro do contexto da paisagem, de modo que a restauração apoie o aumento do bem-estar humano e que o valor geral da biodiversidade não diminua por causa da atividade de restauração.

Na implementação da FLR, o praticante emprega um conjunto de estratégias de restauração, que inclui a restauração ecológica tradicional. É importante ressaltar que a FLR não defende mudanças de grande escala no uso predominante da terra, mas sim a restauração de paisagens degradadas e desmatadas e o ajuste do uso atual da terra aos princípios da FLR. Ao mesmo tempo, as compensações precisam ser levadas em consideração, o que pode levar a mudanças no uso da terra. Por exemplo, enquanto a agrossilvicultura pode ser uma intervenção importante da FLR, aquela pode não ser uma estratégia de intervenção apropriada em áreas com um alto valor de biodiversidade existente. Além disso, a restauração ecológica em áreas com baixíssimo valor de biodiversidade é tipicamente proibitiva em termos de custo e esforço.

Uma estimativa de como a restauração pode afetar a biodiversidade nativa deve ser um resultado-chave de qualquer avaliação de oportunidades de restauração

4. http://www.natureserve.org/conservation-tools/climate-change-vulnerability-index 
da paisagem. Através da análise de informações espaciais e não espaciais da biodiversidade no interior de uma área de avaliação, o praticante da FLR deve adquirir uma boa compreensão das prioridades de biodiversidade de uma paisagem, juntamente com as avaliações de degradação e os seus vetores. O objetivo de salvaguardar a biodiversidade é "não causar dano" ao se implementar ações de restauração, mas a intenção é usar a restauração para melhorar os resultados da biodiversidade. Em termos de biodiversidade, isso pode ser alcançado, através da restauração, de duas maneiras:

Em primeiro lugar, a restauração das paisagens para aumentar a produtividade e apoiar os meios de subsistência humanos, tem o potencial de diminuir a pressão sobre a biodiversidade. A restauração que melhora as condições da paisagem e a produtividade agrícola e proporciona outros benefícios sociais pode levar a menos pressões em áreas de alta biodiversidade e reduzir ou evitar a exploração excessiva dos recursos naturais. Em muitos lugares, os ecossistemas saudáveis fornecem os serviços ecossistémicos necessários e a rede de segurança social para a sobrevivência dos pobres das áreas rurais. Além disso, a FLR pode tornar as paisagens mais biodiversas em geral, à medida que as espécies de árvores, plantas e culturas na área de avaliação aumentam ao se implementarem estratégias de restauração.
Segundo: intervenções apropriadas de restauração em áreas degradadas que são especificamente importantes para a biodiversidade, têm o potencial de ajudar as espécies a se recuperarem e aumentar os resultados da biodiversidade na escala da paisagem. Este é o caso especialmente de áreas que são classificadas na análise como degradadas, mas existem dentro de áreas protegidas ou das Áreas-Chave de Biodiversidade (KBA). A restauração dessas áreas, especialmente com a restauração ecológica em mente ou como um componente, ajuda a melhorar e a manter a integridade e a ligação entre essas paisagens. Isso também se estende ao efeito da restauração da paisagem sobre a qualidade da água e dos cursos de água, que frequentemente representam áreas onde as intervenções de FLR não são fisicamente possíveis, mas que podem ver melhorias drásticas como resultado de ações de restauração.

Alguns recursos adicionais para assegurar que as atividades de restauração deem suporte à biodiversidade incluem as Salvaguardas Ambientais e Sociais do Banco Mundial (Capítulo 6), Padrão de Desempenho 6 da IFC: Conservação da Biodiversidade e Gestão Sustentável de Vida. Recursos Naturais (PSS 6), Padrões Internacionais da Sociedade para Restauração Ecológica para a Prática de Restauração Ecológica, Caixa de Ferramentas da Bioversidade para Sistemas de Sementes Resilientes e Diretrizes sobre Negócios e KBA, desenvolvidas pelos Parceiros das Áreas-chave de Biodiversidade.

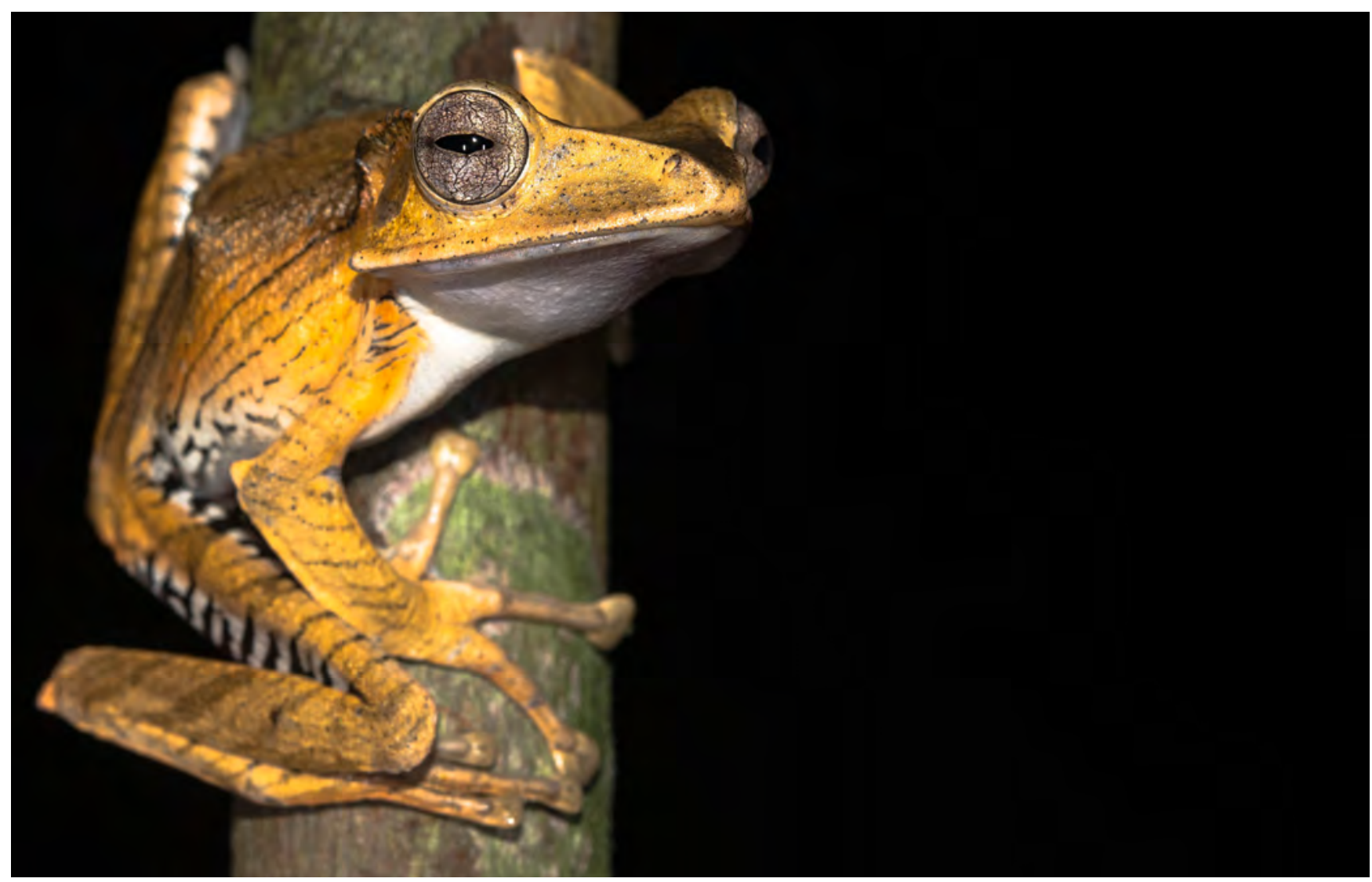

Uma rã de árvore orelhuda (Polypedates otophilus) da ilha de Bornéu. Foto cedida por Philip Bowles 


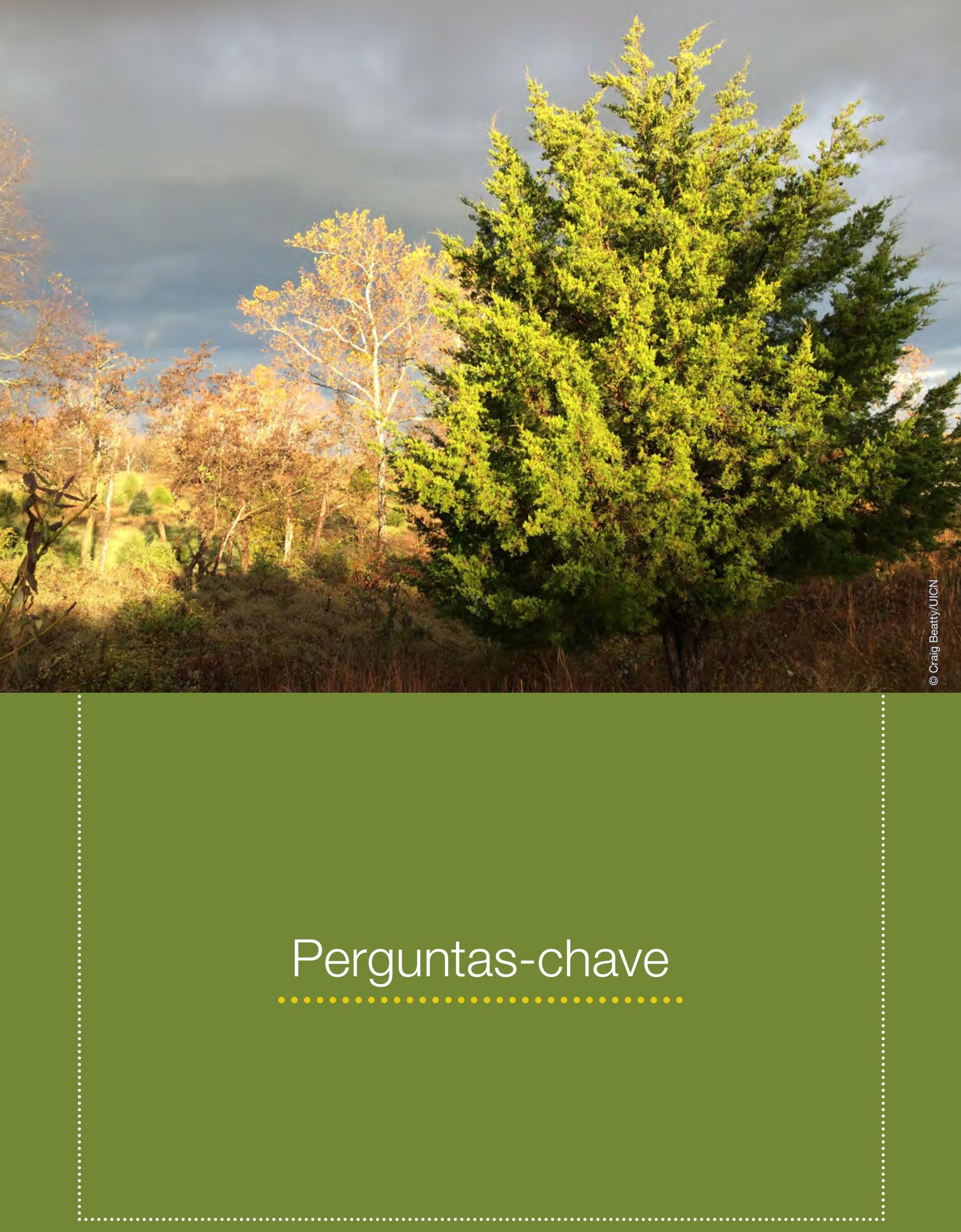




\section{Onde, ou como, a biodiversidade é distribuída dentro da área de avaliação? Os dados sobre biodiversidade estão disponíveis ou acessíveis?}

A triagem inicial das distribuições de biodiversidade pode ser realizada usando os conjuntos de dados de biodiversidade descritos anteriormente (para espécies ameaçadas e não ameaçadas). Esses dados incluem informações espaciais disponíveis publicamente para uma gama cada vez maior de espécies. A sobreposição dos mapas de alcance para essas espécies (ou áreas de prioridade de conservação) pode fornecer um guia geral sobre como as espécies são potencialmente distribuídas dentro da área de avaliação. É importante que os conjuntos de dados locais sejam incluídos no processo de revisão, se disponível. Além de conter informações sobre espécies adicionais incluídas em conjuntos de dados regionais ou globais até o momento, em muitos casos, eles terão dados mais específicos sobre os locais onde espécies prioritárias foram registadas. Além disso, é importante notar que, sempre que possível, quaisquer dados históricos sobre a mudança no uso da terra (especialmente onde a distribuição da biodiversidade é discutida) serão importantes para o planeamento do trabalho de restauração.

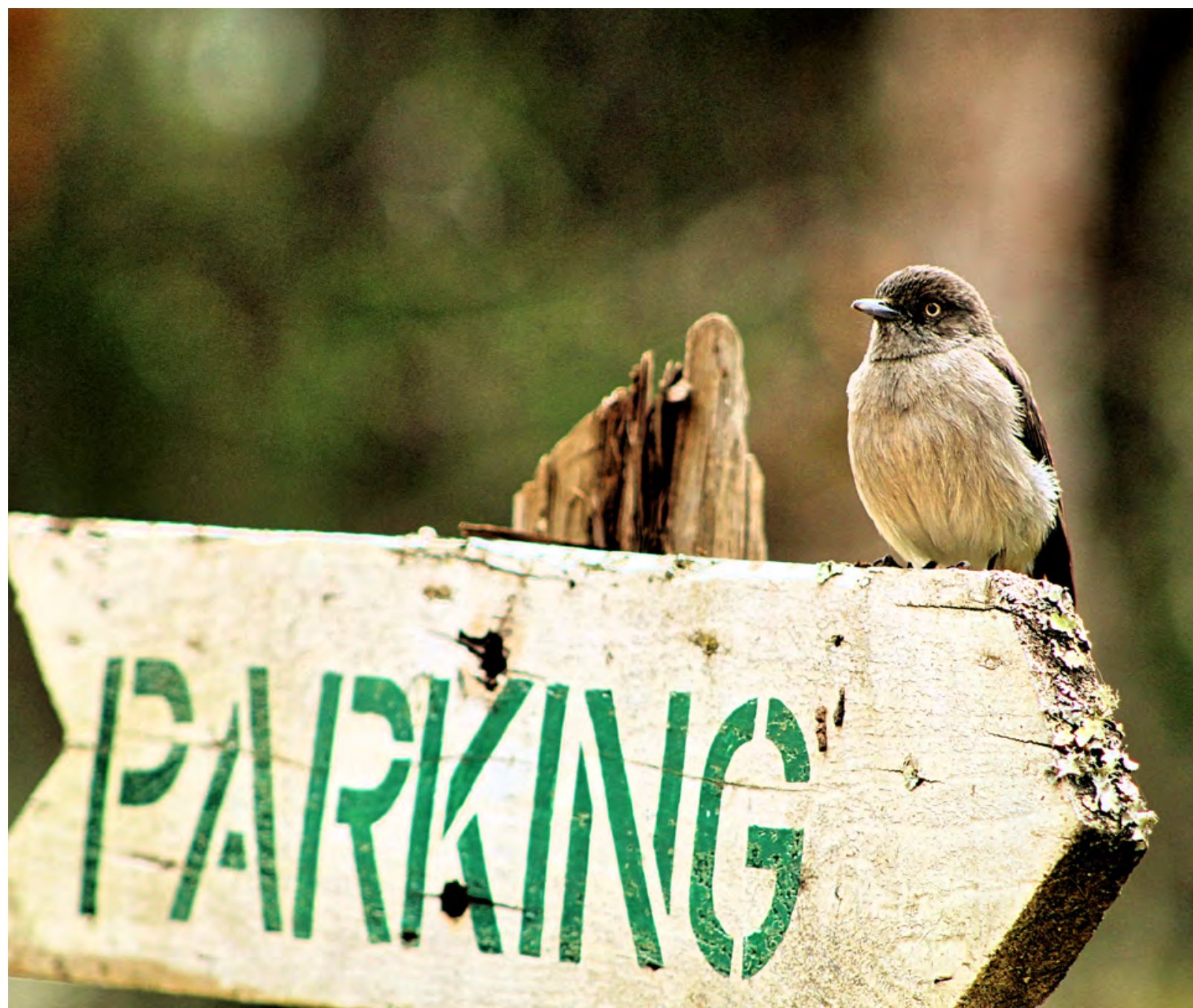

Um papa-moscas-da-pradaria abissínio (Melaenornis chocolatinus) empoleira-se num pouco de líquen na floresta de Suba, em Oromia, Etiópia. Foto cedida por Craig Beatty/UICN 


\section{Existem áreas geográficas às quais devem ser dada prioridade para a restauração porque essa atividade terá claro benefício local para as pessoas e para a natureza?}

Ao analisar as áreas potenciais numa paisagem para atividades de restauração, haverá uma gama de opções para se iniciar o trabalho de FLR. Áreas de vegetação nativa antiga que estão agora muito degradadas e com pouco uso, são claramente locais que geralmente se beneficiariam das intervenções da FLR, tanto para as pessoas quanto para a natureza. A identificação de terras degradadas próximas a áreas existentes de vegetação nativa é um bom primeiro passo para um planeamento mais específico das atividades da FLR que beneficiam a biodiversidade ou permitem estratégias de regeneração natural de terras degradadas adjacentes. A restauração dessas terras, em princípio, deve permitir a expansão das espécies desejáveis que estão atualmente confinadas às áreas remanescentes do habitat (embora a recolonização de locais de restauração para algumas taxonomias possa ser um processo lento), ao mesmo tempo que fornece serviços ecossistémicos mais amplos para as pessoas que dependem da paisagem em restauração.

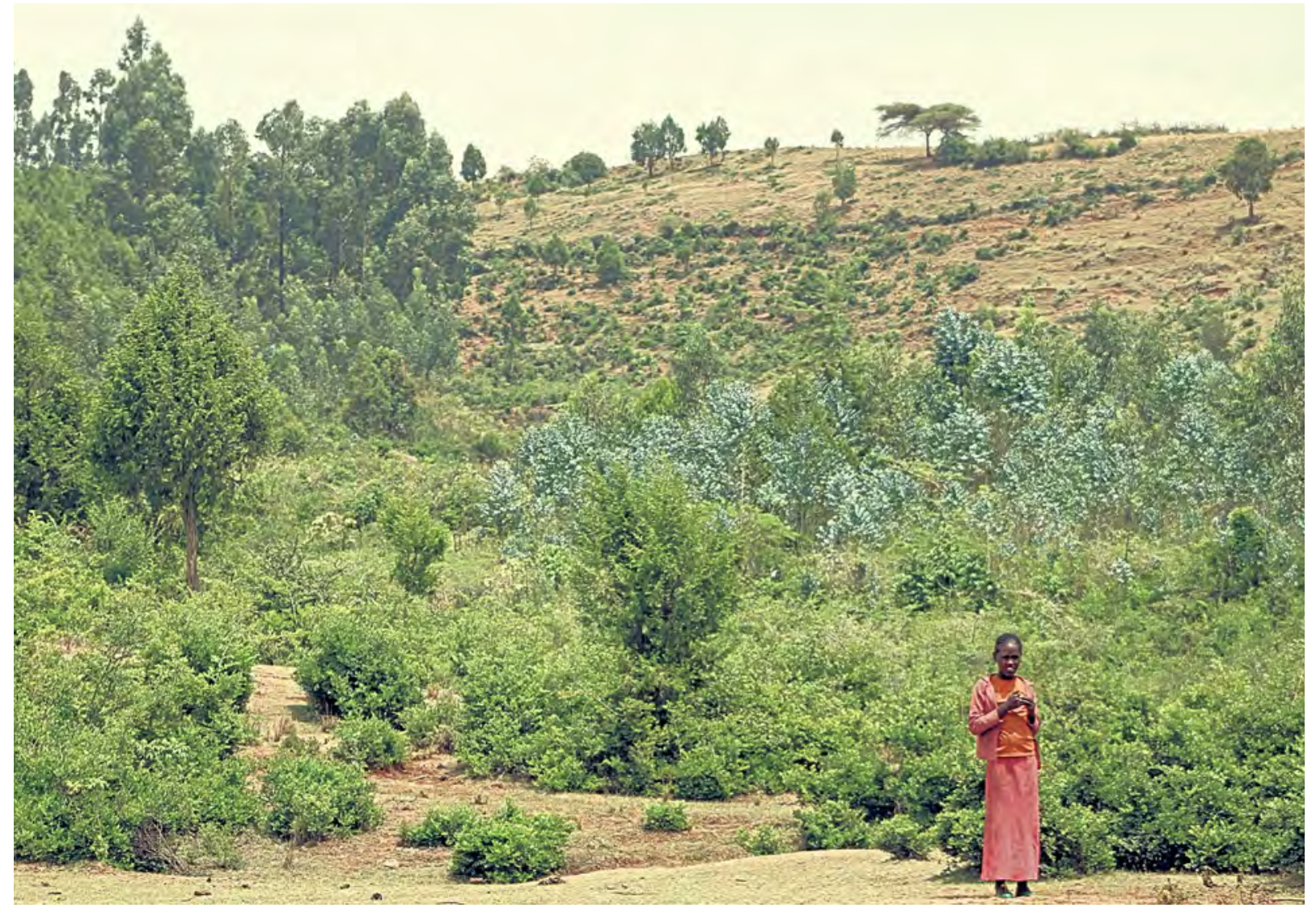

A zona de transição entre terras agrícolas, plantações florestais de transição e floresta nativa de zimbro em Oromia, Etiópia. Foto cedida por Craig Beatty/UICN 


\section{Como é que espécies nativas da paisagem, especialmente} plantas, podem ser incluídas no processo de restauração e qual é a disponibilidade atual de plantas nativas? Há viveiros de plantas disponíveis ou há uma oportunidade de desenvolver viveiros de plantas nativas como parte do processo de restauração?

Em muitas, mas não em todas as intervenções de FLR, pode ser melhor concentrar esforços de restauração em espécies de plantas nativas adaptadas ao ambiente local para obter maior retorno sobre a conservação da biodiversidade e a expansão dos benefícios do serviço ecossistémico para as pessoas. Os funcionários florestais locais, extensionistas e o ecologista-chefe do projeto podem fornecer apoio na seleção de espécies de plantas que se podem concentrar em áreas mistas de espécies nativas, em vez de monoculturas nativas e consorciação com espécies nativas em sistemas agroflorestais ou quebra-ventos, por exemplo. O fornecimento de espécies nativas para restauração pode apresentar os seus próprios desafios, pois o acesso a sementes e mudas nativas pode não ser imediatamente possível a partir de viveiros locais. Essa questão precisa ser considerada no início do processo geral de planeamento do projeto, especialmente porque pode haver oportunidades de emprego na comunidade local através do desenvolvimento de viveiros para cultivar as espécies nativas necessárias para a FLR (um compromisso de longo prazo em muitos casos). Se o plantio mais imediato de uma área for necessário, espécies exóticas podem ser usadas para estabilizar a terra degradada enquanto plantas nativas estão a ser cultivadas, e então pode ser possível substituir a vegetação exótica por espécies nativas o mais rápido possível numa abordagem de alternância ou integrá-las num plano em que se sucedem umas às outras (Tanveer et al., 2017).

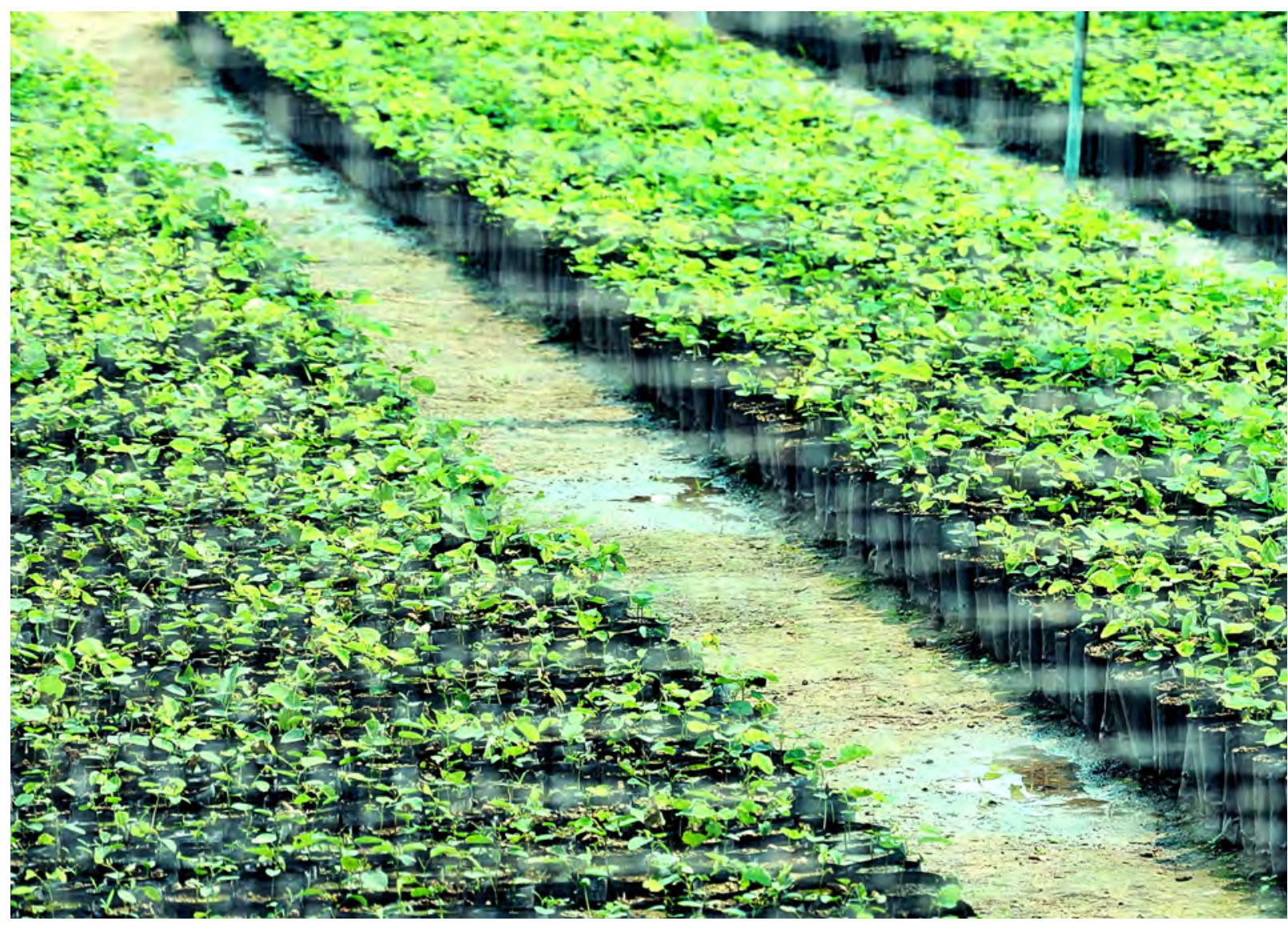

Um viveiro de Siamese Rosewood (Dalbergia cochinchinensis) em Siem Reap, Camboja. Este viveiro estatal fornece mudas para proprietários de terras e escolas sem nenhum custo, e a compra comercial é disponibilizada para aqueles que desejam iniciar uma plantação destas árvores. Uma espécie de alto valor, a Siamese Rosewood pode proporcionar um investimento lucrativo em restauração florestal a longo prazo. Foto cedida por Craig Beatty/UICN 


\section{Como é que a restauração de uma área, bioma ou ecossistema}

causará impacto no valor da biodiversidade de áreas, biomas e ecossistemas (incluindo água doce e marinha) adjacentes ou ligados/associados à paisagem a ser restaurada?

A restauração do habitat no interior de um grande local de projeto terá quase certamente alguns impactos ecológicos ou ambientais sobre a riqueza (ou valor) da biodiversidade de áreas vizinhas, biomas ou ecossistemas. No interior de sistemas terrestres, um impacto imediato será o restabelecimento ou expansão de um tipo de habitat que foi anteriormente perdido, ou muito reduzido, para a área, muitas vezes resultante da pressão anterior de pessoas por terra ou recursos. Embora isso possa ser desejável do ponto de vista da restauração da biodiversidade (conforme resumido nestas diretrizes), é importante que sejam tomados cuidados para pesquisar os habitats no local do projeto antes de iniciar qualquer trabalho de restauração. Sem bons e bem planeados levantamentos da paisagem, existe a possibilidade de que importantes habitats locais, como pradarias naturais ou áreas alagadas, possam ser danificados através de medidas inadequadas. Antes do início de um projeto, é uma boa prática mapear essas áreas e pensar cuidadosamente sobre os impactos que o trabalho extensivo de plantio ou restauração pode ter sobre essas terras (como mudanças nos sistemas hidrológicos). Além dos amplos impactos terrestres da restauração, haverá mudanças adicionais nos sistemas locais de água doce e marinha, geralmente dentro da bacia hidrográfica do projeto de restauração. Como observado, mudanças complicadas nos sistemas hidrológicos podem às vezes ser resultados de mudanças na vegetação circundante - provavelmente a redução do escoamento da água da terra em lagos de água doce, córregos e finalmente em sistemas marinhos, assim como a redução do sedimento erodido de habitats terrestres. Em muitos casos, isso pode levar a um impacto ambiental geral positivo para o sistema hidrológico associado (por exemplo, turbidez reduzida), mas a prospeção dessas mudanças deve ser feita durante o estágio de planeamento.

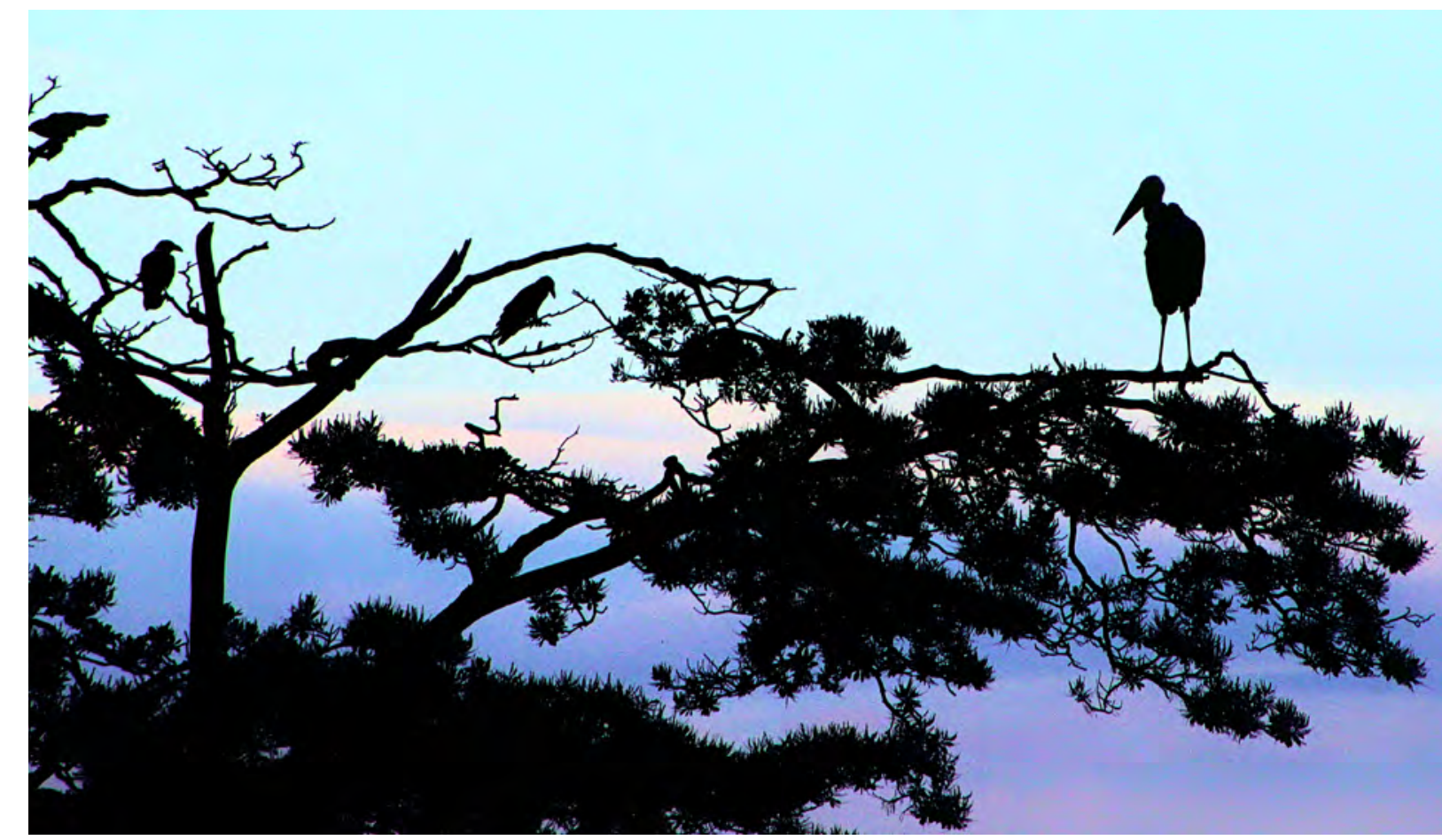

Cegonha de marabu (Leptoptilos crumenifer) e corvos pied (Corvus albus) em Jinja, Uganda. Foto cedida por Craig Beatty/UICN 


\section{Existem espécies individuais (talvez espécies ameaçadas} ou endémicas), reuniões de espécies ou outras unidades de conservação que precisam de consideração especial e acomodação potencial dentro do processo de planeamento?

Os benefícios de incluir diretamente informações sobre a conservação da biodiversidade e as partes interessadas no processo de planeamento superam em muito os custos se estiver claro desde o início que a FLR não se destina principalmente a ser um mecanismo para restauração ecológica integral. Embora a FLR possa não alcançar todos os objetivos da restauração ecológica completa, os envolvidos com a conservação da biodiversidade e a FLR têm uma oportunidade significativa de cooperação para aumentar a produtividade ecológica e apoiar os meios de subsistência. Para os profissionais de biodiversidade, a FLR oferece uma oportunidade de melhorar amplamente as condições das espécies e ecossistemas e reduzir as ameaças e pressões à biodiversidade em uma escala de centenas de milhões de hectares em todo o mundo. Os praticantes da FLR podem obter conhecimento valioso sobre espécies e ecossistemas nas paisagens-alvo, de modo a que as ações de restauração possam ser avaliadas e planeadas dentro de um contexto de ecossistema - aumentando as hipóteses de sucesso na restauração da paisagem.

Tanto a conservação como a restauração têm o potencial de monitorar e comunicar os benefícios de uma abordagem integrada da biodiversidade para as avaliações da FLR. Estes podem incluir relatórios sobre metas e objetivos de desenvolvimento internacional e nacional, mas, mais importante, podem atestar os benefícios que uma abordagem informada sobre a biodiversidade para a FLR pode ter para o bem-estar humano e meios de subsistência a curto e longo prazo.

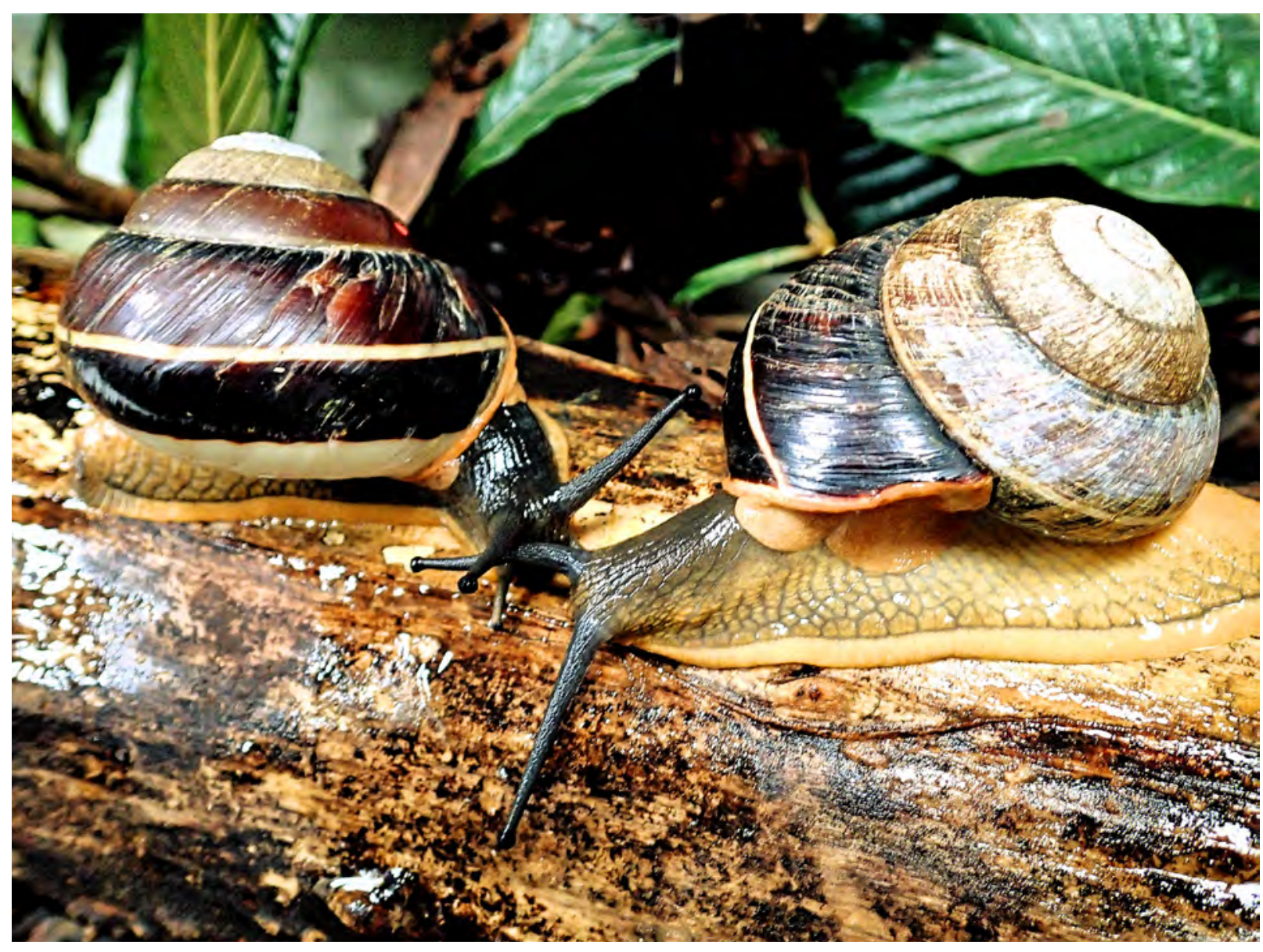

0 Caramujo Gigante Vietnamita (Bertia cambojiensis) restringe-se a apenas uma pequena área no sul do Vietname. Devido à sua grande concha e raridade, encontra-se sob pressão por causa da colheita e de declínios na extensão e na qualidade do habitat. Foto cedida por Paul Pearce-Kelly 


\section{Comunicando a biodiversidade de forma eficaz}

A identificação e avaliação de oportunidades de restauração da paisagem florestal, interação com partes interessadas relevantes, análise de políticas e análise de dados espaciais e benefícios económicos da biodiversidade na secção anterior e no manual da ROAM, levaram, esperançosamente, a uma rede de biodiversidade nacional e internacional de contatos e informações pertinentes sobre FLR e biodiversidade. Além disso, dados espaciais e análises económicas deveriam ter criado dados empíricos sobre a localização e a prioridade dos locais de biodiversidade dentro da área de avaliação. Quando em restauração, essas áreas podem ajudar a aliviar as pressões e ameaças à biodiversidade, aumentar a biodiversidade geral da paisagem a ser restaurada e ajudar a restaurar áreas de alto valor para a biodiversidade que estão atualmente degradadas.

Embora este trabalho esteja completo por enquanto, os resultados precisam ser claramente articulados e comunicados tanto entre a equipa de avaliação, como para o público externo. A comunicação entre a equipa garante que os benefícios para a FLR, através de considerações sobre a biodiversidade, sejam explicitamente incluídos na avaliação e estratégia de oportunidades de restauração da paisagem florestal. A comunicação fora da equipa de avaliação imediata garante que as informações colhidas ou sintetizadas a partir do processo de avaliação, serão incluídas nas políticas e planos relevantes e integradas na implementação da FLR.

A avaliação da biodiversidade para avaliações de restauração da paisagem florestal é uma componente de um processo muito maior. Embora a biodiversidade seja considerada em cada estágio, há marcos importantes dentro do processo de avaliação em que as informações sobre biodiversidade podem ser comunicadas e/ou integradas de forma mais efetiva.

A identificação dos benefícios da biodiversidade como uma componente-chave de qualquer avaliação da FLR deve ser comunicada no início de cada processo. Pode ser que a conservação da biodiversidade não seja um objetivo primário da restauração da paisagem florestal, e isso pode acontecer por razões compreensíveis e práticas. No entanto, se a biodiversidade e o apoio de ecossistemas produtivos são um objetivo declarado da restauração da paisagem florestal, os processos subjacentes que fazem com que a FLR seja bem-sucedida estão enraizados na restauração dos processos biológicos e ecológicos que são realizados pela interação entre as espécies numa paisagem.
A biodiversidade é uma componente de qualquer ação de restauração da paisagem. A inclusão do conhecimento específico sobre biodiversidade é importante no processo de avaliação. Todos os atores devem reconhecer a importância da biodiversidade na FLR. A restauração de paisagens segue muitos caminhos por muitas razões diferentes e frequentemente concorrentes - alguns dos quais seriam prejudicados por uma dependência excessiva da integração de especificidades da biodiversidade. Por exemplo, a seleção de espécies agroflorestais pode ser severamente restringida pelo que os mercados e as condições de cultivo tolerarão e, como tal, a funcionalidade de uma perspectiva de biodiversidade para espécies agroflorestais pode ser restrita.

Ao integrar o conhecimento da biodiversidade no processo de avaliação, o praticante da FLR deve reconhecer quando uma discussão sobre a biodiversidade ajuda a facilitar o processo e quando reduz os objetivos da FLR. No caso de sistemas agroflorestais, embora a biodiversidade nem sempre seja uma parte significativa da escolha dessas espécies, a via de implementação da restauração agroflorestal apresenta um ponto de entrada apropriado para uma discussão sobre a biodiversidade. Como estratégia diversificada implementada na escala da paisagem, a restauração da biodiversidade da paisagem pode ajudar no suporte ao sucesso de intervenções agroflorestais e, em vez de se concentrar na escolha de espécies dentro da intervenção, o praticante de restauração também pode focalizar onde intervenções agroflorestais poderiam interagir e/ou dar apoio à biodiversidade da paisagem. Por outro lado, também pode ser possível avaliar como a restauração da função ecológica numa área pode apoiar a prestação de serviços ecossistémicos noutras áreas.

Durante o processo em $\mathrm{si}$, as informações e conhecimentos sobre biodiversidade podem ser colhidos e comunicados durante o início do projeto, ao se incluírem as partes que estão interessadas e preocupadas com a conservação e restauração da biodiversidade. Durante a parte da análise da avaliação da paisagem, informações e dados sobre biodiversidade podem ser um ponto de partida para análises políticas e institucionais através de uma revisão da EPANB, fontes internacionais e nacionais de dados de biodiversidade e através da avaliação de serviços ecossistémicos e conexões entre espécies e mercados económicos. A fase de análise do processo de avaliação é um momento oportuno para garantir que o papel desempenhado pela biodiversidade na 
consecução dos objetivos da FLR seja claro e apoiado nos dados, ciência e política existentes. Uma vez que a biodiversidade é explicitamente incluída na análise, torna-se muito mais fácil comunicar os resultados de uma avaliação da FLR em termos de ganhos e benefícios da biodiversidade.

A comunicação facilitada do conhecimento sobre biodiversidade gerado a partir do processo de avaliação da paisagem é primordial. Isso significa que a informação sobre a importância da biodiversidade não é apresentada como um fator que pode ser considerado ou não - é a condição última sobre a qual a restauração terá sucesso ou fracassará. Intervenções de restauração, especialmente aquelas em espécies de paisagens pobres e produtivas, que não dão suporte à biodiversidade e à diversidade genética na restauração da produtividade do ecossistema, falham porque as intervenções podem não ser adequadas às ecologias vigentes e aos processos paisagísticos (Lindenmayer et al., 2002; Reynolds et al. 2012).
Isso não quer dizer que os mapas e análises de onde a biodiversidade é especialmente importante para ser levada em consideração não sejam componentes valiosos do processo de avaliação da FLR por si mesmos. Os produtos de dados, o conhecimento gerado e as conexões institucionais entre a biodiversidade e os processos de FLR ajudam a integrar a biodiversidade e a restauração da paisagem florestal. O resultado da comunicação desta informação sobre biodiversidade na equipa de avaliação e para públicos mais amplos será um reconhecimento do papel primordial que a biodiversidade desempenha no sucesso de longo prazo da restauração da paisagem florestal e na integração mais profunda entre conhecimento, ferramentas e capacidades relacionados à biodiversidade num processo já com impacto e significativo.

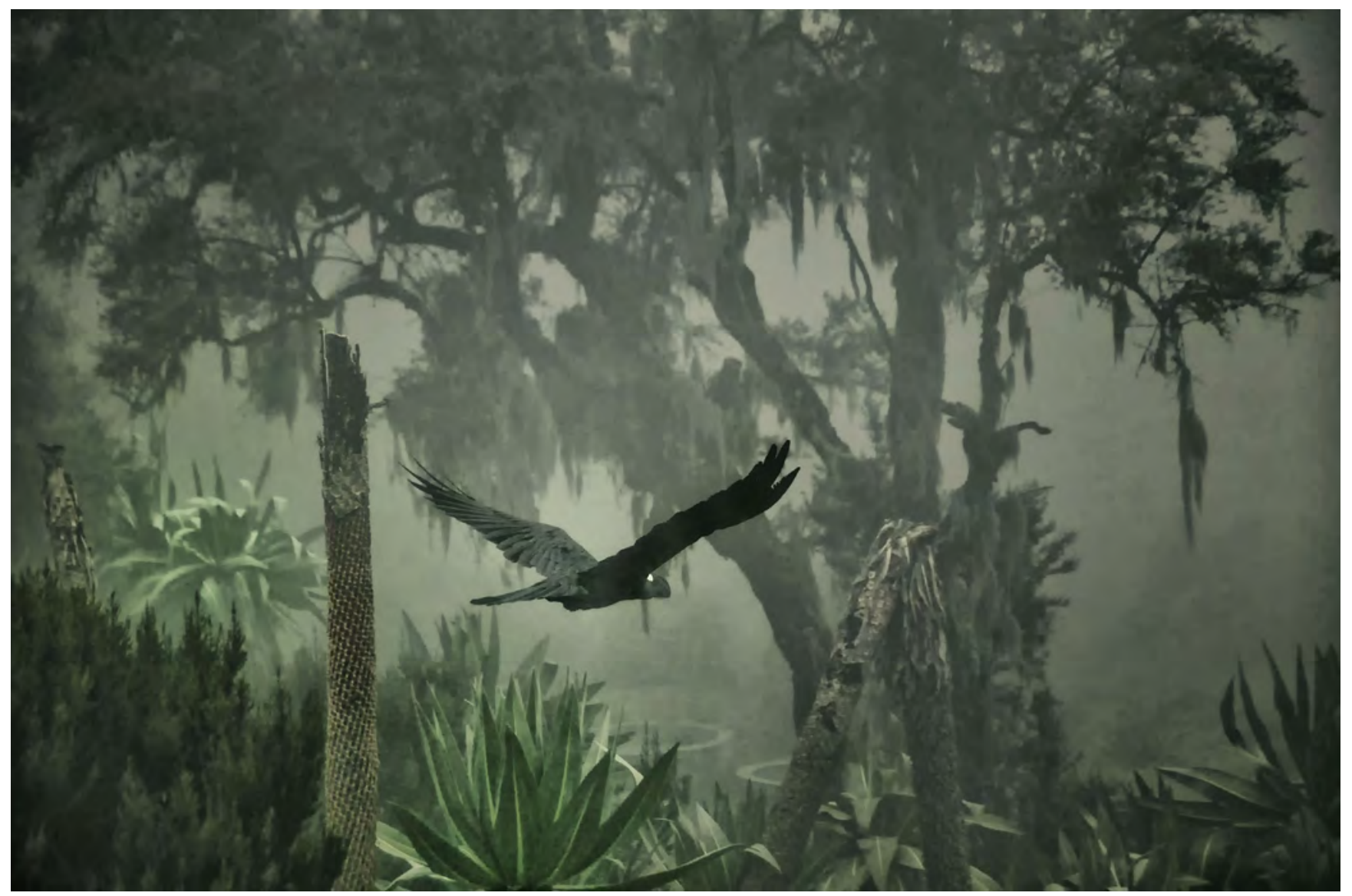

Um corvo vulturino (Corvus crassirostris) nas montanhas de Simien, Etiópia. Foto cedida por Rod Waddington 


\section{Conclusão}

Na prática, a FLR está amplamente preocupada com intervenções que ocorrem em paisagens sob cultivo dominadas pelo homem. Isso significa que a FLR apoia-se fortemente em atividades de restauração como agroflorestamento, agricultura de conservação e outros métodos de restauração baseados na agricultura para aumentar a fertilidade do solo e a produção de alimentos. No entanto, a integração da biodiversidade nativa e nova nessas intervenções é um ponto de entrada único e importante para uma consideração mais substancial dos processos ecológicos na FLR.

\begin{abstract}
A Restauração da Paisagem Florestal continua a emergir como uma ferramenta-chave para melhorar as condições ambientais locais e globais, tanto para as pessoas quanto para a natureza. Espera-se que, em muitos casos, uma consideração ampliada e o uso cuidadoso dos dados de biodiversidade no processo de FLR, levem aos objetivos socioeconómicos e ambientais desejados de todas as atividades de restauração e conservação da paisagem.
\end{abstract}

A restauração bem-sucedida da paisagem florestal, que integra considerações e benefícios à biodiversidade, será fundamental para restaurar a produtividade ecológica de uma paisagem. Estes aumentos na produtividade ecológica são o produto de práticas de paisagem saudáveis e sustentáveis que apoiam a resiliência e a produtividade alimentar e sustentam a biodiversidade. $O$ fato de a restauração da paisagem florestal não ser focada externamente na conservação e restauração da biodiversidade é, talvez, uma das suas forças; as questões de espécies e biodiversidade muitas vezes não conseguem encontrar tração nos processos de tomada de decisões em torno do projeto, planeamento $\mathrm{e}$ financiamento da paisagem, especialmente quando a conservação pode estar em desacordo com as atividades económicas ou industriais.

A biodiversidade é inerente à abordagem de FLR aumentos na produtividade ecológica não podem ser alcançados de forma sustentável sem ganhos na diversidade de espécies e nos benefícios da paisagem que são fornecidos por essa diversidade. No entanto, a maioria das intervenções da FLR, uma vez que ocorrem em terras degradadas e desmatadas, concentram-se em deter e reverter a degradação da paisagem que atualmente está a ser cultivada ou usada por pessoas. A área terrestre disponível em todo o mundo para restauração em terras agrícolas desmatadas ou degradadas é enorme e é, sem dúvida, uma área maior do que a área prática disponível para a restauração ecológica tradicional. Este documento de orientação delineou a importância de considerar genes, espécies e ecossistemas nas avaliações de FLR e nas estratégias de implementação resultantes. Também forneceu uma riqueza de recursos para conectar-se aos profissionais de informação e de biodiversidade e delineou algumas das previsões que são críticas para o levantamento e monitoria do efeito da FLR na biodiversidade e nos serviços ecossistémicos. Também é fundamental a descrição detalhada das fontes de informações sobre biodiversidade que são explícitas na sua conexão com a biodiversidade (por exemplo, Lista Vermelha de Espécies Ameaçadas da UICN e Lista Vermelha de Ecossistemas Ameaçados da UICN) e as conexões implícitas nas políticas de desenvolvimento económico. Procedimentos sugeridos para mapear prioridades de biodiversidade dentro de um processo de avaliação são aqui articulados, juntamente com fontes de dados de biodiversidade espaciais e não espaciais para apoiar este processo de mapeamento. Por fim, estas diretrizes fornecem sugestões e recursos para os praticantes da FLR sobre como este processo de avaliação pode incluir procedimentos de salvaguarda da biodiversidade para ajudar a garantir que a FLR não introduza inadvertidamente reduções na biodiversidade, através de intervenções que possam ser benéficas para a biodiversidade e serviços ecossistémicos em algumas situações, mas prejudicial à biodiversidade noutros.

Estas diretrizes pretendem facilitar uma integração mais ampla do conhecimento sobre a biodiversidade e consideração no processo de avaliação da FLR. Os aumentos na biodiversidade da paisagem continuam a ser um resultado crítico da restauração bemsucedida da paisagem florestal, mas grandes ganhos em biodiversidade e conservação de espécies não são a razão de ser da restauração da paisagem florestal. Os ganhos para a biodiversidade devem ser aumentados para apoiar as pessoas que vivem nas paisagens. Isto não significa negar as incríveis oportunidades de grandes ganhos de biodiversidade e restauração de ecossistemas que podem resultar das atividades de FLR, mas esses objetivos devem ser moderados por uma abordagem intersetorial que restaure iterativamente ecossistemas funcionais para paisagens funcionais.

Como uma das maiores e mais respeitadas autoridades sobre biodiversidade e ecossistemas, a UICN reconhece os impactos potenciais de mudanças na paisagem em larga escala na biodiversidade e nos ecossistemas. A restauração 
da paisagem florestal tem um enorme potencial para apoiar a subsistência humana em conjunto com o aumento da biodiversidade, serviços ecossistémicos e produtividade ecológica em paisagens degradadas. A restauração da paisagem florestal não deve ocorrer em áreas que não são degradadas, obstando assim as áreas de prioridade ou preocupação com a conservação. Onde houver ambiguidade nas definições ou extensão da degradação, o ónus recairá sobre os praticantes da restauração ao utilizarem estas diretrizes para garantir que os ecossistemas nativos não sejam classificados indevidamente como degradados e não apenas apoiar as abordagens de FLR que não causem danos à biodiversidade nativa, mas usar abordagens diversificadas de restauração para aumentar a biodiversidade, especialmente em áreas importantes para espécies e ecossistemas ameaçados. 


\section{Referências}

Anderson, M.G. e Ferree, C.E. (2010). 'Conserving the Stage: Climate Change and the Geophysical Underpinnings of Species Diversity'. PLOS ONE. 5: e11554. doi: 10.1371/journal.pone.0011554.

Arrow, K., Bolin, B., Costanza, R., Dasgupta, P., Folke, C., Holling, C.S., Levin, S., Maler, K.-G., Perrings, C. e Pimentel, D. (1995). 'Economic Growth, Carrying Capacity and the Environment'. Science 268:520-521. https://doi.org/10.1126/ science.268.5210.520

Cardinale, B.J., Duffy, J.E., Gonzalez, A., Hooper, D.U., Perrings, C., Venail, P., Narwani, A., Mace, G.M., Tilman, D., Wardle, D.A., Kinzig, A.P., Daily, G.C., Loreau, M., Grace, J.B., Larigauderie, A., Srivastava, D. e Naeem, S. (2012). 'Biodiversity Loss and its Impact on Humanity'. Nature 486: 59-67. https://doi.org/10.1038/nature11148

De Vitis, M., Abbandonato, H., Dixon, K.W., Laverack, G., Bonomi, C. e Pedrini, S. (2017). 'The European Native Seed Industry: Characterization and Perspectives in Grassland Restoration'. Sustainability 9(10): 1682. https://doi.org/10.3390/ su9101682

FAO (2016). State of the World's Forests (2016). Rome, Italy: FAO

Griscom, B.W., Adams, J., Ellis, P.W., Houghton, R.A., Lomax, G., Miteva, D.A., Schlesinger, W.H., Schoch, D., Siikamaki, J.V., Smith, P., Woodbury, P., Zganjar, C., Blackman, A., Campari, J., Conant, R.T., Delgado, C., Elias, P., Gopalakrishna T., Hamsik, M.R., Herrero, M., Kiesecker, J., Landis, E., Laestadius, L, Leavitt, S.M., Minnemeyer, S., Polasky, S., Potapov, P, Putz, F.E., Sandermann, J. Silvius, M., Wollenberg, E. e Fargione, J. (2017). 'Natural Climate Solutions'. Proceedings of the National Academy of Sciences of the United States of America 114(44): 11645-11650.

Haase, D.L. e Davis, A.S. (2017). 'Developing and Supporting Quality Nursery Facilities and Staff are Necessary to Meet Global Forest and Landscape Restoration Needs'. Reforesta 4: 69-93.

Hatton, T.J. e Nulsen, R.A. (1999). 'Towards Achieving Functional Ecosystem Mimicry with respect to Water Cycling in Southern Australian Agriculture'. Agroforestry Systems 45(1-3): 203- 214 https:// doi.org/10.1023/A:1006215620243

Herrera, D., Ellis, E., Fisher, B., Golden, C.D., Johnson, K., Mulligan, M., Pfaff, A., Treuer, T. e Ricketts, T.H. (2018). 'Upstream Watershed Condition Predicts Rural Children's Health Across 35 Developing Countries'. Nature Communications 8:811. https://doi.org/10.1038/s41467-017-00775-2
Hooper, D.U., Chapin, F.S., Ewel, J.J., Hector, A., Inchausti, P., Lavorel S., Lawton, J.H., Lodge, D.M., Loreau, M., Naeem, S., Schmid, B., Setala, H., Symstad, A.J., Vandermeer, J. e Wardle, D.A. (2005). 'Effects of Biodiversity on Ecosystem Functioning: A Consensus of Current Knowledge'. Ecological Monographs 75(1): 3-35. https://doi. org/10.1890/04-0922

Hooper, D.U., Adair, E.C., Cardinale, B.J., Byrnes, J.E.K., Hungate, B.A., Matulich, K.L., Gonzalez, A., Duffy, J.E., Gamfeldt, L. e O'Connor, M.I. (2012). 'A Global Synthesis Reveals Biodiversity Loss as a Major Driver of Ecosystem Change'. Nature 486: 105.

Jalonen, R., Valette, M., Boshier, D., Duminil, J., Thomas, E. (2017). 'Forest and Landscape Restoration Severely Constrained by a Lack of Attention to the Quantity and Quality of Tree Seed: Insights from a Global Survey'. Conservation Letters e12424. https://doi.org/10.1111/ conl.12424

The KBA Partnership (2018) Guidelines on Business and KBAs: Managing Risk to Biodiversity. Gland: UICN. 24pp, 2018. https://doi.org/10.2305/UICN. CH.2018.05.en

Kumar, P., Brondizio, E., Gatzweiler, F., Gowdy, J., de Groot, D., Pascual, U., Reyers, B. e Sukhdev, P. (2013). 'The Economics of Ecosystem Services: From Local Analysis to National Policies'. Current Opinions on Environment Sustainability 5: 78-86. https://doi.org/10.1016/j.cosust.2013.02.001

Lamb, D. (2014). Large Scale Forest Restoration. London: Routledge.

Larsen, F.W., Turner, W.R. e Brooks, T.M. (2012). 'Conserving Critical Sites for Biodiversity Provides Disproportionate Benefits to People'. PLOS ONE 7(5): e36971. https://doi.org/10.1371/ journal.pone.0036971

Lindenmayer, D.B., Manning, A.D., Smith, P.L., Possingham, H.P., Fischer, J., Oliver, I. e McCarthy, M.A. (2002). 'The Focal-Species Approach and Landscape Restoration: A Critique'. Conservation Biology 16(2): 338-345. https://doi.org/10.1046/ j.1523-1739.2002.00450.x

Mace, G.M., Baillie, J., Masundire, H., Ricketts, T.H., Brooks, T.M., Hoffmann, M., Stuart, S.N., Balmford, A., Purvis, A., Reyers, B., Wang, J., Revenga, C., Kennedy, E.T., Naeem, S., Alkemade, R., Allnutt, T., Bakarr, M., Bond, W., Chanson, J., Cox, N., Fonseca, G., Hilton-Taylor, C., Loucks, C., Rodrigues, A., Sechrest, W., Stattersfield, A.J., van Rensburg, B. e Whiteman, C. 2005. 'Biodiversity'. In: Millennium Ecosystem 
Assessment: Current State and Trends: Findings of the Condition and Trends Working Group. Ecosystems and Human Well-Being. Washington DC: Island Press.

Maginnis, S. e Jackson, W. (2002). Restoring Forest Landscapes: Forest Landscape Restoration Aims to Re-Establish Ecological Integrity and Enhanced Human Well-Being in Degraded Forest Landscapes. Gland, Suíça: UICN.

Naumann, S., Kaphengst, T., McFarland, K. e Stadler, J. (2014). Nature-Based Approaches for Climate Change Mitigation and Adaptation. Bonn, Alemanha: German Federal Agency for Nature Conservation.

Oliver, T.H., Heard, M.S, Isaac, N.J.B., Roy, D.B., Procter, D., Eigenbrod, F., Freckleton, R., Hector, A., Orme, D.L., Petchey, O.L., Proença, V., Raffaelli, D., Suttle, K.B., Mace, G.M., MartínLópez, B., Woodcock, B.A. e Bullock, J.M. (2015a.) Biodiversity e Resilience of Ecosystem Functions. Trends in Ecology \& Evolution 30(11): 673-684. https://doi.org/10.1016/j.tree.2015.08.009

Oliver, T.H., Isaac, N.J.B., August, T.A., Woodcock, B.A., Roy, D.B. e Bullock, J.M. (2015b). 'Declining Resilience of Ecosystem Functions under Biodiversity Loss'. Nature Communications 6: 10122. https://doi.org/10.1038/ncomms10122

Orgiazzi, A., Bardgett, R.D., Barrios, E., BehanPelletier, V., Briones, M.J.I., Chotte, J.-L., De Deyn, G.B., Eggleton, P., Fierer, N., Fraser, T., Hedlund, K., Jeffery, S., Johnson, N.C., Kandler, E., Kaneko, N., Lavelle, P., Lomanceau, P., Miko, L., Montanarella, L., Moreira, F.M.S., Ramirez, K.S., Scheu, S., Singh, B.K., Six, J., Van der Putton, W.H. e Wall, D.H. (2016). Global Soil Biodiversity Atlas. Luxembourg: European Commission publications, Office of the European Union.

Pressey, R.L., Cabeza, M., Watts, M.E., Cowling, R.M. e Wilson, K.A. (2007). 'Conservation planning in a changing world'. Trends in Ecology \& Evolution. 22: 583-592. doi: 10.1016/j.tree.2007.10.001

Pringle, C.M. (2001). 'Hydrological Connectivity and the Management of Biological Reserves: A Global Perspective'. Ecological Applications 11(4): 981-998. https://doi.org/10.1890/10510761(2001)011[0981:HCATMO]2.0.CO;2

Reusch, T.B.H., Ehlers, A., Hammerli, A. e Worm, B. (2005). 'Ecosystem Recovery after Climatic Extremes Enhanced by Genotypic Diversity'. Proceedings of the National Academy of Sciences of the United States of America 102: 2826. https:// doi.org/10.1073/pnas.0500008102

Reynolds, L.K., McGlathery, K.J. e Waycott, M. (2012). 'Genetic Diversity Enhances Restoration Success by Augmenting Ecosystem Services'. PLOS ONE 7(6): e38897. https://doi.org/10.1371/journal. pone.0038397
Rietbergen-McCracken, J., Maginnis, S. e Sarre, A. (eds.). (2007). The Forest Landscape Restoration Handbook. London: Earthscan.

Secretaria da Convenção sobre Diversidade Biológica (2010). Linking Biodiversity Conservation and Poverty Alleviation: A State of Knowledge Review. CBD Technical Series No. 55.

Secretaria da Convenção sobre Diversidade Biológica (2013). Water and Biodiversity: Natural Solutions for Water Security. Montreal, Canadá.

Sunderland, T.C.H. (2011). 'Food Security: Why is Biodiversity Important'? International Forestry Review 13(3): 265-274. https://doi. org/10.1505/146554811798293908

Metas de Desenvolvimento Sustentável. (2015). UN General Assembly Seventieth Session Agenda Item 15 and 116: Transforming our World: The 2030 Agenda for Sustainable Development. AV RES/70/1.

Tanveer, M., Anjum, S.A., Hussain, S., Cerda, A. e Ashraf, U. (2017). 'Relay Cropping as a Sustainable Approach: Problems and Opportunities for Sustainable Crop Production'. Environmental Science and Pollution Research 24(8): 6973-6988. https://doi.org/10.1007/s11356-017-8371-4

Thomas, C.D., Cameron, A., Green, R.E., Bakkenes, M., Beaumont, L.J., Collingham, Y.C., Erasmus, B.F., De Sigueira, M.F., Grainger, A., Hannah, L., Hughes, L., Huntley, B., Van Jaarsveld, A.S., Midgley, G.F., Miles, L, Ortega-Huerta, M.A., Peterson, A.T., Phillips, O.L. e Williams, S.E. (2004). 'Extinction Risk from Climate Change'. Nature 427(6970): 145-148. https://doi. org/10.1038/nature02121

UICN 2017. The UICN Red List of Threatened Species. Version 2017-1. <http://www.iucnredlist.org>. Accessed on 12 May 2017.

UICN e WRI. (2014). A Guide to the Restoration Opportunities Assessment Methodology: Assessing Forest Landscape Restoration Opportunities at the National or Sub-National Level. Working Paper. Gland, Suíça: UICN.

UICN/CSE 2013. Guidelines for Reintroductions and Other Conservation Translocations. Version 1.0. Gland, Switzerland: UICN.

Urzedo, D., Vidal, E., Sills, E., Pina-Rodrigues, F., e Junqueira, R. (2016). 'Tropical Forest Seeds in the Household Economy: Effects of Market Participation among Three Sociocultural Groups in the Upper Xingu Region of the Brazilian Amazon'. Environmental Conservation 43(1): 1323. https://doi.org/10.1017/S0376892915000247

Vayreda, J., Martinez-Vilalta, J., Gracia, M. e Rotana, J. (2012). 'Recent Climate Changes Interact with Stand Structure and Management to Determine Changes in Tree Carbon Stocks in Spanish Forests'. Global Change Biology 18: 
1028-1041. https://doi.org/10.1111/j.13652486.2011.02606.x

Vernooy, R., Bessette, G., Rudebjer,P. e Otieno G. (eds) (2016). 'Resource box for resilient seed systems: handbook.' Bioversity International, Roma, Itália.

Walker, B., Salt, D. e Reid, W. (2006). Resilience Thinking: Sustaining People and Ecosystems in a Changing World. Washington DC: Island Press.

Waller, N.L., Gynther, I.C., Freeman, A.B., Lavery, T.H. e Leung, L.K.-P. (2013). 'The Bramble Cay Melomys Melomys rubicola (Rodentia: Muridae): A First Mammalian Extinction Caused by HumanInduced Climate Change'? Wildlife Research 44(1): 9-21. https://doi.org/10.1071/WR16157

Wetzel, F.T., Boissmann, H., Penn, D.J. e Jotz, W. (2013). 'Vulnerability of Terrestrial Island
Vertebrates to Projected Sea Level Rise'. Global Change Biology 19: 2058-2070. https://doi. org/10.1111/gcb.12185

World Conservation Monitoring Centre. (1992). Global Biodiversity: Status of the Earth's Living Resources. Londres: Chapman \& Hall.

Wunder, S., Angelsen, A. e Belcher, B. (2014). 'Forests, Livelihoods, and Conservation: Broadening the Empirical Base'. World Development 64 (Supplement 1): S1-S11. https://doi. org/10.1016/j.worlddev.2014.03.007

Young, T.P. (2000) 'Restoration Ecology and Conservation Biology'. Biological Conservation 92: 73-83. https://doi.org/10.1016/S00063207(99)00057-9 


\section{Anexo 1 Elementos de uma EPANB}

As estratégias e planos de ação nacionais para a biodiversidade estão repletas de informações úteis para avaliações de oportunidades de restauração da paisagem florestal e contêm grande parte das informações necessárias para garantir que a FLR esteja alinhada aos compromissos nacionais da Convenção sobre Diversidade Biológica. É importante ressaltar que as EPANB têm uma estrutura consistente que permite que essas informações sejam encontradas com relativa facilidade, e a maioria dos países usou esta estrutura para definir metas nacionais representativas que ajudam a alcançar os objetivos de biodiversidade estabelecidos pela CDB.

Nessas EPANB, normalmente há auditorias da posição ocupada e da tendência da biodiversidade nacional. Estas são geralmente voltadas para o estado de conservação de espécies de interesse (conforme definido pela Lista Vermelha de Espécies Ameaçadas da UICN ou Listas Vermelhas Nacionais) e tendências na cobertura geográfica de áreas protegidas. As descrições dessas métricas de biodiversidade formam as bases de referência a partir das quais as estratégias de conservação da biodiversidade são medidas e informam a maioria dos países que apresentam relatórios à CDB.

Além disso, as EPANB contêm uma quantidade significativa de relatórios sobre a legislação nacional sobre biodiversidade. Em muitos casos, essa legislação refere-se ao estabelecimento e à manutenção de áreas protegidas e atividades de conservação da vida selvagem, mas inclui cada vez mais aplicações legislativas da biodiversidade em setores onde a biodiversidade pode não ser um objetivo primário, mas que depende da biodiversidade (por exemplo, agricultura).

Combinadas com informações sobre estratégias para financiar a implementação desses planos de ação, as EPANB fornecem as informações que pretendem traduzir as avaliações da biodiversidade à escala nacional em estratégias mensuráveis e acionáveis para a conservação da biodiversidade no apoio à missão da CDB.

\section{Parceria para Indicadores de Biodiversidade} https://www.bipindicators.net/

\section{EPANB da CBD}

https://www.cbd.int/nbsap/
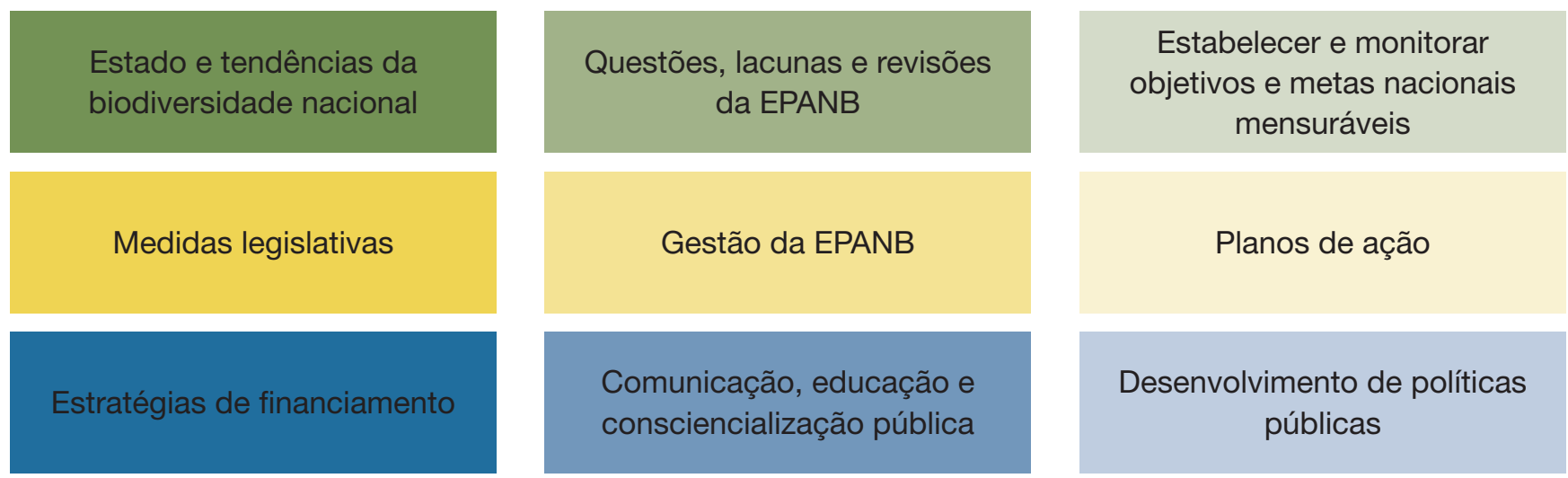

Adaptado de: O Processo de planeamento da Biodiversidade: Como Preparar e Atualizar uma Estratégia Nacional de Biodiversidade e Plano de Ação (CDB, 2007) 


\section{Esboço indicativo de uma EPANB}

\section{INTRODUÇÃO}

1. Valores da biodiversidade e serviços ecossistémicos no país e a sua contribuição para o bem-estar humano

2. Causas e consequências da perda de biodiversidade

3. Estrutura constitucional, legal e institucional

4. Lições aprendidas da(s) EPANB(s) anterior(es) e do processo de desenvolvimento da EPANB atualizada

II. ESTRATÉGIA NACIONAL DE BIODIVERSIDADE: PRINCÍPIOS, PRIORIDADES E METAS
5. Visão de longo prazo
6. Princípios que regem a estratégia
7. Principais objetivos ou áreas prioritárias
8. Metas nacionais

III. PLANO DE AÇÃO NACIONAL

9. Ações nacionais para alcançar a estratégia, com marcos

10. Aplicação da EPANB para entidades subnacionais

11. Ação setorial

IV. PLANOS DE IMPLEMENTAÇÃO

12. Planear o desenvolvimento de capacidades para a implementação da EPANB, incluindo uma avaliação de necessidades tecnológicas

13. Estratégia de comunicação e divulgação para a EPANB

14. Planear a mobilização de recursos para a implementação da EPANB

15. Institucional: monitoria e relatórios

16. Estruturas nacionais de coordenação

17. Mecanismo da câmara de compensação

V. MONITORIA e AVALIAÇÃO

*adaptado de CBD EPANB Training package Versão 2.1 



\section{UICN}

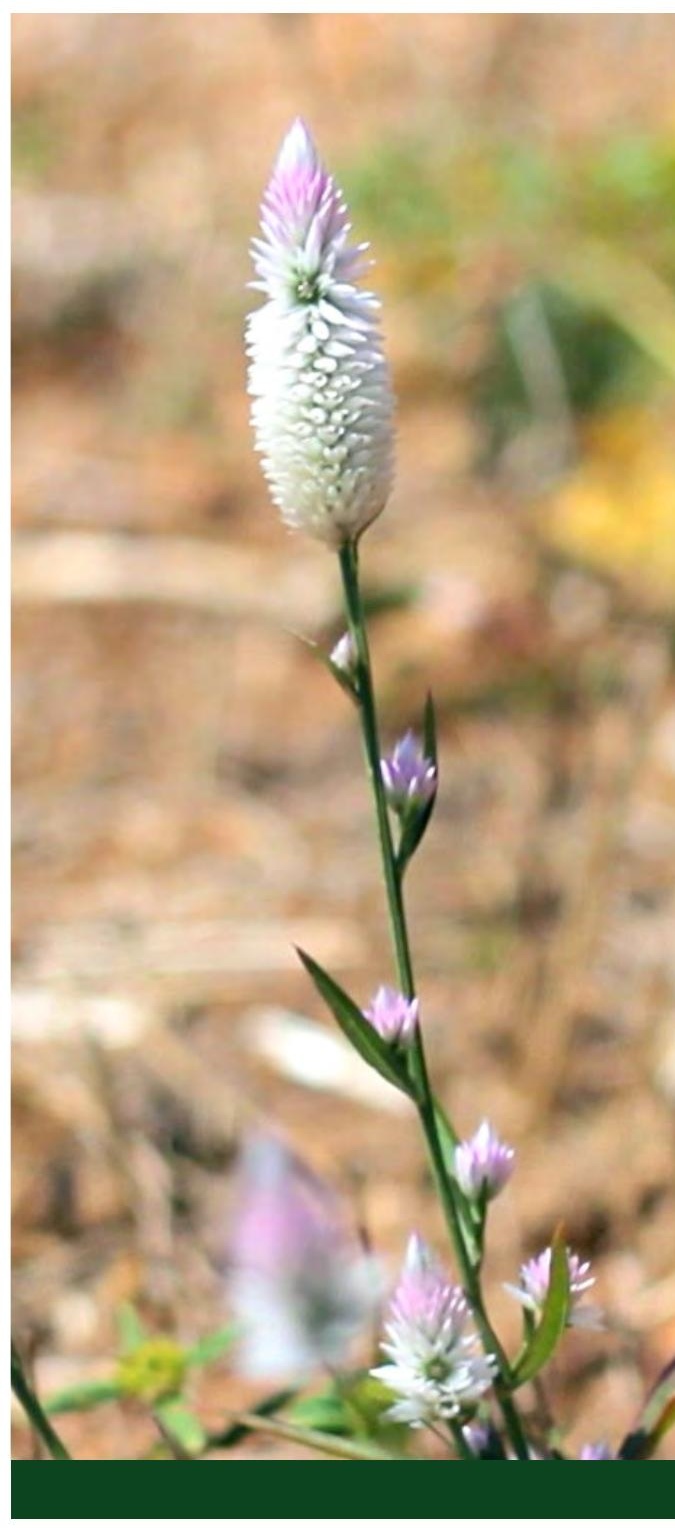

União Internacional para a Conservação da Natureza

SEDE MUNDIAL

Rue Mauverney 28

1196 Gland, Suíça

Tel: +4122 9990000

Fax: +41 229990002

www.iucn.org 